\title{
Agricultural Pesticide Applications and Observed Concentrations in Surface Waters from Four Drainage Basins in the Central Columbia Plateau, Washington and Idaho, 1993-94
}

By Richard J. Wagner, James C. Ebbert, Lonna M. Roberts, and Sarah J. Ryker

U.S. GEOLOGICAL SURVEY

Water-Resources Investigations Report 95-4285 


\section{U.S. DEPARTMENT OF THE INTERIOR \\ BRUCE BABBITT, Secretary}

U.S. GEOLOGICAL SURVEY

Gordon P. Eaton, Director

Any use of trade, product, or firm names is for descriptive purposes only and does not imply endorsement by the U.S. Geological Survey.

For additional information write to:

Copies of this report may be purchased from:

District Chief

U.S. Geological Survey

1201 Pacific Avenue, Suite 600

Tacoma, Washington 98402
U.S. Geological Survey

Earth Science Information Center

Open-File Reports Section

Box 25286, MS 517

Denver Federal Center

Denver, CO 80225

Information regarding the National Water-Quality Assessment (NAWQA) Program is available on the Internet via the World Wide Web. You may connect to the NAWQA Home Page using the Universal Resource Locator (URL) at:

<URL:http:/ / wwwrvares.er.usgs.gov/nawqa/nawqa_home.html> 


\section{FOREWORD}

The mission of the U.S. Geological Survey (USGS) is to assess the quantity and quality of the earth resources of the Nation and to provide information that will assist resource managers and policymakers at Federal, State, and local levels in making sound decisions. Assessment of water-quality conditions and trends is an important part of this overall mission.

One of the greatest challenges faced by waterresources scientists is acquiring reliable information that will guide the use and protection of the Nation's water resources. That challenge is being addressed by Federal, State, interstate, and local water-resource agencies and by many academic institutions. These organizations are collecting water-quality data for a host of purposes that include: compliance with permits and water-supply standards; development of remediation plans for a specific contamination problem; operational decisions on industrial, wastewater, or water-supply facilities; and research on factors that affect water quality. An additional need for water-quality information is to provide a basis on which regional and national-level policy decisions can be based. Wise decisions must be based on sound information. As a society we need to know whether certain types of water-quality problems are isolated or ubiquitous, whether there are significant differences in conditions among regions, whether the conditions are changing over time, and why these conditions change from place to place and over time. The information can be used to help determine the efficacy of existing water-quality policies and to help analysts determine the need for and likely consequences of new policies.

To address these needs, the Congress appropriated funds in 1986 for the USGS to begin a pilot program in seven project areas to develop and refine the National Water-Quality Assessment (NAWQA) Program. In 1991, the USGS began full implementation of the program. The NAWQA Program builds upon an existing base of waterquality studies of the USGS, as well as those of other Federal, State, and local agencies. The objectives of the NAWQA Program are to:
-Describe current water-quality conditions for a large part of the Nation's freshwater streams, rivers, and aquifers.

-Describe how water quality is changing over time.

-Improve understanding of the primary natural and human factors that affect water-quality conditions.

This information will help support the development and evaluation of management, regulatory, and monitoring decisions by other Federal, State, and local agencies to protect, use, and enhance water resources.

The goals of the NAWQA Program are being achieved through ongoing and proposed investigations of 60 of the Nation's most important river basins and aquifer systems, which are referred to as study units. These study units are distributed throughout the Nation and cover a diversity of hydrogeologic settings. More than two-thirds of the Nation's freshwater use occurs within the 60 study units and more than two-thirds of the people served by public water-supply systems live within their boundaries.

National synthesis of data analysis, based on aggregation of comparable information obtained from the study units, is a major component of the program. This effort focuses on selected water-quality topics using nationally consistent information. Comparative studies will explain differences and similarities in observed water-quality conditions among study areas and will identify changes and trends and their causes. The first topics addressed by the national synthesis are pesticides, nutrients, volatile organic compounds, and aquatic biology. Discussions on these and other water-quality topics will be published in periodic summaries of the quality of the Nation's ground and surface water as the information becomes available.

This report is an element of the comprehensive body of information developed as part of the NAWQA Program. The program depends heavily on the advice, cooperation, and information from many Federal, State, interstate, Tribal, and local agencies and the public. The assistance and suggestions of all are greatly appreciated.

Robert M. Hirsch 


\section{CONTENTS}

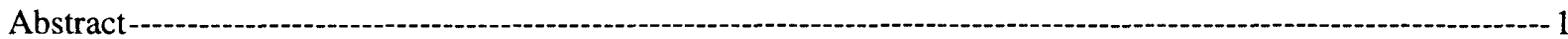

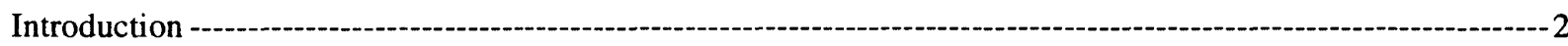

Purpose and scope---

Description of the study unit--

Drainage basins in the irrigated agricultural areas--

Drainage basins in the dryland agricultural areas--

Methods ---o-

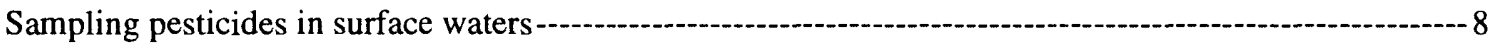

Field procedures --- 8

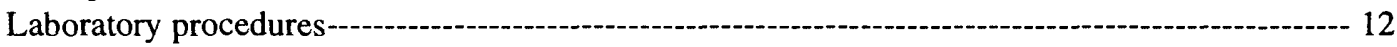

Results of quality-control samples - 12

Pesticide use data--.--on 13

Concentrations of pesticides and pesticide-application data --on 14

Irrigated agricultural drainage basins -

Dryland agricultural drainage basins -

Comparison of irrigated and dryland agricultural areas-a- 37

Selected references-- 45

Appendixes--- 47

\section{FIGURES}

1. Map showing locations of drainage basins of four surface-water sites sampled for pesticides in the Central Columbia Plateau, Washington and Idaho---

2. Map showing land use and subunits in the Central Columbia Plateau, Washington and Idaho-------------5

3. Graphs showing pesticide concentrations and corresponding streamflows at the two surface-water sites located in irrigated agricultural areas and reported periods of pesticide applications in the contributing drainage basins in the Central Columbia Plateau, Washington ------ 24

4. Graphs showing pesticide concentrations and corresponding streamflows at the two surface-water sites located in dryland agricultural areas and reported periods of pesticide applications in the contributing drainage basins of the Central Columbia Plateau, Washington and Idaho

\section{TABLES}

1. Physical and land-use characteristics of four drainage basins sampled for pesticides in the

Central Columbia Plateau, Washington and Idaho

2. Crop acreages in four drainage basins sampled for pesticides in the Central Columbia Plateau, Washington and Idaho --- 7

3. Pesticide target analytes, method detection limits, drinking water standards, and aquatic-life criteria--

4. Maximum concentrations and numbers of detections of pesticides at each and all four surface-water sites in the Central Columbia Plateau, Washington and Idaho-

5. Amounts of pesticides applied to cropland and the number of detections of target analytes in four drainage basins in the Central Columbia Plateau, Washington and Idaho-----------------.- 17

6. Summary of pesticide concentrations from two surface-water sites located in irrigated

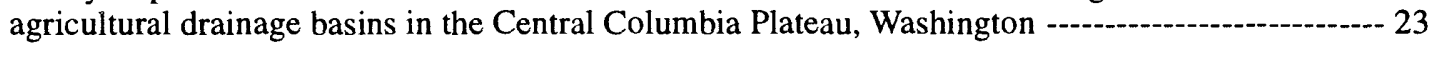

7. Summary of pesticide concentrations from two surface-water sites located in dryland

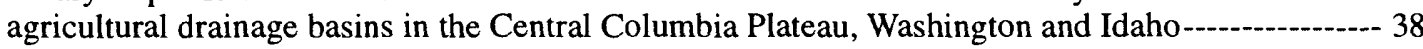

A1. Concentrations and precision data for replicate samples with pesticide detections - -

A2. Summary of recoveries from field-matrix and laboratory-reagent-spike pesticide analyses -------------- 48 


\section{CONVERSION FACTORS AND VERTICAL DATUM}

\begin{tabular}{|c|c|c|}
\hline Multiply & By & To obtain \\
\hline \multicolumn{3}{|c|}{ International system units to inch-pound units } \\
\hline microgram $(\mu \mathrm{g})$ & $3.53 \times 10^{-8}$ & ounce \\
\hline micrometer $(\mu \mathrm{m})$ & $3.937 \times 10^{-5}$ & inch \\
\hline liter (L) & 0.296 & gallon \\
\hline \multicolumn{3}{|c|}{ Inch-pound units to international system units } \\
\hline inch (in.) & 25.4 & millimeter \\
\hline foot $(\mathrm{ft})$ & 0.3048 & meter \\
\hline mile (mi) & 1.609 & kilometer \\
\hline acre & $4.046 \times 10^{-3}$ & square kilometer \\
\hline square mile $\left(\mathrm{mi}^{2}\right)$ & 2.590 & square kilometer \\
\hline cubic foot per second $\left(\mathrm{ft}^{3} / \mathrm{s}\right)$ & 0.02832 & meter per second \\
\hline pound (lb) & 0.4536 & kilogram \\
\hline pound per year $(\mathrm{lb} / \mathrm{yr})$ & 0.4536 & kilogram per year \\
\hline
\end{tabular}

Temperature: To correct temperature given in this report in degrees Celsius $\left({ }^{\circ} \mathrm{C}\right)$, to degrees Fahrenheit $\left({ }^{\circ} \mathrm{F}\right)$, use the following equation: ${ }^{\circ} \mathrm{F}=1.8 \times{ }^{\circ} \mathrm{C}+32$.

Sea Level: In this report "sea level" refers to the National Geodetic Vertical Datum of 1929 (NGVD of 1929)-a geodetic datum derived from a general adjustment of the first-order level nets of both the United States and Canada, formerly called Sea Level Datum of 1929.

\section{Abbreviations:}

$\mu \mathrm{m} \quad$ micrometer

L liter

$\mu \mathrm{g} / \mathrm{L} \quad$ microgram per liter

\section{Acronyms:}

$\begin{array}{ll}\text { USGS } & \text { U.S. Geological Survey } \\ \text { GC/MS } & \text { gas chromatography/mass spectrometry } \\ \text { HPLC } & \text { high-performance liquid chromatography } \\ \text { NA.WQA } & \text { National Water-Quality Assesment Program } \\ \text { NWQL } & \text { National Water Quality Laboratory } \\ \text { SPE } & \text { solid-phase extraction } \\ \text { GIRAS } & \text { Geographic Information and Analysis System } \\ \text { GIS } & \text { geographic information system } \\ \text { USEPA } & \text { U. S. Environmental Protection Agency } \\ \text { MCL } & \text { Maximum Contaminant Level } \\ \text { MDL } & \text { method detection limit }\end{array}$




\title{
Agricultural Pesticide Applications and Observed Concentrations in Surface Waters from Four Drainage Basins in the Central Columbia Plateau, Washington and Idaho, 1993-94
}

\author{
By Richard J. Wagner, James C. Ebbert, Lonna M. Roberts, and Sarah J. Ryker
}

\begin{abstract}
As part of the U.S. Geological Survey's National Water-Quality Assessment Program, the use and occurrence of agricultural pesticides were investigated in four drainage basins--two dominated by irrigated agriculture and two by dryland agriculture--in the Central Columbia Plateau of eastern Washington. For this study, 85 pesticides or pesticide metabolites were selected for analysis from a list of nearly 400 compounds commonly used in the United States. Pesticide-use data included estimates of the total quantity of herbicides, insecticides, and fungicides applied to croplands in each of the four drainage basins and reported times of application for selected pesticides. Pesticide-occurrence data included concentrations of pesticides in samples collected at one surface-water site at or near the outflow of each of the four drainage basins, where surface waters were sampled one to five times a month from March 1993 through May 1994. Of the 85 pesticides or pesticide metabolites targeted for analysis, a total of 45 different compounds were detected in samples from the four sites, ranging in concentration from at or near the limit of detection (as low as 0.001 microgram per liter) to a maximum of 8.1 micrograms per liter. None of the concentrations of pesticides exceeded the U.S. Environmental Protection Agency (USEPA) drinking water standards, but concentrations of five pesticides exceeded the USEPA freshwater-chronic criteria for the protection of aquatic life.
\end{abstract}

Fourty-one different pesticides or pesticide metabolites were detected in surface waters sampled at the two sites representing irrigated agriculture drainage basins. The herbicides atrazine, DCPA, and EPTC were detected most frequently at the two sampling sites. Not all pesticides that were applied were detected, however. For example, disulfoton, phorate, and methyl parathion accounted for 15 percent of the insecticides applied in the two irrigated drainage basins, yet none of these pesticides were detected in samples from the two irrigated-agricultural sites. Concentrations of pesticides found in surface waters at the two sites representing irrigated agriculture did not exceed drinking water standards, but some concentrations of the insecticides carbaryl, chlorpyrifos, diazinon, and azinphos-methyl exceeded the freshwaterchronic criteria for the protection of aquatic life.

Twenty-three different pesticides or pesticide metabolites were detected in samples from the two sites representing dryland agricultural drainage basins. Herbicides were the type of pesticides most heavily applied in these drainage basins, and the herbicides atrazine, triallate, and simazine were detected most frequently in samples. Some herbicides, for example triallate in the Palouse River drainage basin, were both heavily applied and frequently detected. Others, like atrazine and simazine, were not typically applied to cropland, but were frequently detected in surface-water samples. Several insecticides (Lindane, ethoprop, carbaryl, and azinphos-methyl) were detected in samples from the two sites, although they were not reported as commonly applied to croplands in the dryland agricultural drainage basins. Concentrations of pesticides found in surface waters at the two sites did not exceed drinking water guidelines, but concentrations of the insecticides diazinon and azinphos-methyl and the herbicide triallate exceeded freshwater-chronic criteria for the protection of aquatic life. 


\section{INTRODUCTION}

The Central Columbia Plateau study unit is 1 of 60 study units being investigated by the National WaterQuality Assessment (NAWQA) Program of the U.S. Geological Survey (Hirsch and others, 1988; Leahy and others, 1990). The goals of NAWQA are to describe the status and trends in the quality of the Nation's ground- and surface-water resources and to gain a better understanding of the natural and human factors that affect the quality of water resources. The 60 study units, which are distributed throughout the Nation, contribute to the overall goals of NAWQA (Gilliom and others, 1995) by providing waterquality information that is relevant to the study unit and that can be used in combination with information from other study units to assess water quality at regional and National scales.

Because agriculture is the dominant land use in the Central Columbia Plateau study unit, the investigation focused on examining the relation between agricultural land uses and water quality. One aspect of that relation is the question of how pesticide use affects surface- and ground-water resources. The presence of pesticides in water is a concern if concentrations exceed drinking-water standards or are at levels that may adversely affect aquatic life. Previous studies (Washington State Department of Social and Health Services, 1975, 1976, 1977, 1978, 1979; Davis, 1993) have established that pesticides are sometimes present in surface water of the Central Columbia Plateau, but not enough sampling has been done recently to determine if their presence is typical and at what concentrations they occur. To gain more information about the presence of agricultural pesticides in surface waters, four sites, representing different agricultural land uses in the study unit, were sampled for pesticides one to five times a month for a period of 15 months.

In studies of this type, the absence of readilyavailable information on pesticide use is an obstacle to understanding why some pesticides are found in hydrologic systems and others are not. For a pesticide to be present in water there must be a source of the pesticide; however, the presence of a source does not necessarily mean that the pesticide will be transported from the location of its application to a water body: a pesticide may volatilize, metabolize, or otherwise degrade before it reaches the water body. Pesticide-use data are essential to understanding how other factors, like degradation, affect the fate of a pesticide after it is applied. Therefore, obtaining data to determine pesticide use in the drainage basins of the sampled sites was another key element of this study.

\section{Purpose and Scope}

The purposes of this report are to (1) summarize concentrations of agricultural pesticides in surface water at four sites that were sampled one to five times a month from March 1993 through May 1994; (2) show graphically the relation between the concentrations of selected pesticides, streamflows, and the application periods of the pesticides; (3) present data on the quantities of pesticides used in the drainage basins of the sampled sites; and (4) document the methods used to collect and analyze the samples and the methods used to compile the pesticide-use data. Two of the four sampled sites were located in irrigated agricultural areas and two were located in dryland farming areas. Samples collected at the four sites were analyzed for about 85 pesticides, or target analytes, selected from a list of nearly 400 of the pesticides most commonly used in the United States. Pesticide concentration data and estimates of quantities of pesticides applied in the drainage basins of the four sites also are summarized in tables. Quality-control data including field-matrix and laboratory-reagent-spike results, field and equipment blanks, and replicate samples are summarized. Although some observations pertaining to the data are provided, this report contains no detailed analyses of the data.

\section{Description of the Study Unit}

The Central Columbia Plateau study unit is located in east-central Washington and northwestern Idaho (fig. 1). The approximately 13,000 square-mile area is bordered on the north by the Columbia River and the topographic divide in the headwaters of Crab Creek, on the east by the topographic divide in the headwaters of the Palouse River, on the south by the Snake River, and on the west by the Columbia River. The study unit has numerous land forms, including low-altitude mountains and rolling hills on the eastern side and a wide range of high-desert land forms throughout the western part of the study unit. The altitude of the land surface ranges from less than 300 feet above sea level near Pasco to nearly 5,000 feet above sea level in the mountains in the headwaters of the Palouse River. For a more complete description of the study unit, refer to Greene and others (1994). Four surface-water sites in the Central Columbia Plateau--two sites whose contributing drainage basins are representative of irrigated agricultural land use and two representative of dryland agriculture-were selected for investigation of use and occurrence of pesticides. 


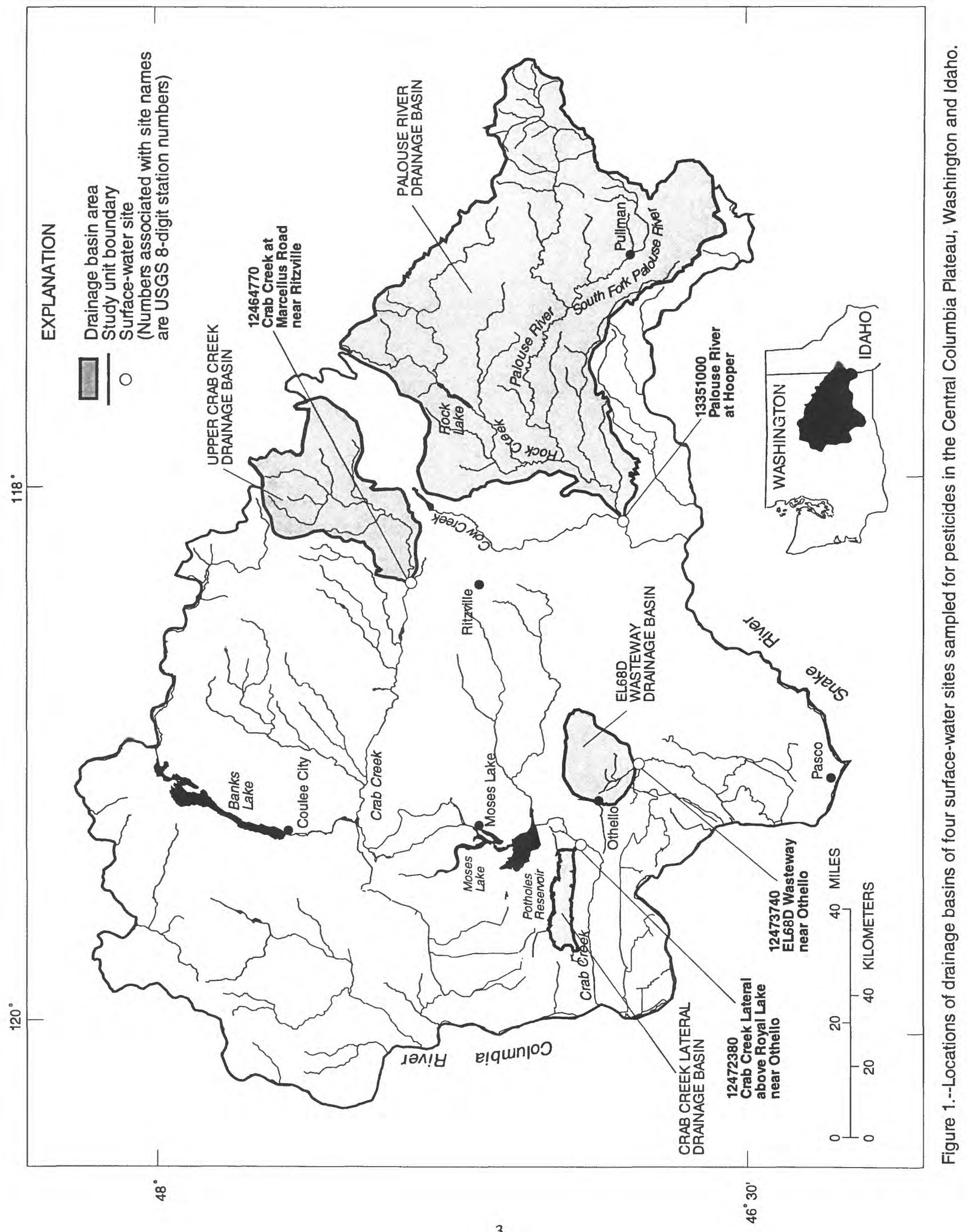


The dominant land use in the study unit is cropproduction agriculture, comprising a total area of about 8,000 square miles, or 62 percent of the area in the study unit. These lands can be further categorized as dryland farming and ground- and surface-water-irrigated farming (fig. 2). Other major land uses are rangeland (32 percent) and forest ( 5 percent).

To help identify the causes for observed waterquality conditions, the study unit was divided into three subunits that represent distinct geologic, hydrologic and land-use patterns (fig. 2). The Quincy-Pasco subunit lies in the arid southwestern part of the study unit. The subunit contains few natural perennial streams, and streamflows in the subunit are augmented and indirectly regulated by seasonal deliveries of large quantities of irrigation water to the area. The irrigation water is diverted from the Columbia River and delivered to farms in the subunit by a system of canals and laterals constructed by the Bureau of Reclamation. Because of the availabilit; of irrigation water and a suitable climate, many types of crops are grown in the subunit.

The North-Central subunit, located in the northern and central parts of the study unit, is the largest of the three subunits. Crab Creek originates in the northeastern part of the subunit, and within the subunit is a natural stream, which can be characterized as a classic high-desert stream with most of the base flow originating from springs along its course. Once Crab Creek enters the QuincyPasco subunit, streamflow in the creek is affected by the delivery of irrigation water to the area. The North-Central subunit contains both dryland and ground-water-irrigated farmland as well as extensive areas of rangeland.

The Palouse subunit in the eastern part of the study unit is characterized largely by the extent of the windblown, fine deposits (loess) that overlie the area. The loess develops into rich soils ideally suited for dryland farming, which is the major land use in the subunit. The subunit contains all of the Palouse River drainage basin except for the Cow Creek drainage basin and parts of the Rock Creek drainage basin, which are outside of the loess-covered area. There is little irrigation of farmland in the subunit.

Two of the sampling sites, Crab Creek Lateral and EL68D Wasteway, lie within the Quincy-Pasco subunit (fig. 2) and represent irrigated agricultural drainage basins. Although part of the drainage basin of EL68D Wasteway lies within the North-Central subunit and includes some dryland farming areas, the sampling site is considered to represent an irrigated agricultural area, because high streamflows occur during irrigation season when irrigation water is applied to crops (table 1). The other two sampling sites, Palouse River at Hooper and Crab Creek at Marcellus Road (hereafter referred to as Palouse River and Upper Crab Creek, respectively), represent dryland agricultural areas (fig. 2). The irrigated and dryland farming areas represent major differences in agricultural practices and crop types (table 2).

\section{Drainage Basins in the Irrigated Agricultural Areas}

Large quantities of imported surface water used for irrigation indirectly regulate most of the flow in both Crab Creek Lateral and EL68D Wasteway. High flows usually occur during the irrigation season (from mid-March to mid-October) when both the drainage basins convey excess irrigation water, return flows, and ground-water seepage from the areas irrigated by surface water. Low flows occur during winter when irrigation water is no longer delivered; however, storms sometimes produce runoff to EL68D Wasteway from the ground-water irrigated and dryland farming areas. Because average annual precipitation in the Quincy-Pasco subunit ranges from 6 to 8 inches, it contributes little to the natural streamflow in either drainage basin. Low streamflows in winter are caused by ground-water seepage.

Crab Creek Lateral drains 56 square miles and represents an area where farmland is irrigated almost entirely by surface water (fig. 2 and table 1). The 146-square-mile drainage basin of EL68D Wasteway includes both surfaceand ground-water-irrigated and dryland farming areas. Nearly half of the irrigated farmland in the Crab Creek Lateral drainage basin and three-quarters of the irrigated farmland in the EL68D Wasteway drainage basin are irrigated by gravity methods; the remainder is irrigated by sprinkler. Differences in the amounts of surface runoff produced from the two types of irrigation may affect pesticide transport to surface waters (Squillace and Thurman, 1992; Majewski and Capel, 1995). Alfalfa, wheat, beans, corn, and potatoes are the primary crop rotations in both drainage basins; however, the Crab Creek Lateral drainage basin also has a significant percentage of acreage dedicated to orchards, which are predominantly apple orchards (table 2). 


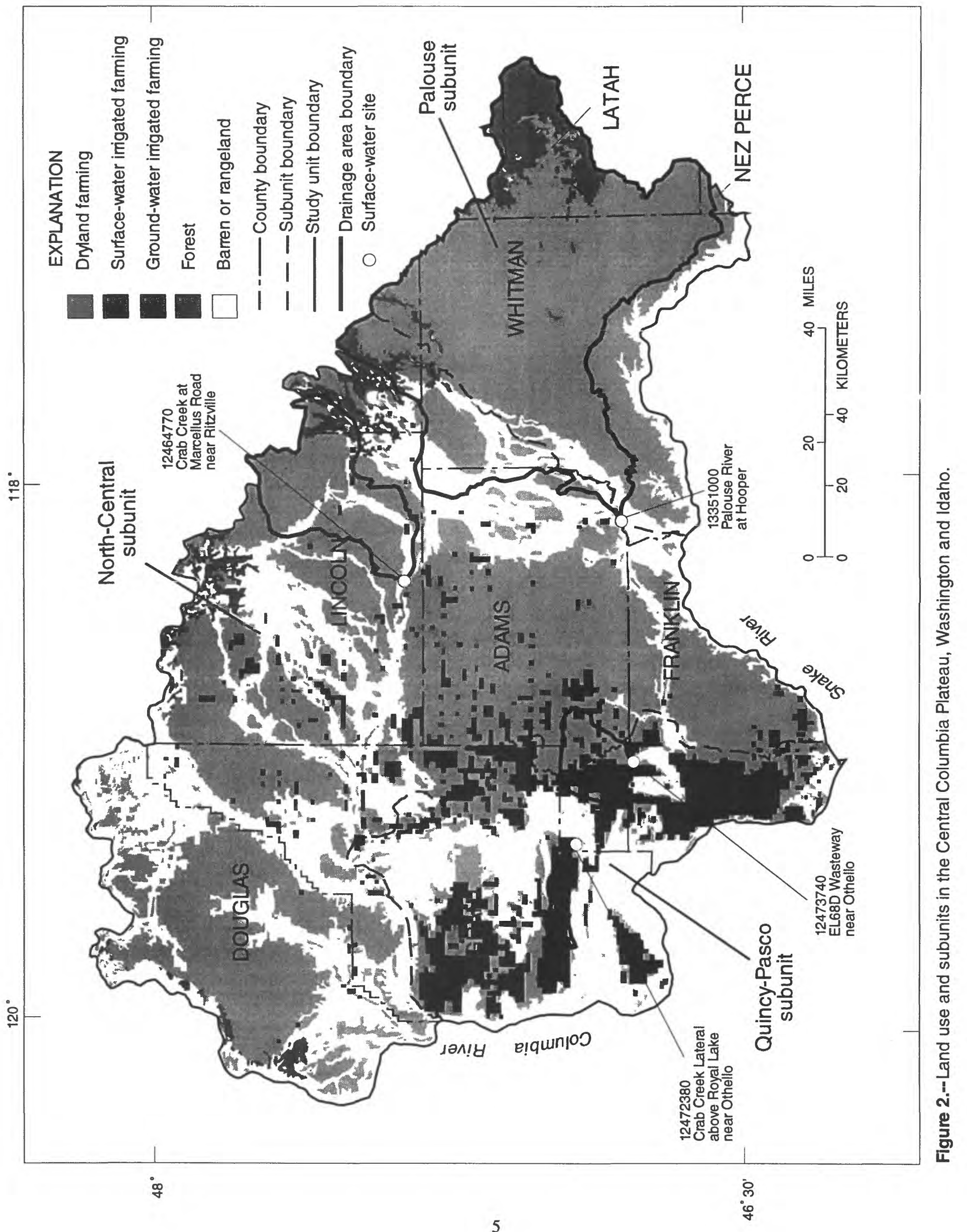


Table 1.--Physical and land-use characteristics of four drainage basins sampled for pesticides in the Central Columbia Plateau, Washington and Idaho

[Water year is from October 1 through September 30; USGS, U.S. Geological Survey; $\mathrm{ft}^{3} / \mathrm{s}$, cubic feet per second; $<$, less than; >, greater than. Harvested cropland areas were estimated using irrigation-block crop data in the irrigated drainage basins and Landsat and GIRAS data in the dryland drainage basins, unless indicated otherwise]

\begin{tabular}{|c|c|c|c|c|c|}
\hline $\begin{array}{l}\text { USGS } \\
\text { station number } \\
\text { and name }\end{array}$ & Short name & $\begin{array}{l}\text { Mean } \\
\text { streamflow } \\
\text { for } 1994 \\
\text { water year } \\
\left(\mathrm{ft}^{3} / \mathrm{s}\right)\end{array}$ & $\begin{array}{l}\text { Drainage } \\
\text { area } \\
\text { (square } \\
\text { miles) }\end{array}$ & $\begin{array}{l}\text { Harvested } \\
\text { cropland area } \\
\text { (square miles) }\end{array}$ & $\begin{array}{l}\text { Percentage } \\
\text { of cropland } \\
\text { irrigated }\end{array}$ \\
\hline
\end{tabular}

Irrigated Agricultural Drainage Basins

$\begin{array}{llllll}12472380 & \text { Crab Creek Lateral } & 41.2 & 56 & 38 & >95\end{array}$

Crab Creek Lateral above Royal Lake near

Othello, Wash.

12473740

EL68D Wasteway

133

146

152

${ }^{2} 55$

EL68D Wasteway

near Othello, Wash.

\section{Dryland Agricultural Drainage Basins}

12464770

Crab Creek at

Marcellus Road

near Ritzville, Wash.
13351000

Palouse River

at Hooper, Wash.
Upper Crab Creek

134

539

Palouse River

2,500

${ }^{3} 1,300$

$<1$

\footnotetext{
${ }^{1}$ Harvested cropland includes only areas irrigated by surface water, not dryland or areas irrigated by ground water (see fig. 2).

${ }^{2}$ Percent of all cropland in drainage basin irrigated by surface water and ground water.

${ }^{3}$ Crop acreages for Whitman County from 1992 (U.S. Department of Commerce, 1994) are used for Palouse River drainage basin.
} 
Table 2--Crop acreages in four drainage basins sampled for pesticides in the Central Columbia Plateau, Washington and Idaho

$[<$, less than; --, no data]

\begin{tabular}{|c|c|c|c|c|c|}
\hline Crop & Acres $^{1}$ & Percent & Acres ${ }^{1}$ & \multicolumn{2}{|c|}{ Percent } \\
\hline & \multicolumn{5}{|c|}{ Irrigated Agricultural Drainage Basins ${ }^{2}$} \\
\hline & \multicolumn{2}{|c|}{ Crab Creek Lateral } & \multicolumn{3}{|c|}{ EL68D Wasteway } \\
\hline Alfalfa hay & 5,500 & 22 & 6,600 & 19 & \\
\hline Irrigated wheat & 4,400 & 18 & 7,600 & 22 & \\
\hline Dry beans & 3,300 & 13 & 4,800 & 14 & \\
\hline Corn & 2,200 & 9 & 2,600 & 8 & \\
\hline Apples & 2,100 & 8 & 42 & $<1$ & \\
\hline Potatoes & 1,100 & 5 & 3,500 & 10 & \\
\hline Mint & 1,100 & 5 & 2,600 & 8 & \\
\hline Asparagus & 590 & 2 & 360 & 1 & \\
\hline Sweet corn & 530 & 2 & 110 & $<1$ & \\
\hline Pasture & 470 & 2 & 910 & 3 & \\
\hline Pea seed & 400 & 2 & 1,600 & 5 & \\
\hline Onions & 360 & 1 & 710 & 2 & \\
\hline Alfalfa seed & 330 & 1 & 130 & $<1$ & \\
\hline Other hay & 330 & 1 & 400 & 1 & \\
\hline Radish seed & 300 & 1 & 300 & $<1$ & \\
\hline Carrots & 290 & 1 & 12 & $<1$ & \\
\hline Irrigated barley & 230 & $<1$ & 390 & 1 & \\
\hline Bean seed & 130 & $<1$ & 500 & 1 & \\
\hline Other & 1,500 & 5 & 900 & 3 & \\
\hline \multirow[t]{3}{*}{ Total } & $\overline{25,160}$ & $\overline{98}$ & $\overline{34,064}$ & $\overline{98}$ & \\
\hline & \multicolumn{4}{|c|}{ Dryland Agricultural Drainage Basins } & \\
\hline & \multicolumn{2}{|c|}{ Upper Crab Creek 3} & \multicolumn{3}{|c|}{ Palouse River } \\
\hline Wheat & 98,000 & 37 & 473,000 & 34 & \\
\hline Fallow & 70,000 & 27 & 317,000 & 23 & \\
\hline Barley & 23,000 & 9 & 168,000 & 12 & \\
\hline Pasture and range & 69,000 & 27 & 268,000 & 19 & \\
\hline Dry peas & & $<1$ & 91,000 & 7 & \\
\hline Lentils & & $<1$ & 55,000 & 4 & \\
\hline Other & 270 & $<1$ & 24,000 & 1 & \\
\hline Total & $\overline{260,270}$ & $\overline{100}$ & $\overline{1,396,000}$ & $\overline{100}$ & \\
\hline
\end{tabular}

${ }^{1}$ Crop acreages are approximate because multiple sources of data were used to estimate acreages, and the different sources of data represent different time periods.

${ }^{2}$ Crop acreages are for areas irrigated by surface water only and are an average of irrigation-block crop data for the period 1987-91 (Alan Hattrup, Bureau of Reclamation, written commun., 1991).

${ }^{3}$ Acreages of crops irrigated by ground water and some adjoining non-irrigated cropland are from 1985 Landsat imagery (Van Metre and Seevers, 1991). Outside of the areas covered by Landsat imagery, the total acres of cropland and pasture were obtained from 1972 GIRAS digital land-use land-cover data (U.S. Geological Survey, 1986). Crop statistics for Lincoln County from 1992 (U.S. Department of Commerce, 1994) were applied to the areas covered by GIRAS data to estimate acreages of individual crops.

${ }^{4}$ Crop acreages for Whitman County from 1992 (U.S. Department of Commerce, 1994) are used for Palouse River drainage basin. 


\section{Drainage Basins in the Dryland Agricultural Areas}

Average annual precipitation ranges from about 13 to 16 inches in the Upper Crab Creek drainage basin, and from about 13 to 25 inches in the Palouse River drainage basin (Greene and others, 1994). High streamflows usually occur during winter storms and following periods of snow melt, especially in the upper parts of the Palouse River drainage basin. Low streamflows in Upper Crab Creek and the Palouse River occur during summer. Storm runoff in both drainage basins during winter and spring causes soil erosion and subsequent transport of sediment from cropland to streams, as documented in the Palouse River drainage basin (Boucher, 1970). The quantity of precipitation is sufficient to support dryland farming in most of both drainage basins. Upper Crab Creek drains 384 square miles and the agricultural land use in this drainage basin is predominantly dryland farming. The Palouse River drains nearly 2,500 square miles and dryland farming is the predominant land use. Major crops in the Upper Crab Creek drainage basin are wheat and barley; and more than half of the acreage in the drainage basin is used for pasture, range, or fallow cropland. Wheat is the major crop grown in the Palouse River drainage basin. The other major crops include barley, dry peas, and lentils; and nearly half of the acreage in the drainage basin is used for pasture, range, or fallow cropland (table 2). In addition to a greater diversity of crops, the Palouse River drainage basin contains many small communities distributed throughout the basin and a forested area in the headwaters. The Palouse River drainage basin is unique in that it receives discharges from waste-water treatment plants. During summer, discharges from waste-water treatment plants make up most of the streamflow in the South Fork Palouse River.

\section{METHODS}

The primary objectives of this report were to summarize pesticide concentrations at four surface-water sites and to observe any correspondence between pesticide concentrations, pesticide use, and streamflows. A major sampling effort was required for the sampling and analysis of pesticides in surface waters during all flow regimes. Because the method used to extract pesticides from field samples has been implemented only recently, and because the techniques used to analyze the samples produce a broad spectrum of pesticide analytes at low limits of detections, these methods are documented or referenced in the following section. Data related to pesticide use were gathered from multiple sources, and several methods were used to process the data digitally. Because the methods used to process and compile the pesticide-use data were complicated, they are documented in this report. This section outlines the surface-water sampling procedures, including sample collection, lab analysis, and results of quality-control samples, and then discusses how pesticide-use data were processed.

\section{Sampling Pesticides in Surface Waters}

Pesticides analyzed in surface-water samples were selected from a list of nearly 400 of the pesticides most commonly used in the United States (Gianessi and Puffer, 1991, 1992a, 1992b). The pesticides were prioritized according to the following factors: a national use of more than 8,000 pounds of active ingredient; inclusion in the analytical schedules of other Federal monitoring or survey programs; toxicity; leachability; and the ability to trap and extract the analyte from the appropriate solid-phaseconcentrating matrix (Gilliom and others, 1995). The final target-analyte list (table 3 ) is a broad spectrum of pesticides analyzed using gas chromatography/mass spectrometry (GC/MS) or high-performance liquid chromatography (HPLC) techniques (Sandstrom and others, 1992). Samples were collected, field-extracted, and submitted to the U.S. Geological Survey National Water Quality Laboratory (NWQL) in Arvada, Colo., for analysis.

\section{Field Procedures}

Samples representative of the flow in the stream cross section were obtained by collecting depth-integrated subsamples at equally spaced verticals across the stream using either the US DH-81 or US D-77 sampler as described by Edwards and Glysson (1988) and Shelton (1994). Both samplers hold a 3-liter Teflon sample bottle, and all parts of the sampler coming into contact with sample water are constructed of Teflon. Samples were composited in a glass carboy in order to integrate the stream cross section at sites where more than one 3-liter bottle was needed to sample all verticals. All equipment used to collect and process samples was cleaned with a 0.2-percent non-phosphate detergent, rinsed with deionized water, rinsed with pesticide-grade methanol, air-dried, wrapped in aluminum foil, and stored in a dust-free environment prior to sample collection (Shelton, 1994). 
Table 3.--Pesticide target analytes, method detection limits, drinking water standards, and aquatic-life criteria

$[\mu \mathrm{g} / \mathrm{L}$, micrograms per liter; $\mathrm{H}$, herbicide; I, insecticide; $\mathrm{M}$, metabolite; $\mathrm{F}$, fungicide; --, no data; drinking water standards are U.S. Environmental Protection Agency primary drinking water standards from Nowell and Resek (1994), unless otherwise footnoted; freshwater-chronic criteria for protection of aquatic life are U.S. Environmental Protection Agency standards from Nowell and Resek (1994), unless otherwise footnoted]

\begin{tabular}{|c|c|c|c|c|c|c|}
\hline $\begin{array}{l}\text { Pesticide } \\
\text { target analytes }\end{array}$ & $\begin{array}{l}\text { Trade } \\
\text { or } \\
\text { common } \\
\text { name }\end{array}$ & $\begin{array}{l}\text { Type } \\
\text { of } \\
\text { pesti- } \\
\text { cide }\end{array}$ & $\begin{array}{l}\text { Chemical } \\
\text { Abstract } \\
\text { Services } \\
\text { registry } \\
\text { number }\end{array}$ & $\begin{array}{l}\text { Method } \\
\text { detection } \\
\text { limit } \\
(\mu \mathrm{g} / \mathrm{L})\end{array}$ & $\begin{array}{l}\text { Drinking } \\
\text { water } \\
\text { standards or } \\
\text { guidelines } \\
(\mu \mathrm{g} / \mathrm{L})\end{array}$ & $\begin{array}{l}\text { Freshwater- } \\
\text { chronic criteria } \\
\text { for protection } \\
\text { of aquatic life } \\
(\mu \mathrm{g} / \mathrm{L})\end{array}$ \\
\hline
\end{tabular}

Gas Chromatography/Mass Spectrometry analytical data

\begin{tabular}{|c|c|c|c|c|c|c|}
\hline Alachlor & Lasso & $\mathrm{H}$ & $15972-60-8$ & 0.002 & 2 & -- \\
\hline Atrazine $^{1}$ & AAtrex & $\mathrm{H}$ & $1912-24-9$ & ${ }^{1} 0.009$ & 3 & ${ }^{2} 2$ \\
\hline Azinphos-methyl ${ }^{3}$ & Guthion & I & $86-50-0$ & 0.001 & - & 0.01 \\
\hline Benfluralin & Balan, Benefin & $\mathrm{H}$ & $1861-40-1$ & 0.002 & -- & -- \\
\hline Butylate & Sutan + , Genate Plus & $\mathrm{H}$ & $2008-41-5$ & 0.002 & ${ }^{4} 700$ & -- \\
\hline Carbaryl $1^{3,5}$ & Sevin, Savit & I & $63-25-2$ & 0.003 & ${ }^{4} 700$ & ${ }^{6} 0.02$ \\
\hline Carbofuran 3,5 & Furadan & I & $1563-66-2$ & 0.003 & 40 & ${ }^{2} 1.75$ \\
\hline Chlorpyrifos & Genpest, Lorsban & I & $2921-88-2$ & 0.004 & ${ }^{4} 20$ & 0.041 \\
\hline Cyanazine & Bladex & $\mathrm{H}$ & $21725-46-2$ & 0.004 & ${ }^{4} 1$ & ${ }^{7} 2$ \\
\hline DCPA & Dacthal & $\mathrm{H}$ & $1861-32-1$ & 0.002 & ${ }^{4} 4,000$ & -- \\
\hline$p, p^{\prime}-\mathrm{DDE}$ & none & $\mathbf{M}$ & $72-55-9$ & 0.006 & -- & -- \\
\hline Desethyl atrazine ${ }^{3}$ & none & $\mathbf{M}$ & $6190-65-4$ & 0.002 & -- & -- \\
\hline Diazinon & several & I & $333-41-5$ & 0.002 & ${ }^{4} 0.6$ & ${ }^{6} 0.009$ \\
\hline Dieldrin & Panoram D-31 & I & $60-57-1$ & 0.001 & -- & 0.0651 \\
\hline 2,6-Diethylanaline & none & M & $579-66-8$ & 0.003 & -- & -- \\
\hline Dimethoate $^{3,8}$ & Cygon & I & $60-51-5$ & 0.004 & -- & -- \\
\hline Disulfoton & Di-Syston & I & 298-04-4 & 0.017 & ${ }^{4} 0.3$ & ${ }^{6} 0.05$ \\
\hline EPTC & Eptam, Eradicane & $\mathrm{H}$ & $759-94-4$ & 0.002 & -- & -- \\
\hline Ethalfluralin & Sonalan, Curbit EC & $\mathrm{H}$ & $55283-68-6$ & 0.004 & -- & -- \\
\hline Ethoprop & Mocap & I & $13194-48-4$ & 0.003 & -- & -- \\
\hline Fonofos & Dyfonate & $I$ & $944-22-9$ & 0.003 & ${ }^{4} 10$ & -- \\
\hline alpha-HCH & none & M & $319-84-6$ & 0.002 & -- & -- \\
\hline gamma-HCH & Lindane & I & $58-89-9$ & 0.004 & 0.2 & 0.08 \\
\hline Linuron $^{5}$ & Lorox, Linex & $\mathrm{H}$ & $330-55-2$ & 0.002 & -- & -- \\
\hline Malathion & several & I & $121-75-5$ & 0.005 & ${ }^{4} 200$ & 0.1 \\
\hline Methyl parathion & Penncap-M & I & $298-00-0$ & 0.006 & ${ }^{4} 2$ & -- \\
\hline Metolachlor & Dual, Pennant & $\mathrm{H}$ & $51218-45-2$ & 0.002 & ${ }^{4} 100$ & ${ }^{7} 8$ \\
\hline Metribuzin & Lexone, Sencor & $\mathrm{H}$ & $21087-64-9$ & 0.004 & ${ }^{4} 200$ & ${ }^{7} 1$ \\
\hline Molinate & Ordram & $\mathrm{H}$ & $2212-67-1$ & 0.004 & -- & -- \\
\hline Napropamide & Devrinol & $\mathrm{H}$ & $15299-99-7$ & 0.003 & -- & -- \\
\hline Parathion & several & I & $56-38-2$ & 0.004 & -- & 0.013 \\
\hline Pebulate & Tillam & $\mathrm{H}$ & $1114-71-2$ & 0.004 & -- & -- \\
\hline Pendimethalin & Prowl,Stomp & $\mathrm{H}$ & $40487-42-1$ & 0.004 & -- & -- \\
\hline cis-Permethrin & Ambush, Pounce & I & $57608-04-5$ & 0.005 & -- & -- \\
\hline Phorate & Thimet, Rampart & I & $298-02-2$ & 0.002 & -- & -- \\
\hline Prometon & Pramitol & $\mathrm{H}$ & $1610-18-0$ & 0.018 & ${ }^{4} 100$ & -- \\
\hline
\end{tabular}


Table 3.--Pesticide target analytes, method detection limits, drinking water standards, and aquatic-life criteria--Continued

\begin{tabular}{|c|c|c|c|c|c|c|}
\hline $\begin{array}{l}\text { Pesticide } \\
\text { target analytes }\end{array}$ & $\begin{array}{l}\text { Trade } \\
\text { or } \\
\text { common } \\
\text { name }\end{array}$ & $\begin{array}{l}\text { Type } \\
\text { of } \\
\text { pesti- } \\
\text { cide }\end{array}$ & $\begin{array}{l}\text { Chemical } \\
\text { Abstract } \\
\text { Services } \\
\text { registry } \\
\text { number }\end{array}$ & $\begin{array}{l}\text { Method } \\
\text { detection } \\
\text { limit } \\
(\mu \mathrm{g} / \mathrm{L})\end{array}$ & $\begin{array}{l}\text { Drinking } \\
\text { water } \\
\text { standards or } \\
\text { guidelines } \\
(\mu \mathrm{g} / \mathrm{L})\end{array}$ & $\begin{array}{l}\text { Freshwater- } \\
\text { chronic criteria } \\
\text { for protection } \\
\text { of aquatic life } \\
(\mu \mathrm{g} / \mathrm{L})\end{array}$ \\
\hline
\end{tabular}

Gas Chromatography/Mass Spectrometry analytical data--Continued

\begin{tabular}{|c|c|c|c|c|c|c|}
\hline Pronamide & Kerb & $\mathrm{H}$ & $23950-58-5$ & 0.003 & ${ }^{4} 50$ & -- \\
\hline Propachlor & Ramrod & $\mathrm{H}$ & $1918-16-7$ & 0.007 & 490 & -- \\
\hline Propanil & Stampede & $\mathrm{H}$ & $709-98-8$ & 0.004 & -- & -- \\
\hline Propargite & Comite, Omite & I & $2312-35-8$ & 0.013 & -- & -- \\
\hline Simazine & Aquazine, Princep & $\mathrm{H}$ & $122-34-9$ & 0.005 & 4 & ${ }^{6} 10$ \\
\hline Tebuthiuron & Spike & $\mathrm{H}$ & $34014-18-1$ & 0.01 & ${ }^{4} 500$ & -- \\
\hline Terbacil $^{3}$ & Sinbar & $\mathrm{H}$ & $5902-51-2$ & 0.007 & ${ }^{4} 90$ & -- \\
\hline Terbufos & Counter & I & $13071-79-9$ & 0.013 & ${ }^{4} 0.9$ & -- \\
\hline Thiobencarb & Bolero & $\mathrm{H}$ & $28249-77-6$ & 0.002 & -- & -- \\
\hline Triallate & Far-Go & $\mathrm{H}$ & $2303-17-5$ & 0.001 & -- & ${ }^{7} 0.24$ \\
\hline Trifluralin & Treflan, Trilin & $\mathrm{H}$ & $1582-09-8$ & 0.002 & ${ }^{4} 5$ & ${ }^{2} 0.1$ \\
\hline
\end{tabular}

High-Performance Liquid Chromatography analytical data

\begin{tabular}{|c|c|c|c|c|c|c|}
\hline 1-Naphthol ${ }^{9,10}$ & none & $\mathbf{M}$ & $90-15-3$ & 0.007 & -- & -- \\
\hline $2,4-\mathrm{D}$ & several & $\mathrm{H}$ & $94-75-7$ & 0.035 & 70 & ${ }^{6} 3$ \\
\hline 2,4-DB & none & I & $94-82-6$ & 0.035 & -- & -- \\
\hline $2,4,5-\mathrm{T}$ & several & $\mathrm{H}$ & $93-76-5$ & 0.035 & ${ }^{4} 70$ & -- \\
\hline $2,4-5-\mathrm{TP}^{10}$ & Silvex & $\mathrm{H}$ & $93-72-1$ & 0.021 & 50 & ${ }^{6} 1.4$ \\
\hline $\begin{array}{l}\text { 3-Hydroxy- } \\
\text { carbofuran }{ }^{10}\end{array}$ & none & $\mathbf{M}$ & $1563-38-8$ & 0.014 & -- & -- \\
\hline Acifluorfen & Blazer & $\mathrm{H}$ & $50594-66-6$ & 0.035 & -- & -- \\
\hline Aldicarb $^{10}$ & Temik & I & $116-06-3$ & 0.016 & 3 & -- \\
\hline Aldicarb sulfone ${ }^{10}$ & Standak & $\mathbf{M}$ & $1646-88-4$ & 0.016 & 2 & -- \\
\hline Aldicarb sulfoxide & none & M & $1646-87-3$ & 0.021 & 4 & -- \\
\hline Bentazon & Basagran & $\mathrm{H}$ & $25057-89-0$ & 0.014 & ${ }^{4} 20$ & -- \\
\hline Bromacil & Hyvar, Urox B & $\mathrm{H}$ & $314-40-9$ & 0.035 & ${ }^{4} 90$ & -- \\
\hline Bromoxynil & Buctril, Brominal & $\mathrm{H}$ & $1689-84-5$ & 0.035 & -- & 25 \\
\hline Carbary $1^{5,10}$ & Sevin, Savit & I & $63-25-2$ & 0.008 & ${ }^{4} 700$ & ${ }^{6} 0.02$ \\
\hline Carbofuran ${ }^{5,10}$ & Furadan & I & $1563-66-2$ & 0.028 & 40 & ${ }^{2} 1.75$ \\
\hline Chloramben & Amiben, Vegiben & $\mathrm{H}$ & $133-90-4$ & 0.011 & ${ }^{4} 100$ & -- \\
\hline Chlorothalonil $^{9}$ & Bravo & $\mathrm{F}$ & $1897-45-6$ & 0.035 & -- & -- \\
\hline Clopyralid & Stinger, Lontrel & $\mathrm{H}$ & $1702-17-6$ & 0.05 & -- & -- \\
\hline $\begin{array}{l}\text { Dacthal, } \\
\text { mono-acid) }\end{array}$ & none & $\mathbf{M}$ & $887-54-7$ & 0.017 & -- & -- \\
\hline Dicamba & Banvel & $\mathrm{H}$ & $1918-00-9$ & 0.035 & ${ }^{4} 200$ & ${ }^{7} 10$ \\
\hline Dichlobenil $^{9}$ & Barrier, Casoron & $\mathrm{H}$ & $1194-65-6$ & 0.02 & -- & 637 \\
\hline Dichlorprop & 2,4-DP, Seritox 50 & $\mathrm{H}$ & $120-36-5$ & 0.032 & -- & -- \\
\hline Dinoseb & DNBP, Dinitro & $\mathrm{H}$ & $88-85-7$ & 0.035 & 7 & ${ }^{2} 0.05$ \\
\hline Diuron & Karmex, Direx & $\mathrm{H}$ & $330-54-1$ & 0.02 & ${ }^{4} 10$ & ${ }^{6} 1.6$ \\
\hline
\end{tabular}


Table 3.--Pesticide target analytes, method detection limits, drinking water standards, and aquatic-life criteria--Continued

\begin{tabular}{|c|c|c|c|c|c|c|}
\hline $\begin{array}{l}\text { Pesticide } \\
\text { target analytes }\end{array}$ & $\begin{array}{l}\text { Trade } \\
\text { or } \\
\text { common } \\
\text { name }\end{array}$ & $\begin{array}{l}\text { Type } \\
\text { of } \\
\text { pesti- } \\
\text { cide }\end{array}$ & $\begin{array}{l}\text { Chemical } \\
\text { Abstract } \\
\text { Services } \\
\text { registry } \\
\text { number }\end{array}$ & $\begin{array}{l}\text { Method } \\
\text { detection } \\
\text { limit } \\
(\mu \mathrm{g} / \mathrm{L})\end{array}$ & $\begin{array}{l}\text { Drinking } \\
\text { water } \\
\text { standards or } \\
\text { guidelines } \\
(\mu \mathrm{g} / \mathrm{L})\end{array}$ & $\begin{array}{l}\text { Freshwater- } \\
\text { chronic criteria } \\
\text { for protection } \\
\text { of aquatic life } \\
(\mu \mathrm{g} / \mathrm{L})\end{array}$ \\
\hline
\end{tabular}

High-Performance Liquid Chromatography analytical data--Continued

\begin{tabular}{|c|c|c|c|c|c|c|}
\hline DNOC $^{9}$ & Trifocide, Elgetol 30 & $\mathrm{I}, \mathrm{F}, \mathrm{H}$ & $534-52-1$ & 0.035 & -- & -- \\
\hline Esfenvalerate $^{9}$ & Asana XL & I & $66230-04-4$ & 0.019 & -- & -- \\
\hline Fenuron & Beet-Kleen & $\mathrm{H}$ & $101-42-8$ & 0.013 & -- & -- \\
\hline Fluometuron & Flo-Met, Cotoran & $\mathrm{H}$ & $2164-17-2$ & 0.035 & ${ }^{4} 90$ & -- \\
\hline Linuron ${ }^{5}$ & Lorox, Linex & $\mathrm{H}$ & $330-55-2$ & 0.018 & -- & -- \\
\hline MCPA & Metaxon, Kilsem & $\mathrm{H}$ & $94-74-6$ & 0.05 & ${ }^{4} 10$ & -- \\
\hline MCPB & Can-Trol, Thistrol & $\mathrm{H}$ & $94-81-5$ & 0.035 & -- & - \\
\hline Methiocarb $^{10}$ & Grandslam, Mesurol & I & $2032-65-7$ & 0.026 & -- & -- \\
\hline Methomyl & Lannate, Nudrin & I & $16752-77-5$ & 0.017 & ${ }^{4} 200$ & -- \\
\hline Neburon & Neburex, Noruben & $\mathrm{H}$ & $555-37-3$ & 0.015 & -- & -- \\
\hline Norflurazon & Evital, Solicam & $\mathrm{H}$ & $27314-13-2$ & 0.024 & -- & -- \\
\hline Oryzalin & Surflan & $\mathrm{H}$ & $19044-88-3$ & 0.019 & -- & -. \\
\hline Oxamyl ${ }^{10}$ & Vydate & I & $23135-22-0$ & 0.018 & 200 & -- \\
\hline Picloram $^{10}$ & Tordon & $\mathrm{H}$ & $1918-02-1$ & 0.05 & 500 & - \\
\hline Propham & Chem-Hoe, IPC & $\mathrm{H}$ & $122-42-9$ & 0.035 & ${ }^{4} 100$ & -- \\
\hline Propoxur & Baygon & I & $114-26-1$ & 0.035 & -- & -- \\
\hline Triclopyr $^{10}$ & Garlon, Grazon & $\mathrm{H}$ & $55335-06-3$ & 0.05 & -- & - \\
\hline
\end{tabular}

\footnotetext{
${ }^{1}$ Estimated reporting limit due to bias in concentrations of atrazine in field and equipment blanks (see section titled Results of Quality-Control Samples).

${ }^{2}$ Guidelines for the protection of freshwater aquatic life are Canadian Water Quality Guidelines from Canadian Council of Ministers of the Environment (1993).

${ }^{3}$ Concentrations for these pesticides are qualitatively identified and reported with an $E$ code (estimated value) because of problems with gas chromatography or extraction (Zaugg and others, 1995).

${ }^{4}$ U.S. Environmental Protection Agency lifetime-health advisories for a 70 kilogram adult, from Nowell and Resek (1994).

${ }^{5}$ Analyzed by both gas chromatography/mass spectrometry and high-performance liquid chromatography methods.

${ }^{6}$ Criteria for the protection of freshwater aquatic life are recommended maximum concentrations in water by National Academy of Sciences and National Academy of Engineers from Nowell and Resek (1994).

${ }^{7}$ Interim guidelines for the protection of freshwater aquatic life are Canadian Water Quality Guidelines from Canadian Council of Ministers of the Environment (1993).

${ }^{8}$ Pesticide demonstrated small and variable recovery and was removed from the method schedule in November 1994.

${ }^{9}$ The concentration values for these analytes are qualitatively identified and reported with an $\mathrm{E}$ code because of poor overall recovery and precision (NAWQA/NWQL Quality Assurance Committee for the Schedule 2050/2051

Pesticide Analysis Method, written commun., 1995).

${ }^{10}$ Pesticide target analyte is heat and light sensitive and therefore susceptible to degradation. This may result in poor overall recovery and precision (NAWQA/NWQL Quality Assurance Cornmittee for the Schedule 2050/2051

Pesticide Analysis Method, written commun., 1995).
} 
Samples of one 1-liter volume were filtered through a $0.7 \mu \mathrm{m}$ (micrometer) glass-fiber filter, and pesticides were field-extracted from the filtrate by sequentially pumping through solid-phase extraction (SPE) cartridges. Two cartridges were processed separately, each containing an extraction matrix applicable to a different set of analytes. The SPE cartridges were stored in amber, pesticide-free vials at less than 4 degrees Celsius for shipment to the NWQL. Detailed descriptions of equipment required and the procedures used to collect, process, and extract the sample using the SPE method are given in Shelton (1994). The SPE processing and extraction procedure is also discussed by Sandstrom and others (1992).

\section{Laboratory Procedures}

The SPE cartridges were eluted at the NWQL and the samples were analyzed using either SC/MS or HPLC techniques, depending on the physical characteristics of the target analytes (table 3 ). Those compounds that were sufficiently volatile and thermally stable for gas chromatography were analyzed with the GC/MS method, and the others were analyzed using the HPLC method. These techniques are described in detail by Zaugg and others (1995) and in unpublished NWQL documents (Mark Burkhardt, U.S. Geological Survey, written commun., 1994). Using these methods, concentrations of analytes can be reported that are below the method detection limit (Jeffrey Pritt, U.S. Geological Survey, written commun., 1994). In these cases, the compound has been positively identified, but the numerical value of the concentration has larger variability than those values that are above the method detection limit. In some cases where interference caused by the sample matrix may mask an analyte at concentrations greater than the method detection level, the laboratory reports either a raised reporting limit based on analyst's judgement or a deletion code indicating that it is unable to determine the analyte because of interference. Several GC/MS analytes (dimethoate, desethyl atrazine, carbofuran, carbaryl, terbacil, and azinphos-methyl) have low precision and recoveries or variable performance because of problems in the GC/MS procedure (Zaugg and others, 1995). These analytes are also reported, but the numerical value of the concentration has larger bias and variability than the other target analytes. There are also several HPLC analytes (aldicarb, aldicarb sulfone, carbaryl, carbofuran, chlorothalonil, dichlobenil, DNOC, esfenvalerate, oxamyl, 1-naphthol, MCPB, and methiocarb) that should be treated qualitatively because of poor overall recovery and precision or possible degradation at elevated temperatures (NAWQA/NWQL Quality Assurance Committee for the Schedule 2050/2051 Pesticide Analysis Method, written commun., 1995).

\section{Results of Quality-Control Samples}

About 15 percent of all samples submitted to the laboratory were quality-control samples, which included field blanks and equipment blanks to measure contamination and bias, replicate samples to measure variability, and field-matrix spike samples to measure recovery of analytes. For a definition of these quality-control samples, see Shelton (1994). Additionally, quality-control samples were routinely analyzed as part of the laboratory qualityassurance plan described by Pritt and Raese (1992). Fieldand equipment-blank samples were free of the compounds of interest, except for atrazine, which was detected at concentrations ranging from 0.003 to $0.008 \mu \mathrm{g} / \mathrm{L}$ (microgram per liter) in five of eight field blanks from the four sampling sites. Equipment blanks, which are composed of pesticide-free water passed through the field-extraction and laboratory equipment, but not through the sampling equipment, also contained similarly low concentrations of atrazine, indicating that the atrazine detections in blanks were probably caused by residual contamination in the processing equipment. All environmental samples of atrazine are affected by this bias: all detections could have a positive bias of 0 to $0.008 \mu \mathrm{g} / \mathrm{L}$; therefore, all environmental values are being reported at no lower than $0.009 \mu \mathrm{g} / \mathrm{L}$, with one significant figure, and are footnoted to indicate this bias. The bias had minimal impact on the concentrations of atrazine that are reported for water samples from the irrigated area because detections were generally above $0.008 \mu \mathrm{g} / \mathrm{L}$; however, the bias negated several of the detections in the two dryland areas. Additional information about the results of quality-control samples are available in files of the U.S. Geological Survey in the Washington District office.

Precision data were obtained from 27 sets of replicate samples (see appendix A1 at the end of the report). Except for 2,4-D, concentration differences within replicate sets ranged from 0.0 percent to 35.3 percent as measured by the relative standard deviation or relative percent difference. The relative percent difference for 2,4-D was more than 100 percent. This large percent difference could be attributed to possible co-elution of the acidfraction analyte into the base/neutral fraction, which 
would have resulted in lower recoveries since the acid analytes are not analyzed for in the base/neutral fraction (NAWQA/NWQL Quality Assurance Committee for the Schedule 2050/2051 Pesticide Analysis Method, written commun., 1995).

Precision and recoveries of HPLC target analytes were generally lower than the precision and recoveries of GC/MS target analytes, and the analyte recoveries and precision of field-matrix spike samples were generally lower than laboratory-reagent spike samples (see appendix $\mathrm{A} 2$ at the end of the report). Precision and recoveries for most of the 41 HPLC analytes generally are high enough and consistent enough that the data are acceptable for publication and will be useful for data analysis (NAWQA/ NWQL Quality Assurance Committee for the Schedule 2050/2051 Pesticide Analysis Method, written commun., 1995). However, because of the lower recoveries, the probability of false negatives is greater for the HPLC target analytes and the effective detection le el is proportionally larger. Precision and recoveries for these analytes need to be considered when interpreting the data.

\section{Pesticide Use Data}

In this report, pesticide use refers to both the quantity of pesticides applied to cropland and the timing of pesticide applications. Estimates of the total quantity of each pesticide applied annually in each drainage basin were computed as the sum of annual applications of that pesticide to each crop type in the drainage basin; these estimates were calculated as described below. Data on the timing of pesticide applications were provided by Anderson and Gianessi (1995), Mark Neilson (Franklin Conservation District, written commun., 1995), Gary Pelter (Washington State University Cooperative Extension Agency, written commun., 1995), Robert Gillespie (Washington State University Cooperative Extension Agency, written commun., 1995), and Elvin Kulp (Washington State University Cooperative Extension Agency, written commun., 1995).

For each herbicide, insecticide, and fungicide applied to a specific crop in a given drainage basin, the total quantity used annually was computed as the product of the rate of pesticide application to that crop (in pounds of active ingredient per acre per year), the total acreage of the crop in the drainage basin, and the percentage of that total acreage estimated to be treated with the pesticide. Pesticide application rates and treatment percentages were obtained from a 1995 survey conducted in the study unit by the National Center for Food and Agricultural Policy
(Anderson and Gianessi, 1995). Data on total acreages of crops in the four drainage basins were compiled from a much broader array of sources; the following is a brief description of these data sources and an explanation of the manner in which crop-acreage data were synthesized from them.

Two sources offered crop-acreage data for irrigated areas. For crops irrigated by ground water, Van Metre and Seevers (1991) used 1985 Landsat imagery to identify and map crops for the purpose of estimating ground-water pumpage on the Columbia Plateau. For crops irrigated by surface water, reports from the Bureau of Reclamation in 1987-1991(Alan Hattrup, written commun., 1991) provided data to compute average crop acreages within irrigation blocks for the 5-year period. An irrigation block is a group of farm units that receive initial delivery of irrigation water in the same year. Irrigation blocks range in size from about 600 to 27,000 acres.

The best available acreage data for dryland farming areas were U.S. Geological Survey digital land-use and land-cover data sets stored in the Geographic Information Retrieval and Analysis System (GIRAS) (U.S. Geological Survey, 1986). Because the GIRAS land-use data present cropland and pasture in a combined distribution as of 1972, statistics obtained from other sources were needed to estimate acreages of individual crops in the present dryland farming areas (see table 2). Crop acreages reported in table 2 are approximate because multiple sources of data were used to estimate acreages, and the different sources of data represent different time periods (1985 for areas irrigated by ground water; 1992 for areas of dryland farming; and an average of the years 1987 through 1991 for areas irrigated by surface water). Except for the areas irrigated by surface water, where crop acreages represent an average over a 5-year period, the crop acreages are based on data for a single year. Therefore, year-to-year changes in crop distributions, which likely affect pesticide use, are not reflected in the data.

Crop acreages derived from Landsat, irrigationblock, and GIRAS data were apportioned to the four drainage basins using a geographic information system (GIS). Crops from each data set were mapped to individual drainage basins by digital overlay of GIS boundaries of crop acreages, irrigation blocks, and drainage basins. Within each drainage basin, the total number of acres of a specific crop was computed as the sum of all the ground-water irrigated, surface-water irrigated, and GIRAS (dryland) acres of the crop. The Landsat interpretation of ground-water irrigated crop acreages contains the most specific crop location and distribution data and was therefore given 
priority in cases where it overlapped either irrigationblock boundaries or GIRAS dryland farming areas. Acreages of crops irrigated by surface water were allotted to drainage basins according to the fraction of the area of the irrigation block falling within the drainage basin. For example, where 70 percent of the area of a block lay within a drainage basin, 70 percent of the block's crop acreages were assigned to the drainage basin. Where ground- and surface-water irrigated crop data were unavailable, GIRAS data were used to map dryland crop areas, and data from other sources were used to estimate acreages of individual crops within these areas

(see table 2).

\section{CONCENTRATIONS OF PESTICIDES AND PESTICIDE-APPLICATION DATA}

A total of 45 pesticides or metabolites of pesticides were detected in water from four surface-water sites in the Central Columbia Plateau study unit from March 1993 through May 1994 (table 4). There were 41 pesticides or pesticide metabolites detected in water from the two sites in the irrigated agricultural areas of the study unit, and 23 pesticides were detected in water from the two sites in the dryland agricultural areas of the study unit. Concentrations of pesticides detected at the four sites ranged from at or near the limit of detection to a maximum of $8.1 \mu \mathrm{g} / \mathrm{L}$ of DCPA at EL68D Wasteway. None of the pesticide concentrations exceeded the U.S. Environmental Protection Agency (USEPA) Maximum Contaminant Level (MCL) for drinking water (Nowell and Resek, 1994), but the freshwater-chronic criteria (table 3) for the protection of aquatic life (hereafter referred to as aquatic-life criteria) were exceeded for five pesticides (table 4).

Because of the different crop types, pesticide use, and agricultural practices in the irrigated and dryland drainage basins, pesticide and application data are summarized and presented separately for the two agricultural areas; and then data for the two areas are compared. Pesticides that were not analyzed in this study are also included with the pesticide application data to show that not all applied pesticides were analyzed, as well as to help plan for future studies.

\section{Irrigated Agricultural Drainage Basins}

Herbicides, fungicides, and insecticides are commonly applied to croplands in the two irrigated agricultural drainage basins (table 5). Of the 41 herbicides, insecticides, or pesticide metabolites that were detected in samples from EL68D Wasteway and Crab Creek Lateral, herbicides were the most frequently detected pesticides (table 6). The herbicides atrazine, DCPA, and EPTC were the most frequently detected pesticides in samples collected from the two irrigated agricultural drainage basins. Not all pesticides that were applied and analyzed for were detected, however. In some cases where the insecticide application rate was large, the frequency of detection was high; and in other cases, the frequency of detections was low (table 5). Also, in some cases where the application rate was small, the frequency of detection was observed to range from low to high (table 5). Possible explanations for these observations include the following: the accuracy of the application rates is poor; there are non-agricultural users that are not accounted for; carryover in the soil from previous years makes the application rate less meaningful; the ability to detect an analyte at a low concentration is the most important cause of frequent detections; and the rate at which an analyte breaks down is more significant than the application rate. All of these explanations, or combinations of several, provide the best understanding of the frequency of detections for any one analyte.

Concentrations of pesticides in the irrigated drainage basins did not exceed the USEPA drinking water standards, but concentrations of four insecticides did exceed the aquatic-life criteria (table 6). Concentrations in 8 samples from EL68D Wasteway exceeded the aquatic-life criteria for at least one of the three insecticides, and concentrations in 16 samples from Crab Creek Lateral exceeded the aquatic-life criteria for at least one of four pesticides (table 6). Chlorpyrifos was the insecticide that most frequently exceeded the aquatic-life criteria at both Crab Creek Lateral and EL68D Wasteway. The relation of concentrations of pesticides, corresponding streamflows, and application times is shown in figure 3 for all $22 \mathrm{com}$ pounds that were detected five or more times or exceeded aquatic-life criteria at either of the two surface-water sites located in the irrigated agricultural drainage basins. 
Table 4.--Maximum concentrations and numbers of detections of pesticides at each and all four surface-water sites in the Central Columbia Plateau, Washington and Idaho

[MDL, method detection limit; EL68D, EL68D Wasteway; CCLAT, Crab Creek Lateral; MARC, Upper Crab Creek; HOOP, Palouse River at Hooper; All, sum of all detections at all surface-water sites; $\mu \mathrm{g} / \mathrm{L}$, micrograms per liter; --, not detected. Concentrations of pesticides in bold represent values that exceed freshwater-chronic criteria for protection of aquatic life (see table 3)]

\begin{tabular}{|c|c|c|c|c|c|c|c|c|c|c|}
\hline \multirow[b]{3}{*}{ Pesticide } & \multirow[b]{3}{*}{$\begin{array}{l}\text { MDL } \\
(\mu \mathrm{g} / \mathrm{L})\end{array}$} & \multicolumn{4}{|c|}{ Maximum concentration } & \multicolumn{4}{|c|}{ Number of detections } & \multirow[b]{3}{*}{ All } \\
\hline & & \multicolumn{2}{|c|}{ Irrigated } & \multicolumn{2}{|c|}{ Dryland } & \multicolumn{2}{|c|}{ Irrigated } & \multicolumn{2}{|c|}{ Dryland } & \\
\hline & & $\begin{array}{l}\text { EL68D } \\
(\mu \mathrm{g} / \mathrm{L})\end{array}$ & $\begin{array}{l}\text { CCLAT } \\
(\mu \mathrm{g} / \mathrm{L})\end{array}$ & $\begin{array}{r}\text { MARC } \\
(\mu \mathrm{g} / \mathrm{L})\end{array}$ & $\begin{array}{r}\text { HOOP } \\
(\mu \mathrm{g} / \mathrm{L})\end{array}$ & EL68D & CCLAT & MARC & HOOP & \\
\hline \multicolumn{11}{|c|}{ Herbicides } \\
\hline Atrazine & ${ }^{1} 0.009$ & 0.02 & 0.05 & 0.03 & 0.2 & 25 & 29 & 2 & 23 & 79 \\
\hline DCPA & 0.002 & 8.1 & 0.99 & 0.002 & 0.006 & 25 & 21 & 1 & 12 & 59 \\
\hline Simazine & 0.005 & 0.019 & 0.073 & 0.042 & 0.069 & 11 & 18 & 6 & 21 & 56 \\
\hline EPTC & 0.002 & 0.41 & 1.8 & 0.008 & 0.012 & 25 & 20 & 1 & 7 & 53 \\
\hline Metolachlor & 0.002 & 0.019 & 0.042 & -- & 0.004 & 19 & 18 & 0 & 3 & 40 \\
\hline Terbacil $^{2}$ & 0.007 & $\mathrm{E}_{0.6}$ & ${ }^{\mathrm{E}} 0.5$ & -- & -- & 21 & 19 & 0 & 0 & 40 \\
\hline Alachlor & 0.002 & 0.3 & 0.03 & 0.01 & 0.006 & 25 & 10 & 1 & 2 & 38 \\
\hline Metribuzin & 0.004 & 0.1 & 0.022 & -- & 0.052 & 16 & 8 & 0 & 9 & 33 \\
\hline $2,4-\mathrm{D}$ & 0.035 & 1.3 & 1.7 & 0.24 & 0.15 & 12 & 13 & 2 & 3 & 30 \\
\hline Triallate & 0.001 & -- & -- & 0.65 & 0.49 & 0 & 0 & 6 & 24 & 30 \\
\hline Trifluralin & 0.002 & 0.096 & 0.01 & -- & 0.007 & 15 & 10 & 0 & 1 & 26 \\
\hline Pendimethalin & 0.004 & 0.19 & 0.016 & -- & -- & 15 & 10 & 0 & 0 & 25 \\
\hline Prometon & 0.018 & -- & 0.008 & 0.01 & 0.058 & 0 & 2 & 1 & 17 & 20 \\
\hline Ethalfluralin & 0.004 & 0.038 & 0.028 & -- & 0.013 & 7 & 5 & 0 & 1 & 13 \\
\hline Diuron & 0.02 & 0.33 & 0.39 & 0.07 & 0.47 & 5 & 2 & 1 & 2 & 10 \\
\hline Cyanazine & 0.004 & 0.04 & 0.014 & -- & -- & 6 & 3 & 0 & 0 & 9 \\
\hline Butylate & 0.002 & 0.006 & 0.007 & -- & -- & 6 & 3 & 0 & 0 & 9 \\
\hline Bentazon & 0.014 & 0.14 & 0.11 & -- & -- & 3 & 5 & 0 & 0 & 8 \\
\hline MCPA & 0.05 & -- & -. & -- & 0.24 & 0 & 0 & 0 & 5 & 5 \\
\hline Tebuthiuron & 0.01 & -- & 0.028 & -- & 0.01 & 0 & 1 & 0 & 4 & 5 \\
\hline Bromoxynil & 0.035 & 0.09 & -. & -- & 0.6 & 1 & 0 & 0 & 2 & 3 \\
\hline Napropamide & 0.003 & 0.007 & 0.017 & -- & -- & 1 & 2 & 0 & 0 & 3 \\
\hline Desethyl atrazine ${ }^{2.3}$ & 0.002 & $\mathrm{E}_{0.003}$ & ${ }^{E} 0.006$ & -- & ${ }^{E_{0}} 0.001$ & 1 & 1 & 0 & 1 & 3 \\
\hline Propanil & 0.004 & -- & 0.014 & -- & -- & 0 & 2 & 0 & 0 & 2 \\
\hline Linuron & 0.002 & 0.009 & 0.022 & -- & - & 1 & 1 & 0 & 0 & 2 \\
\hline Propham & 0.035 & 0.06 & -- & -- & -- & 1 & 0 & 0 & 0 & 1 \\
\hline Thiobencarb & 0.002 & -- & 0.005 & -- & -- & 0 & 1 & 0 & 0 & 1 \\
\hline Propachlor & 0.007 & -. & 0.002 & -- & -- & 0 & 1 & 0 & 0 & 1 \\
\hline \multirow[t]{2}{*}{ Benfluralin } & 0.002 & -- & 0.003 & -- & -- & 0 & 1 & 0 & 0 & 1 \\
\hline & & Numbe & of sample & analyzed & & 29 & 29 & 19 & 27 & 104 \\
\hline
\end{tabular}


Table 4.--Maximum concentrations and numbers of detections of pesticides at each and all four surface-water sites in the Central Columbia Plateau, Washington and Idaho--Continued

\begin{tabular}{|c|c|c|c|c|c|c|c|c|c|c|}
\hline \multirow[b]{3}{*}{ Pesticide } & \multirow[b]{3}{*}{$\begin{array}{l}\mathrm{MDL} \\
(\mu \mathrm{g} / \mathrm{L})\end{array}$} & \multicolumn{4}{|c|}{ Maximum concentration } & \multicolumn{4}{|c|}{ Number of detections } & \multirow[b]{3}{*}{ All } \\
\hline & & \multicolumn{2}{|c|}{ Irrigated } & \multicolumn{2}{|c|}{ Dryland } & \multicolumn{2}{|c|}{ Irrigated } & \multicolumn{2}{|c|}{ Dryland } & \\
\hline & & $\begin{array}{l}\text { EL68D } \\
(\mu \mathrm{g} / \mathrm{L})\end{array}$ & $\begin{array}{c}\text { CCLAT } \\
(\mu \mathrm{g} / \mathrm{L})\end{array}$ & $\begin{array}{r}\text { MARC } \\
(\mu \mathrm{g} / \mathrm{L})\end{array}$ & $\begin{array}{r}\mathrm{HOOP} \\
(\mu \mathrm{g} / \mathrm{L})\end{array}$ & EL68D & CCLAT & MARC & HOOP & \\
\hline \multicolumn{11}{|c|}{ Insecticides } \\
\hline Chlorpyrifos & 0.004 & 0.066 & 0.12 & - & -- & 13 & 15 & 0 & 0 & 28 \\
\hline Propargite & 0.013 & 1.4 & 0.12 & -- & -- & 16 & 4 & 0 & 0 & 20 \\
\hline Azinphos-methyl ${ }^{2}$ & 0.001 & $\mathbf{E}_{0.5}$ & $\mathbf{E}_{0.2}$ & $\mathbf{E}_{0.04}$ & -- & 3 & 12 & 1 & 0 & 16 \\
\hline Carbofuran $^{2}$ & 0.003 & $\mathrm{E}_{0.1}$ & $\mathrm{E}_{0.006}$ & -- & -- & 11 & 1 & 0 & 0 & 12 \\
\hline Ethoprop & 0.003 & 0.007 & 0.12 & -- & 0.005 & 4 & 5 & 0 & 2 & 11 \\
\hline Carbaryl $^{2}$ & 0.003 & $\mathrm{E}_{0.004}$ & $\mathbf{E}_{0.1}$ & $\mathrm{E}_{0.02}$ & -- & 1 & 8 & 2 & 0 & 11 \\
\hline gamma-HCH & 0.004 & -- & -. & -- & 0.036 & 0 & 0 & 0 & 9 & 9 \\
\hline Diazinon & 0.002 & 0.052 & 0.018 & -- & 0.012 & 4 & 2 & 0 & 1 & 7 \\
\hline Malathion & 0.005 & 0.019 & 0.025 & -- & .. & 3 & 1 & 0 & 0 & 4 \\
\hline$p, p^{\prime}-\mathrm{DDE}^{3}$ & 0.006 & -- & 0.008 & -- & -- & 0 & 4 & 0 & 0 & 4 \\
\hline Fonofos & 0.003 & 0.013 & -- & -- & -- & 3 & 0 & 0 & 0 & 3 \\
\hline Dimethoate $^{4}$ & 0.004 & $\mathrm{E}_{0.08}$ & $\mathrm{E}_{0.06}$ & -- & -- & 2 & 1 & 0 & 0 & 3 \\
\hline Dieldrin & 0.001 & 0.006 & -- & -- & -- & 3 & 0 & 0 & 0 & 3 \\
\hline cis-Permethrin ${ }^{5}$ & 0.005 & -- & $\mathrm{E}_{0.01}$ & -. & -- & 0 & 1 & 0 & 0 & 1 \\
\hline alpha-HCH & 0.002 & -- & -- & -- & 0.007 & 0 & 0 & 0 & 1 & 1 \\
\hline \multirow[t]{2}{*}{ Disulfoton } & 0.017 & 0.035 & -. & -- & -- & 1 & 0 & 0 & 0 & 1 \\
\hline & & \multicolumn{3}{|c|}{ Number of samples analyzed } & & 29 & 29 & 19 & 27 & 104 \\
\hline
\end{tabular}

${ }^{1}$ Estimated reporting level due to bias in concentrations of atrazine in field and equipment blanks (see section titled Results of Quality-Control Samples).

${ }^{2}$ Concentrations for these pesticides are qualitatively identified and reported with an $\mathrm{E}$ code (estimated value) because of problems with gas chromatography or extraction (Zaugg and others, 1995).

${ }^{3}$ Pesticide metabolite.

${ }^{4}$ Pesticide demonstrated small and variable recovery and was removed from the method schedule in November 1994.

${ }^{5}$ Field-matrix spikes demonstrated small and variable recoveries, and concentrations for this analyte are qualitatively identified and reported with an $E$ code (estimated value).

${ }^{\mathrm{E}}$ Concentration is an estimated value because of problems with gas chromatography or extraction (Zaugg and others, 1995). 
Table 5.--Amounts of pesticides applied to cropland and the number of detections of target analytes in four drainage basins in the Central Columbia Plateau, Washington and Idaho

[lb/yr, pound per year; NA, not analyzed; --, no data. Pesticides are included if they make up 1 percent or more of the total applied within each type classification. Applications were computed by multiplying crop acreages times pesticide application rates for individual crops. Crop acreages are from table 2. Pesticide application rates are from Anderson and Gianessi (1995)]

\begin{tabular}{|c|c|c|c|c|c|}
\hline $\begin{array}{l}\text { Drainage } \\
\text { basin }\end{array}$ & $\begin{array}{l}\text { Type of } \\
\text { pesticide }\end{array}$ & Pesticide & $\begin{array}{l}\text { Amount } \\
\text { applied } \\
\text { (lb/yr) }\end{array}$ & $\begin{array}{l}\text { Percent of } \\
\text { pesticides } \\
\text { applied, } \\
\text { by type }\end{array}$ & $\begin{array}{l}\text { Number of } \\
\text { detections }\end{array}$ \\
\hline
\end{tabular}

\section{Crab Creek Lateral (56 square miles) \\ (29 samples)}

Crab Creek Lateral (29 samples)

Fungicide

Sulfur

Mancozeb

Ziram

Chlorothalonil

Iprodione

Copper

Maneb

Metiram

Captan

Streptomycin

Myclobutanil

Benomyl

Dodine

Metalaxyl

Thiabendazole

Other

Herbicide

EPTC

DCPA

2,4-D

Bentazon

Alachlor

Terbacil

Metribuzin

Diuron

Glyphosate

Metolachlor

Pendimethalin

Trifluralin

Linuron

Bromoxynil

Atrazine

Simazine

Paraquat

Oxyfluorfen

MCPA

Clopyralid

2,4-DB
7,800

3,600

2,500

970

710

520

520

460

390

350

300

290

280

240

220

350

6,800

1,900

1,900

1,760

1,600

1,400

1,400

1,300

1,200

980

910

910

810

720

630

630

620

400

380

310

290

\section{0}

18

13

5

4

3

3

2

2

2

2

\section{1}

\section{1}

\section{1}

1

2

23

7

6

6

5

5

5

4

4

3

3

3

3

2

2

2

2

1

1

1
NA

NA

NA

0

NA

NA

NA

NA

NA

NA

NA

NA

NA

NA

NA

--

20

21

13

5

10

19

8

2

NA

8

10

10

1

0

29

18

NA

NA

0

0

0 
Table 5.--Amounts of pesticides applied to cropland and the number of detections of target analytes in four drainage basins in the Central Columbia Plateau, Washington and Idaho--Continued

\begin{tabular}{|c|c|c|c|c|c|}
\hline $\begin{array}{l}\text { Drainage } \\
\text { basin }\end{array}$ & $\begin{array}{l}\text { Type of } \\
\text { pesticide }\end{array}$ & Pesticide & $\begin{array}{l}\text { Amount } \\
\text { applied } \\
\text { (lb/yr) }\end{array}$ & $\begin{array}{l}\text { Percent of } \\
\text { pesticides } \\
\text { applied, } \\
\text { by type }\end{array}$ & $\begin{array}{l}\text { Number of } \\
\text { detections }\end{array}$ \\
\hline
\end{tabular}

$\underline{\text { Irrigated Agricultural Drainage Basins--Continued }}$

Crab Creek Lateral

--Continued
Crab Creek Lateral (29 samples)
Crab Creek Lateral (29 samples)
Herbicide

Ethalfluralin

Pronamide

Norflurazon

Oryzalin

Cyanazine

Diclofop-methyl

Triallate

Other

Insecticide ${ }^{1}$

Chlorpyrifos

Propargite

Azinphos-methyl

Disulfoton

Carbaryl

Endosulfan

Methyl parathion

Methamidophos

Malathion

Phorate

Phosmet

Fonofos

Oxamyl

Acephate

Methoxychlor

Ethoprop

Aldicarb

Diazinon

Dimethoate

Ethion

Permethrin

Methomyl

Oxythioquinox

Dicofol

Other

Mixed

usage or

other

chemical
210

210

190

190

190

180

160

780

4,800

4,200

3,800

2,300

2,200

1,600

1,500

1,400

1,400

1,200

1,200

1,100

1,100

950

930

900

700

510

390

350

310

270

260

190

570

1,3-Dichloropropene $\quad 110,000$

68,000

20,000

6,500

1,100

\section{5}

0

0

0

3

NA

0

--

15

4

12

0

8

NA

0

NA

1

0

NA

0

0

NA

NA

5

0

2

1

NA

0

0

NA

NA

--

NA

NA

NA

NA 
Table 5.--Amounts of pesticides applied to cropland and the number of detections of target analytes in four drainage basins in the Central Columbia Plateau, Washington and Idaho--Continued

\begin{tabular}{|c|c|c|c|c|c|}
\hline $\begin{array}{l}\text { Drainage } \\
\text { basin }\end{array}$ & $\begin{array}{l}\text { Type of } \\
\text { pesticide }\end{array}$ & Pesticide & $\begin{array}{l}\text { Amount } \\
\text { applied } \\
\text { (lb/yr) }\end{array}$ & $\begin{array}{l}\text { Percent of } \\
\text { pesticides } \\
\text { applied, } \\
\text { by type }\end{array}$ & $\begin{array}{l}\text { Number of } \\
\text { detections }\end{array}$ \\
\hline
\end{tabular}

Irrigated Agricultural Drainage Basins--Continued

\section{EL68D Wasteway}

(146 square miles)

(29 samples)
EL68D Wasteway

(29 samples)
Fungicide

Sulfur
Mancozeb

Chlorothalonil

Maneb

Iprodione

Metiram

Benomyl

Thiabendazole

Metalaxyl

Copper

DCNA

Other

Herbicide

EPTC

Bentazon

DCPA

Terbacil

2,4-D

Metribuzin

Pendimethalin

Alachlor

Metolachlor

Diuron

Bromoxynil

Trifluralin

Clopyralid

Paraquat

Linuron

Glyphosate

MCPA

Atrazine

Ethalfluralin

2,4-DB

Triallate

Diclofop-methyl

Oxyfluorfen

Pronamide

Diquat

Cyanazine

Other

$$
\begin{array}{r}
8,400 \\
3,500 \\
2,500 \\
1,600 \\
1,500 \\
490 \\
470 \\
380 \\
340 \\
300 \\
130 \\
220
\end{array}
$$

10,600

3,900

3,200

3,000

2,200

2,200

2,100

1,700

1,600

1,500

1,400

1,100

720

720

670

640

630

540

450

340

330

310

270

250

220

220

970

42
18
13
8
8
2
2
2
2
2
1
1

NA

NA

0

NA

NA

NA

NA

NA

NA

NA

NA

--

25

3

25

21

12

16

15

25

19

5

1

15

0

NA

1

NA

0

27

7

0

0

NA

NA

0

NA

6 
Table 5.--Amounts of pesticides applied to cropland and the number of detections of target analytes in four drainage basins in the Central Columbia Plateau, Washington and Idaho--Continued

\begin{tabular}{|c|c|c|c|c|c|}
\hline $\begin{array}{l}\text { Drainage } \\
\text { basin }\end{array}$ & $\begin{array}{l}\text { Type of } \\
\text { pesticide }\end{array}$ & Pesticide & $\begin{array}{l}\text { Amount } \\
\text { applied } \\
\text { (lb/yr) }\end{array}$ & $\begin{array}{l}\text { Percent of } \\
\text { pesticides } \\
\text { applied, } \\
\text { by type }\end{array}$ & $\begin{array}{l}\text { Number of } \\
\text { detections }\end{array}$ \\
\hline
\end{tabular}

Irrigated Agricultural Drainage Basins---Continued

\begin{tabular}{|c|c|c|c|c|c|}
\hline \multirow{21}{*}{$\begin{array}{l}\text { EL68D Wasteway } \\
\text { (29 samples) }\end{array}$} & \multirow[t]{21}{*}{ Insecticide ${ }^{1}$} & Propargite & 8,200 & 22 & 16 \\
\hline & & Methamidophos & 4,400 & 12 & NA \\
\hline & & Disulfoton & 4,400 & 12 & 1 \\
\hline & & Phorate & 3,800 & 10 & 0 \\
\hline & & Fonofos & 2,800 & 8 & 3 \\
\hline & & Ethoprop & 2,400 & 7 & 4 \\
\hline & & Acephate & 2,200 & 6 & NA \\
\hline & & Oxamyl & 2,000 & 5 & 0 \\
\hline & & Chlorpyrifos & 1,700 & 5 & 13 \\
\hline & & Aldicarb & 1,200 & 3 & 0 \\
\hline & & Diazinon & 570 & 2 & 4 \\
\hline & & Ethion & 570 & 2 & NA \\
\hline & & Dimethoate & 450 & 1 & 2 \\
\hline & & Methyl parathion & 340 & 1 & 0 \\
\hline & & Dicofol & 320 & 1 & NA \\
\hline & & Azinphos-methyl & 310 & 1 & 3 \\
\hline & & Permethrin & 280 & 1 & 0 \\
\hline & & Malathion & 230 & 1 & 3 \\
\hline & & Carbofuran & 210 & 1 & 11 \\
\hline & & Parathion & 190 & 1 & 0 \\
\hline & & Other & 630 & 2 & -- \\
\hline \multirow{5}{*}{$\begin{array}{l}\text { EL68D Wasteway } \\
\text { (29 samples) }\end{array}$} & \multirow{5}{*}{$\begin{array}{l}\text { Mixed } \\
\text { usage or } \\
\text { other } \\
\text { chemical }\end{array}$} & 1,3-Dichloropropene & 250,000 & 46 & NA \\
\hline & & Metam sodium & 210,000 & 38 & NA \\
\hline & & Sulfuric acid & 62,000 & 11 & NA \\
\hline & & Chloropicrin & 20,000 & 4 & NA \\
\hline & & Other & 2,100 & 0 & \\
\hline
\end{tabular}

Dryland Agricultural Drainage Basins

\begin{tabular}{|c|c|c|c|c|c|}
\hline 3. Upper Crab Creek & Fungicide & Thiabendazole & 4,800 & 46 & NA \\
\hline (384 square miles) & & Benomyl & 4,400 & 42 & NA \\
\hline (19 samples) & & Thiophanate-methyl & 1,200 & 11 & NA \\
\hline
\end{tabular}


Table 5.--Amounts of pesticides applied to cropland and the number of detections of target analytes in four drainage basins in the Central Columbia Plateau, Washington and Idaho--Continued

\begin{tabular}{lllll}
\hline & & & Percent of \\
& & $\begin{array}{l}\text { Amount } \\
\text { pesticides }\end{array}$ & \\
$\begin{array}{l}\text { Drainage } \\
\text { basin }\end{array}$ & $\begin{array}{l}\text { Type of } \\
\text { pesticide }\end{array}$ & Pesticide & applied, & $\begin{array}{l}\text { Number of } \\
\text { by typetections }\end{array}$ \\
\hline
\end{tabular}

Dryland Agricultural Drainage Basins--Continued

\begin{tabular}{|c|c|c|c|c|c|}
\hline Upper Crab Creek & Herbicide & Glyphosate & 43,000 & 34 & NA \\
\hline (19 samples) & & $2,4-\mathrm{D}$ & 30,000 & 24 & 2 \\
\hline & & Diuron & 16,000 & 13 & 1 \\
\hline & & MCPA & 11,000 & 9 & 0 \\
\hline & & Bromoxynil & 7,800 & 6 & 0 \\
\hline & & Diclofop-methyl & 4,000 & 3 & NA \\
\hline & & Paraquat & 3,300 & 3 & NA \\
\hline & & Triallate & 3,000 & 2 & 6 \\
\hline & & M^tribuzin & 1,900 & 2 & 0 \\
\hline & & Dicamba & 1,700 & 1 & 0 \\
\hline & & Difenzoquat & 990 & 1 & NA \\
\hline & & Trifluralin & 700 & 1 & 0 \\
\hline & & Other & 1,500 & 1 & -- \\
\hline Upper Crab Creek & Insecticide & Disulfoton & 2,900 & 57 & 0 \\
\hline (19 samples) & & Parathion & 980 & 19 & 0 \\
\hline & & Dimethoate & 750 & 14 & 0 \\
\hline & & Methyl parathion & 490 & 9 & 0 \\
\hline & & Other & 26 & 1 & -- \\
\hline 4. Palouse River & Fungicide & Thiabendazole & 23,000 & 46 & NA \\
\hline (2,500 square miles) & & Benomyl & 21,000 & 42 & NA \\
\hline (27 samples) & & Thiophanate-methyl & 5,700 & 11 & NA \\
\hline & & Other & 100 & 0 & -- \\
\hline Palouse River & Herbicide & Triallate & 240,000 & 36 & 24 \\
\hline (27 samples) & & $2,4-\mathrm{D}$ & 100,000 & 16 & 3 \\
\hline & & Diuron & 80,000 & 12 & 2 \\
\hline & & Imazethapyr & 37,000 & 6 & NA \\
\hline & & Bromoxynil & 36,000 & 6 & 2 \\
\hline & & MCPA & 33,000 & 5 & 5 \\
\hline & & Glyphosate & 27,000 & 4 & NA \\
\hline & & Diclofop-methyl & 20,000 & 3 & NA \\
\hline & & Paraquat & 15,000 & 2 & NA \\
\hline & & Metribuzin & 11,000 & 2 & 9 \\
\hline & & Dicamba & 11,000 & 2 & 0 \\
\hline & & Trifluralin & 7,400 & 1 & 1 \\
\hline & & DCPA & 5,700 & 1 & 12 \\
\hline & & Ethalfluralin & 5,100 & 1 & 1 \\
\hline & & Difenzoquat & 4,800 & 1 & NA \\
\hline & & Other & 17,000 & 3 & -- \\
\hline
\end{tabular}


Table 5.--Amounts of pesticides applied to cropland and the number of detections of target analytes in four drainage basins in the Central Columbia Plateau, Washington and Idaho--Continued

\begin{tabular}{|c|c|c|c|c|c|}
\hline $\begin{array}{l}\text { Drainage } \\
\text { basin }\end{array}$ & $\begin{array}{l}\text { Type of } \\
\text { pesticide }\end{array}$ & Pesticide & $\begin{array}{l}\text { Amount } \\
\text { applied } \\
\text { (lb/yr) }\end{array}$ & $\begin{array}{l}\text { Percent of } \\
\text { pesticides } \\
\text { applied, } \\
\text { by type }\end{array}$ & $\begin{array}{l}\text { Number of } \\
\text { detections }\end{array}$ \\
\hline \multicolumn{6}{|c|}{ Dryland Agricultural Drainage Basins--Continued } \\
\hline \multirow{12}{*}{$\begin{array}{l}\text { Palouse River } \\
\text { (27 samples) }\end{array}$} & \multirow[t]{12}{*}{ Insecticide } & Disulfoton & 14,000 & 35 & 0 \\
\hline & & Dimethoate & 8,600 & 21 & 0 \\
\hline & & Phosmet & 5,700 & 14 & NA \\
\hline & & Parathion & 4,800 & 12 & 0 \\
\hline & & Methyl parathion & 2,400 & 6 & 0 \\
\hline & & Malathion & 2,000 & 5 & 0 \\
\hline & & Mevinphos & 580 & 1 & NA \\
\hline & & Chlorpyrifos & 440 & 1 & 0 \\
\hline & & Methomyl & 360 & 1 & 0 \\
\hline & & Propargite & 360 & 1 & 0 \\
\hline & & Diazinon & 210 & 1 & 1 \\
\hline & & Other & 480 & 1 & -- \\
\hline \multirow{5}{*}{$\begin{array}{l}\text { Palouse River } \\
\text { (27 samples) }\end{array}$} & \multirow{5}{*}{$\begin{array}{l}\text { Mixed } \\
\text { usage or } \\
\text { other } \\
\text { chemical }\end{array}$} & Sulfuric acid & 1,300 & 39 & NA \\
\hline & & Metam sodium & 1,300 & 37 & NA \\
\hline & & Chloropicrin & 420 & 13 & NA \\
\hline & & 1,3-Dichloropropene & 380 & 11 & NA \\
\hline & & Maleic hydrazide & 4 & 0 & NA \\
\hline
\end{tabular}

${ }^{1}$ Petroleum distillates, which often are used on orchards, are not included. 
Table 6.--Summary of pesticide concentrations from two surface-water sites located in irrigated agricultural drainage basins in the Central Columbia Plateau, Washington

$[\mathrm{H}$, herbicide; $\mathrm{I}$, insecticide; $\mathrm{M}$, metabolite; $\mu \mathrm{g} / \mathrm{L}$, micrograms per liter; $<$, less than. Pesticide concentrations in bold represent values that exceed the freshwater-chronic criteria for protection of aquatic life (see table 3)]

\begin{tabular}{|c|c|c|c|c|c|c|}
\hline \multirow[b]{2}{*}{$\begin{array}{l}\text { Compound } \\
\text { name }\end{array}$} & \multirow[b]{2}{*}{$\begin{array}{l}\text { Type of } \\
\text { pesticide }\end{array}$} & \multirow{2}{*}{$\begin{array}{l}\text { Method } \\
\text { detec- } \\
\text { tion } \\
\text { limit } \\
(\mu \mathrm{g} / \mathrm{L})\end{array}$} & \multicolumn{2}{|c|}{ Concentrations } & \multirow{2}{*}{$\begin{array}{l}\text { Number } \\
\text { of } \\
\text { detec- } \\
\text { tions }\end{array}$} & \multirow{2}{*}{$\begin{array}{l}\text { Number of } \\
\text { detections } \\
\text { that exceed } \\
\text { aquatic-life } \\
\text { criteria }\end{array}$} \\
\hline & & & $\begin{array}{l}\text { Median } \\
(\mu \mathrm{g} / \mathrm{L})\end{array}$ & $\begin{array}{l}\text { Maximum } \\
(\mu \mathrm{g} / \mathrm{L})\end{array}$ & & \\
\hline
\end{tabular}

\begin{tabular}{|c|c|c|c|c|c|c|}
\hline Atrazine & $\mathrm{H}$ & ${ }^{1} 0.009$ & 0.015 & 0.02 & 25 & 0 \\
\hline Alachlor & $\mathrm{H}$ & 0.002 & 0.013 & 0.3 & 25 & 0 \\
\hline DCPA & $\mathrm{H}$ & 0.002 & 0.066 & 8.1 & 25 & 0 \\
\hline EPTC & $\mathrm{H}$ & 0.002 & 0.012 & 0.41 & 25 & 0 \\
\hline Terbacil $^{2}$ & $\mathrm{H}$ & 0.007 & $\mathrm{E}_{0.04}$ & $\mathrm{E}_{0.6}$ & 21 & 0 \\
\hline Metolachlor & $\mathrm{H}$ & 0.002 & 0.003 & 0.019 & 19 & 0 \\
\hline Metribuzin & $\mathrm{H}$ & 0.004 & 0.007 & 0.1 & 16 & 0 \\
\hline Propargite & I & 0.013 & 0.013 & 1.4 & 16 & 0 \\
\hline Pendimethalin & $\mathrm{H}$ & 0.004 & 0.011 & 0.19 & 15 & 0 \\
\hline Trifluralin & $\mathrm{H}$ & 0.002 & 0.004 & $0.09 \epsilon$ & 15 & 0 \\
\hline Chlorpyrifos & I & 0.004 & $<0.004$ & 0.066 & 13 & 3 \\
\hline $2,4-\mathrm{D}$ & $\mathrm{H}$ & 0.035 & $<0.035$ & 1.3 & 12 & 0 \\
\hline Carbofuran $^{2}$ & I & 0.003 & $<0.003$ & $\mathrm{E}_{0.1}$ & 11 & 0 \\
\hline Simazine & $\mathrm{H}$ & 0.005 & $<0.005$ & 0.019 & 11 & 0 \\
\hline Ethalfluralin & $\mathrm{H}$ & 0.004 & $<0.004$ & 0.038 & 7 & 0 \\
\hline Butylate & $\mathrm{H}$ & 0.002 & $<0.002$ & 0.006 & 6 & 0 \\
\hline Cyanazine & $\mathrm{H}$ & 0.004 & $<0.004$ & 0.04 & 6 & 0 \\
\hline Diuron & $\mathrm{H}$ & 0.02 & $<0.02$ & 0.33 & 5 & 0 \\
\hline Diazinon & I & 0.002 & $<0.002$ & 0.052 & 4 & 3 \\
\hline Ethoprop & I & 0.003 & $<0.003$ & 0.007 & 4 & 0 \\
\hline Axinphos-methyl $^{2}$ & I & 0.001 & $<0.001$ & $\mathrm{E}_{0.5}$ & 3 & 3 \\
\hline Bentazon & $\mathrm{H}$ & 0.014 & $<0.014$ & 0.14 & 3 & 0 \\
\hline Fonofos & I & 0.003 & $<0.003$ & 0.013 & 3 & 0 \\
\hline Malathion & I & 0.005 & $<0.005$ & 0.019 & 3 & 0 \\
\hline Dieldrin & I & 0.001 & $<0.001$ & 0.006 & 3 & 0 \\
\hline Dimethoate $^{3}$ & I & 0.004 & $<0.004$ & $\mathrm{E}_{0.08}$ & 2 & 0 \\
\hline Bromoxynil & $\mathrm{H}$ & 0.035 & $<0.035$ & 0.09 & 1 & 0 \\
\hline Carbary $1^{2}$ & I & 0.003 & $<0.003$ & $\mathrm{E}_{0.004}$ & 1 & 0 \\
\hline Desethyl atrazine ${ }^{2}$ & $M$ & 0.002 & $<0.002$ & $E_{0.003}$ & 1 & 0 \\
\hline Disulfoton & I & 0.017 & $<0.017$ & 0.035 & 1 & 0 \\
\hline Linuron & $\mathrm{H}$ & 0.002 & $<0.002$ & 0.009 & 1 & 0 \\
\hline Napropamide & $\mathrm{H}$ & 0.003 & $<0.003$ & 0.007 & 1 & 0 \\
\hline Propham & $\mathrm{H}$ & 0.035 & $<0.035$ & 0.06 & 1 & 0 \\
\hline
\end{tabular}

Crab Creek Lateral (29 samples)

$\begin{array}{lllllll}\text { Atrazine } & \mathrm{H} & { }^{1} 0.009 & 0.02 & 0.05 & 29 & 0 \\ \text { DCPA } & \mathrm{H} & 0.002 & 0.06 & 0.99 & 21 & 0 \\ \text { EPTC } & \mathrm{H} & 0.002 & 0.02 & 1.8 & 20 & 0 \\ \text { Terbacil }^{2} & \mathrm{H} & 0.007 & \mathrm{E}_{0.04} & \mathrm{E}_{0.5} & 19 & 0\end{array}$


Table 6.--Summary of pesticide concentrations from two surface-water sites located in irrigated agricultural drainage basins in the Central Columbia Plateau, Washington--Continued

\begin{tabular}{|c|c|c|c|c|c|c|}
\hline \multirow[b]{2}{*}{$\begin{array}{l}\text { Compound } \\
\text { name }\end{array}$} & \multirow[b]{2}{*}{$\begin{array}{l}\text { Type of } \\
\text { pesticide }\end{array}$} & \multirow{2}{*}{$\begin{array}{l}\text { Method } \\
\text { detec- } \\
\text { tion } \\
\text { limit } \\
(\mu \mathrm{g} / \mathrm{L})\end{array}$} & \multicolumn{2}{|c|}{ Concentrations } & \multirow{2}{*}{$\begin{array}{l}\text { Number } \\
\text { of } \\
\text { detec- } \\
\text { tions }\end{array}$} & \multirow{2}{*}{$\begin{array}{l}\text { Number of } \\
\text { detections } \\
\text { that exceed } \\
\text { aquatic-life } \\
\text { criteria }\end{array}$} \\
\hline & & & $\begin{array}{l}\text { Median } \\
(\mu \mathrm{g} / \mathrm{L})\end{array}$ & $\begin{array}{l}\text { Maximum } \\
(\mu \mathrm{g} / \mathrm{L})\end{array}$ & & \\
\hline
\end{tabular}

Crab Creek Lateral (29 samples)--Continued

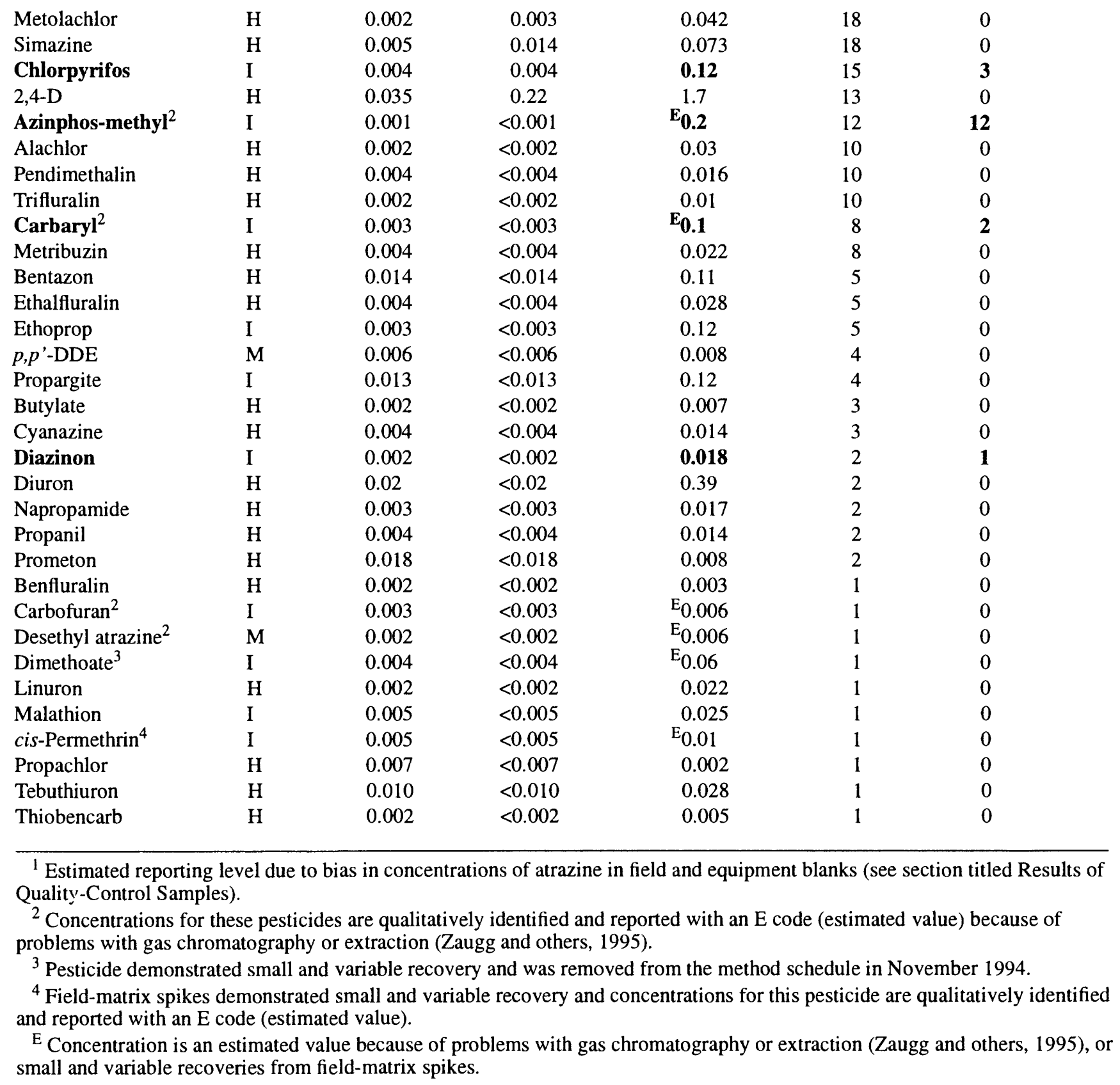




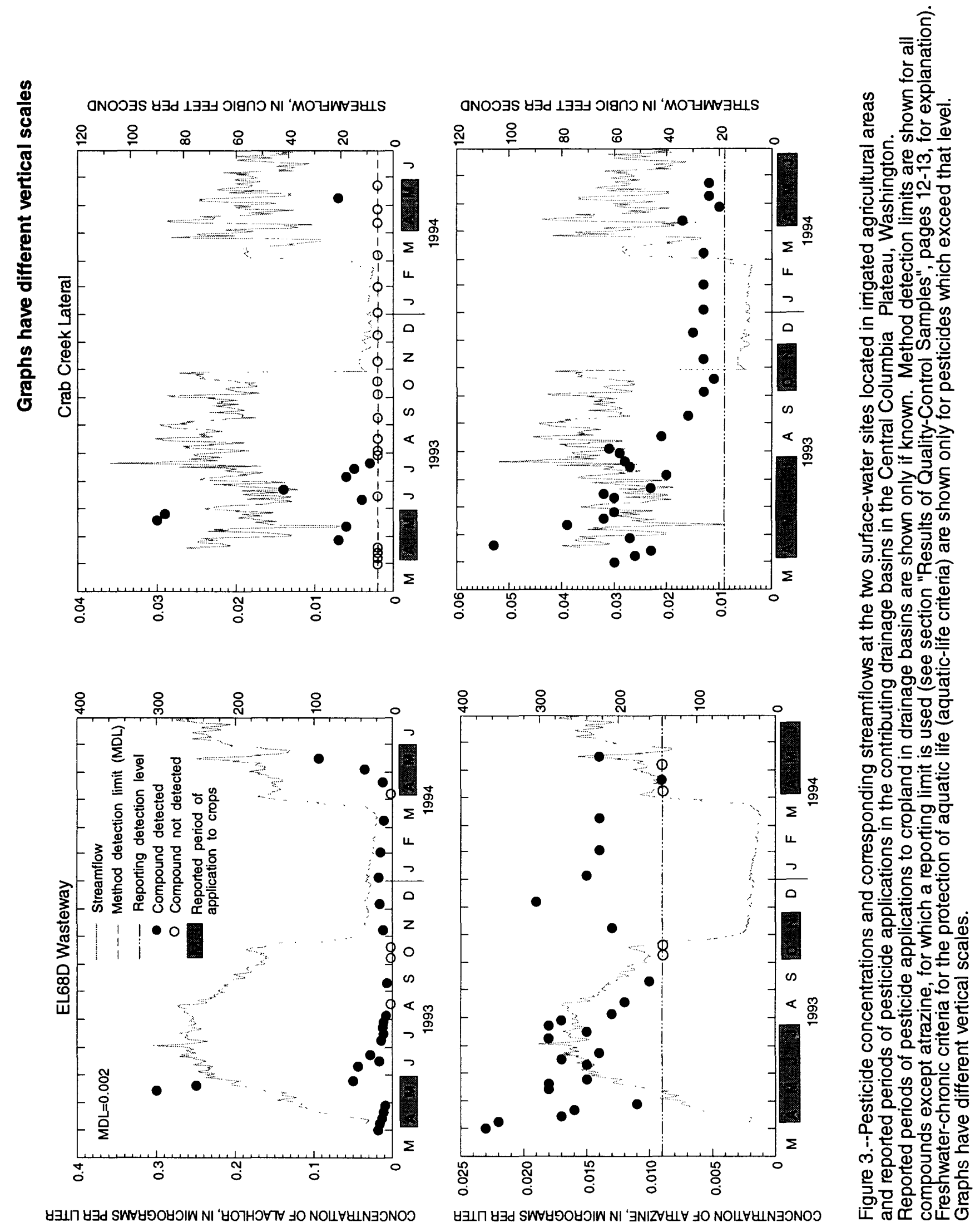



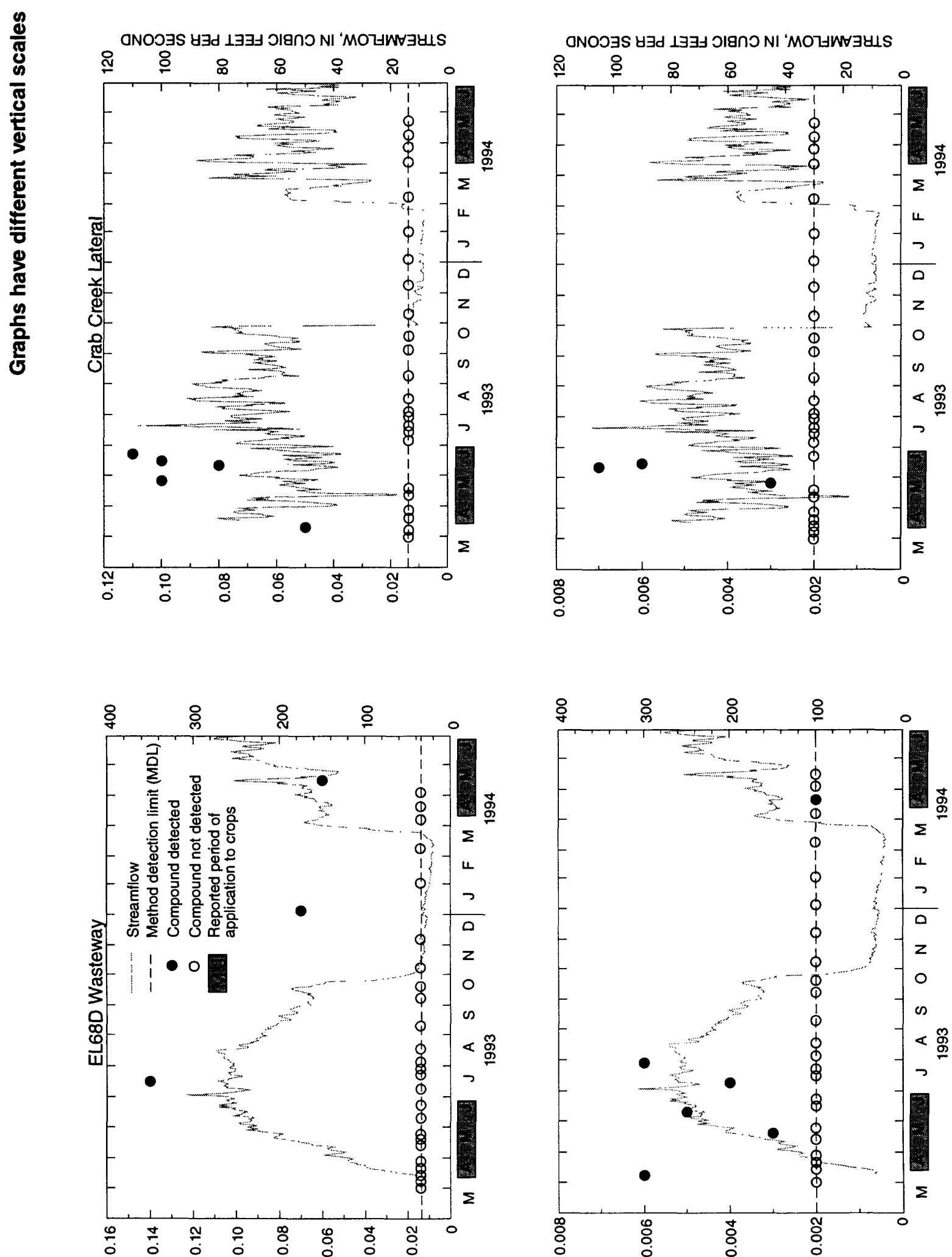

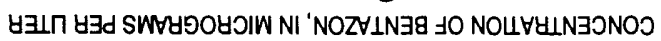

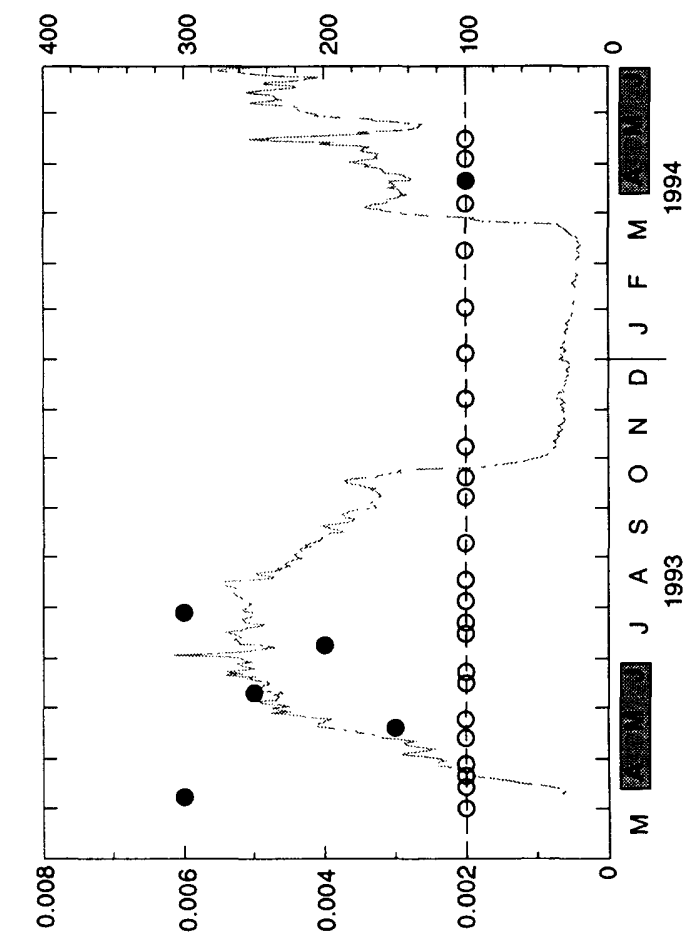

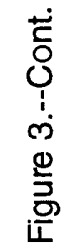




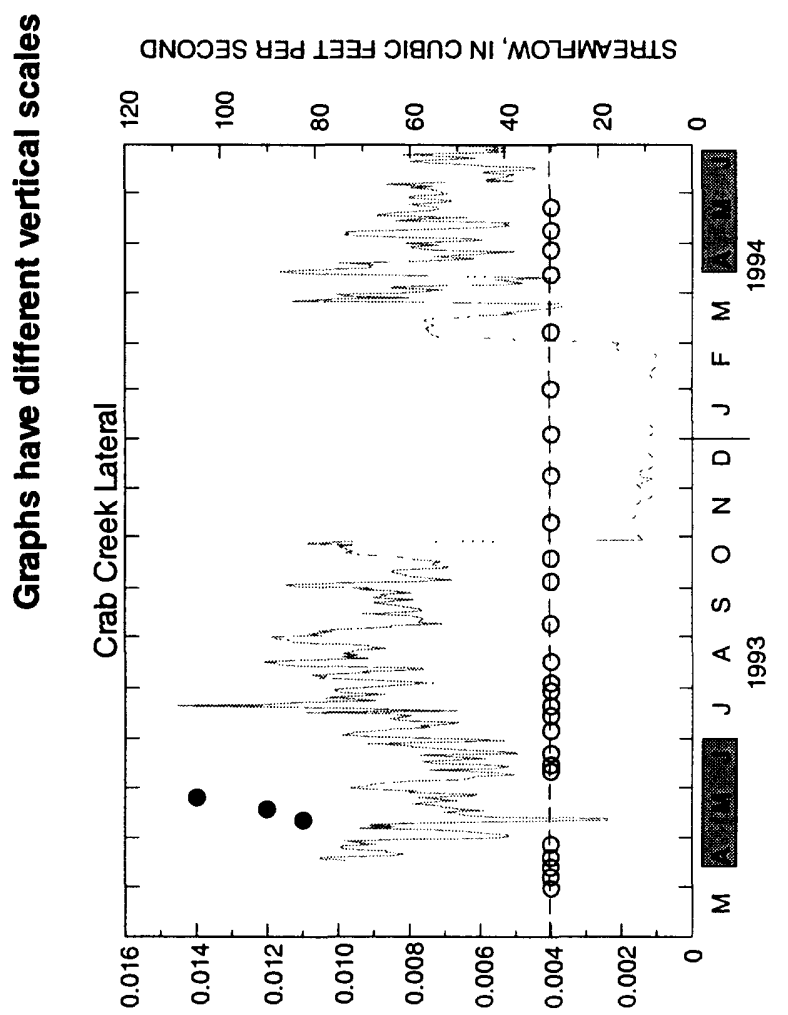

aNOOتS Y

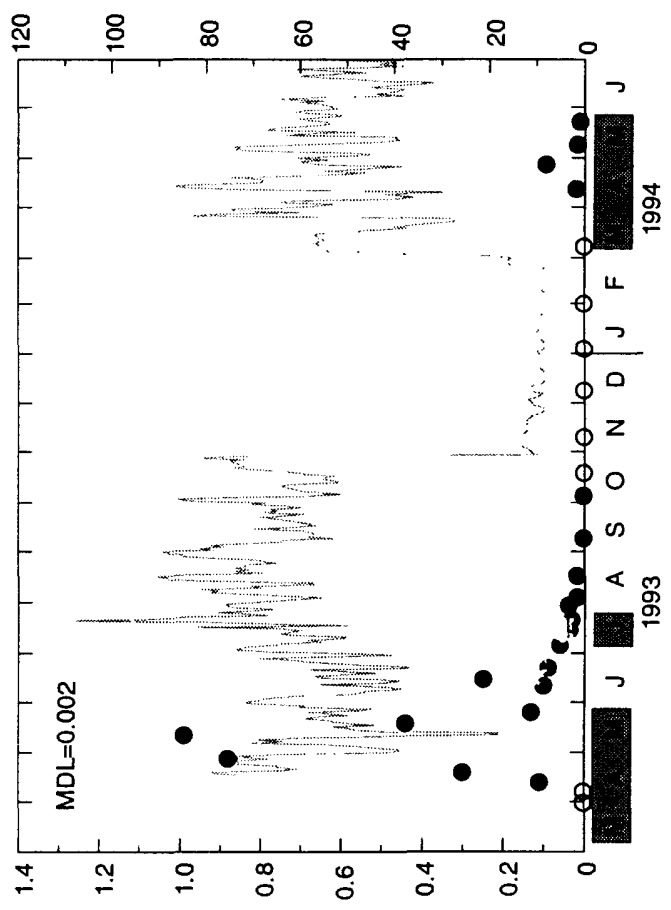

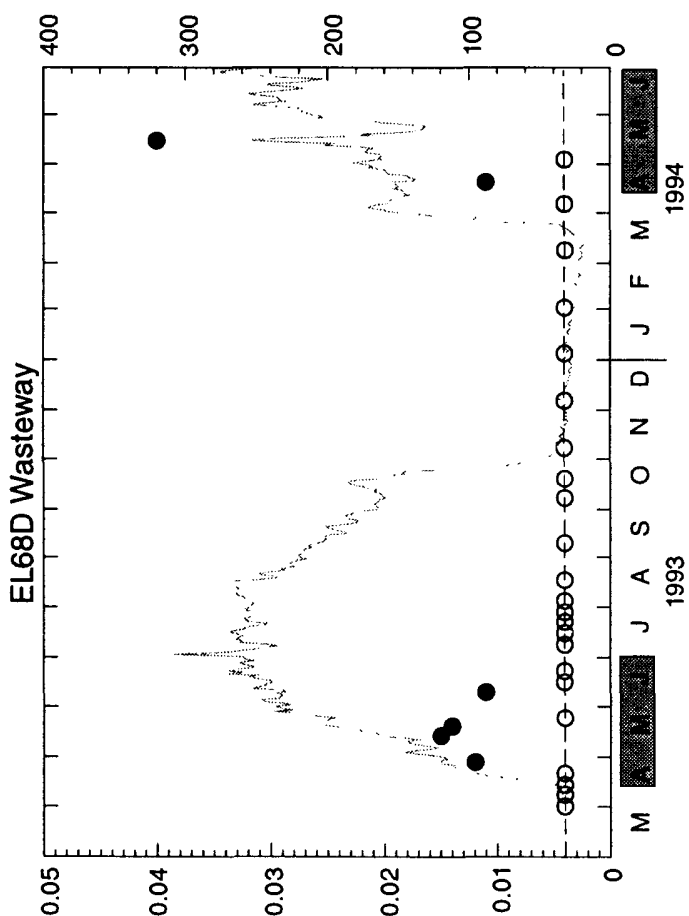

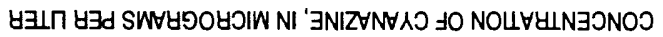

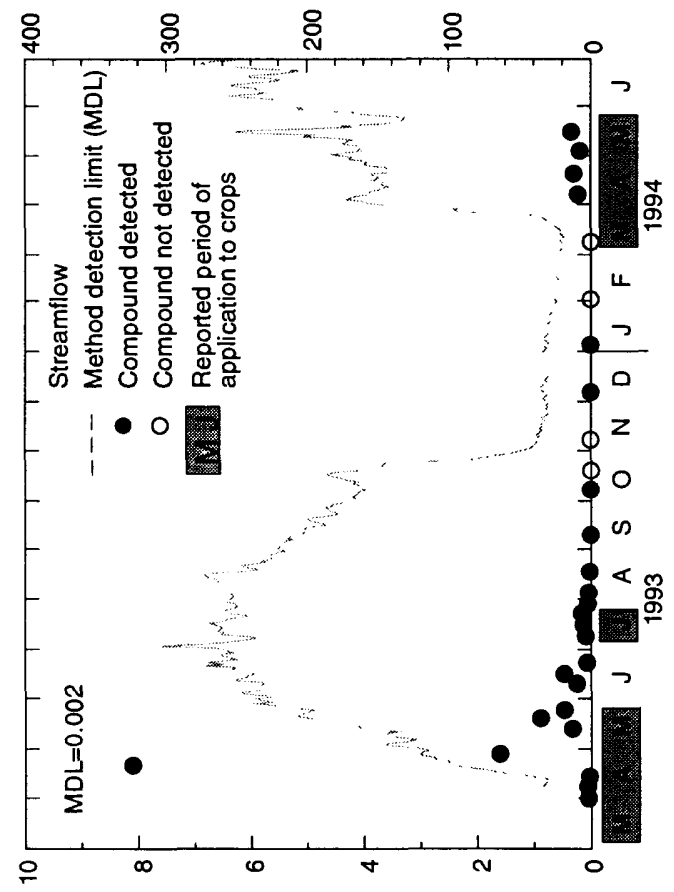

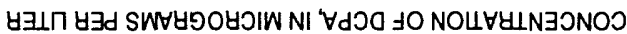



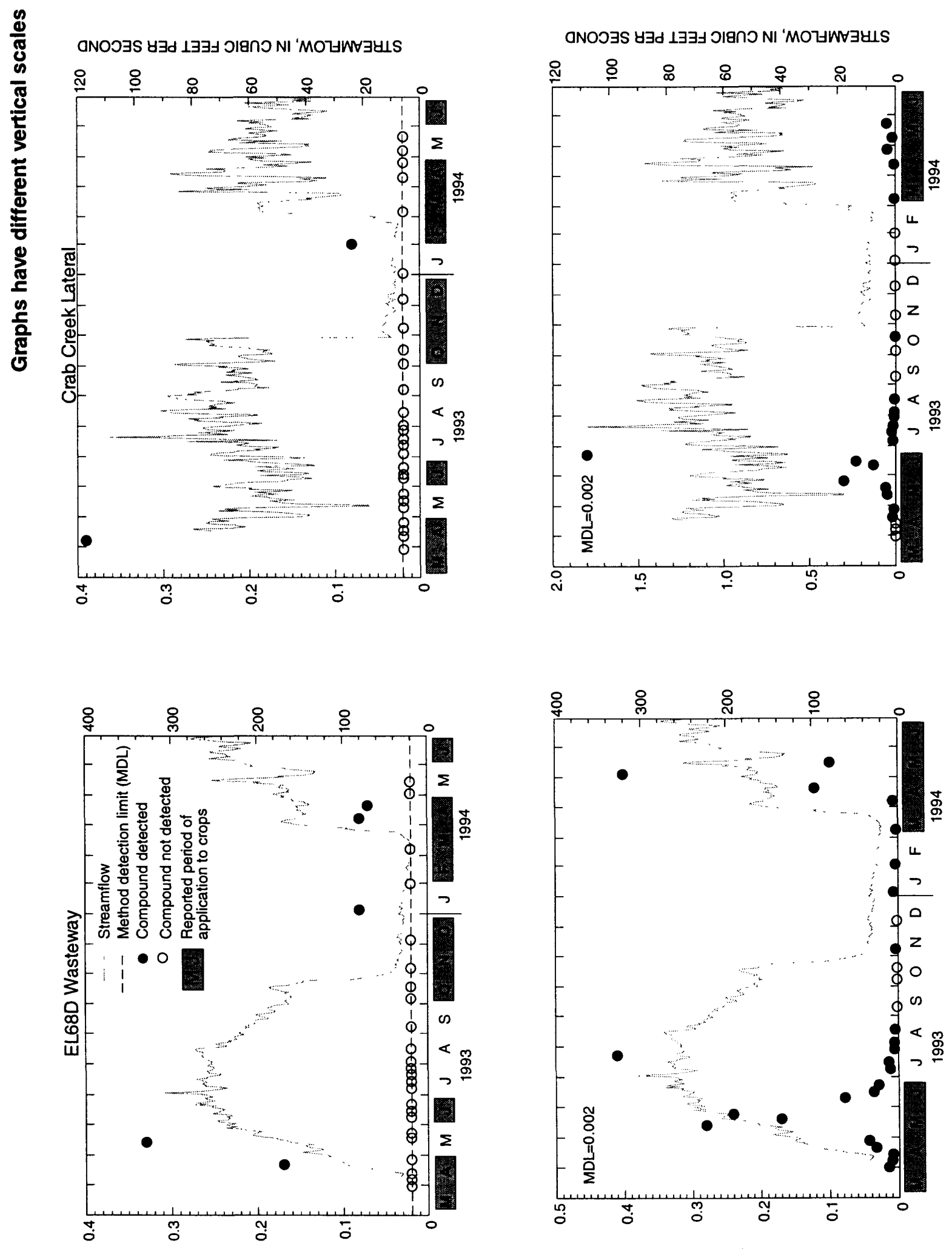

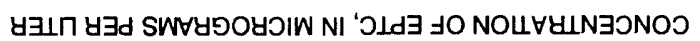

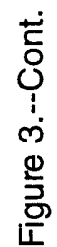



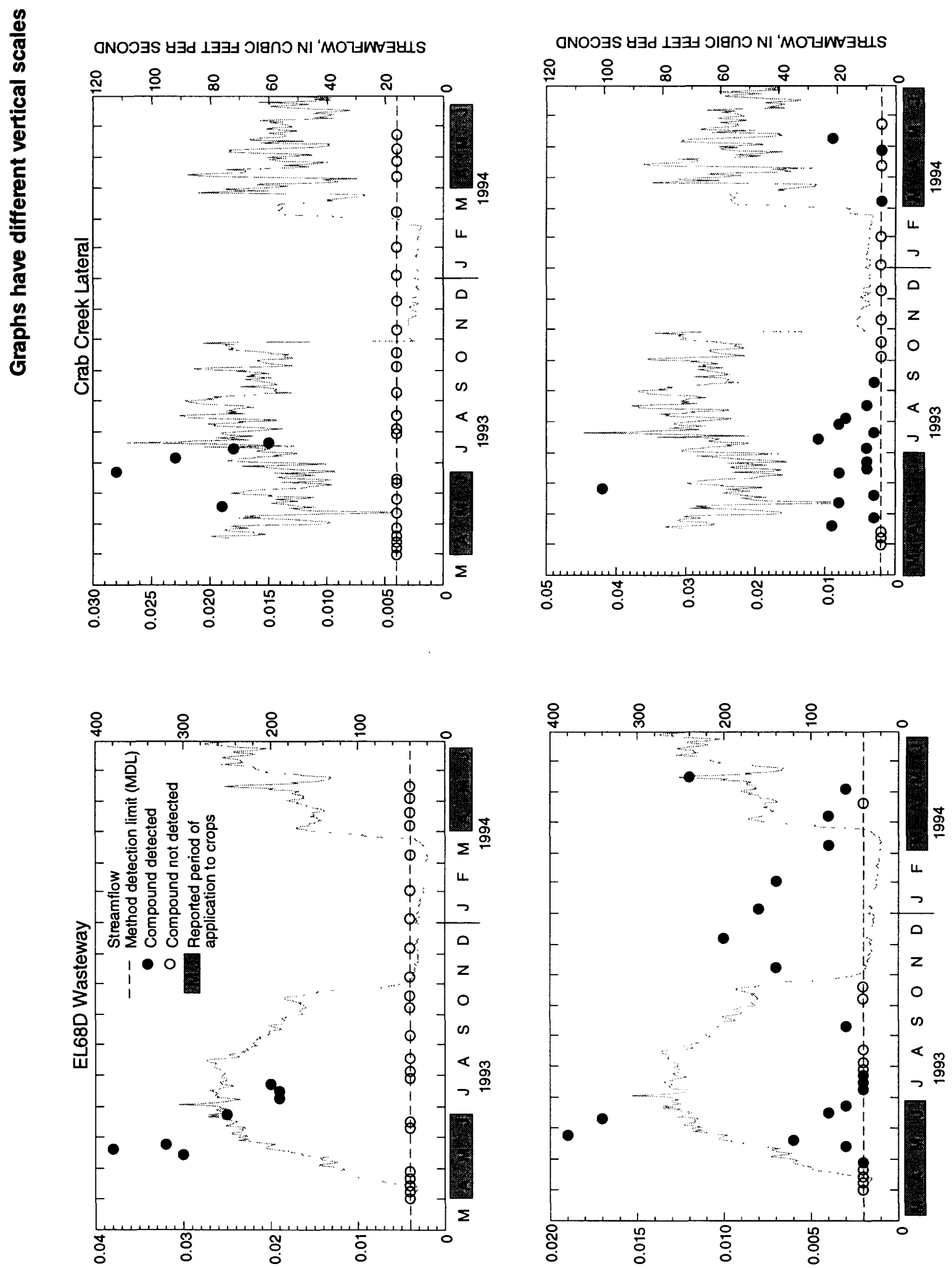

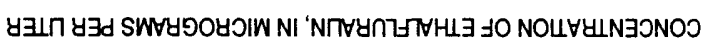

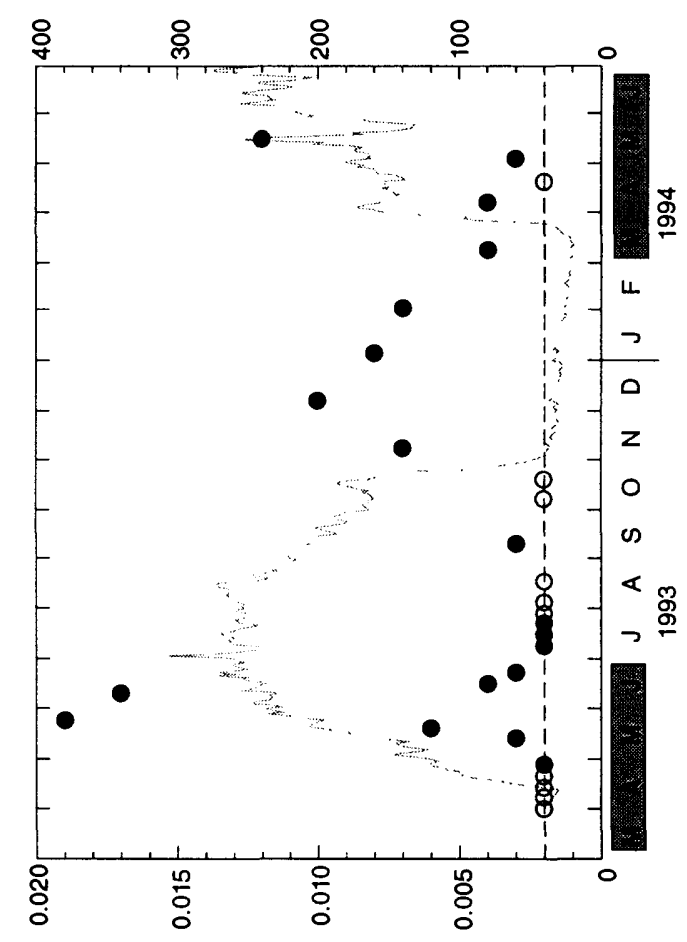

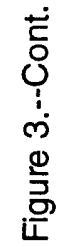



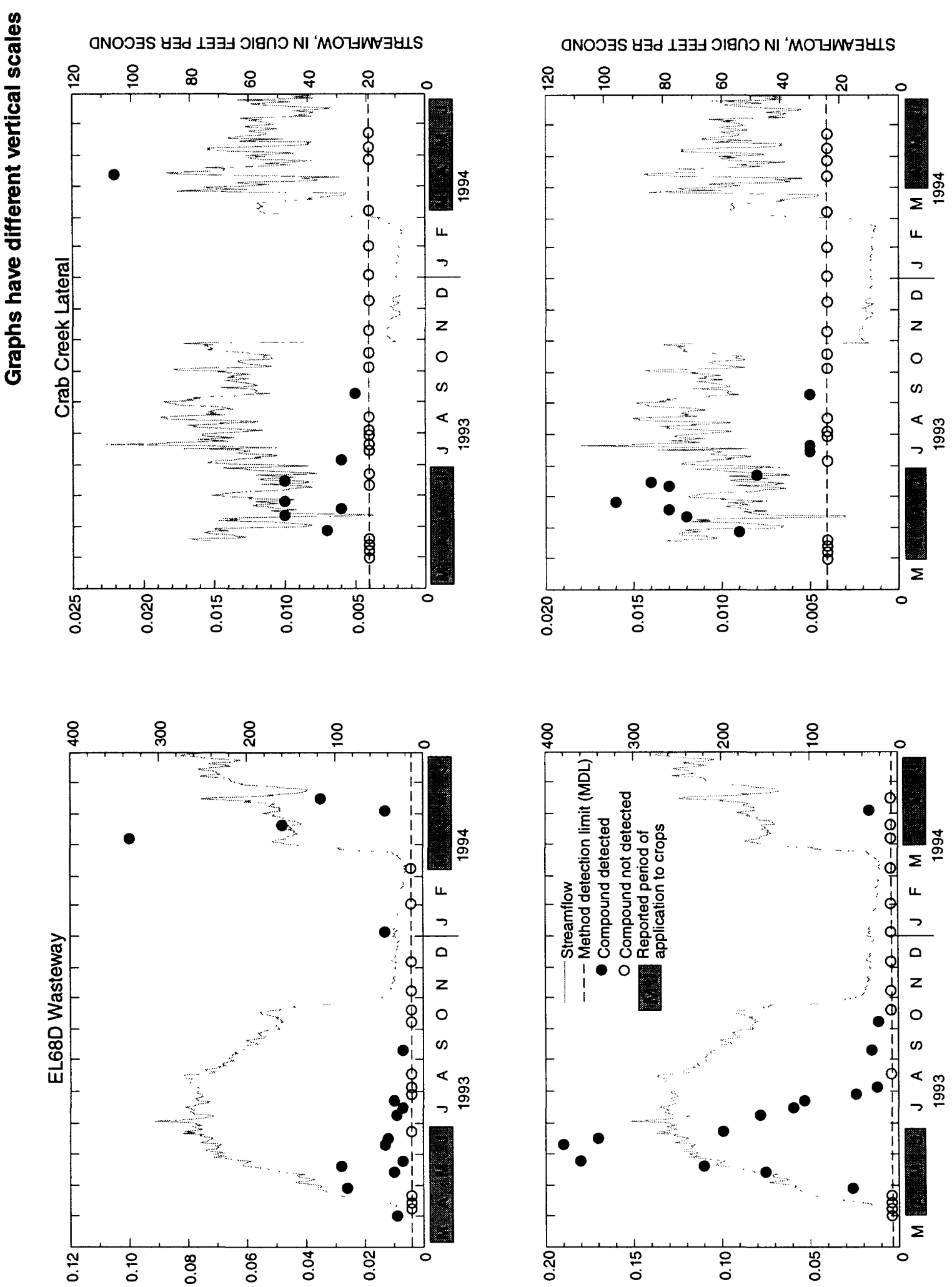

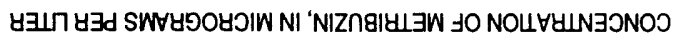

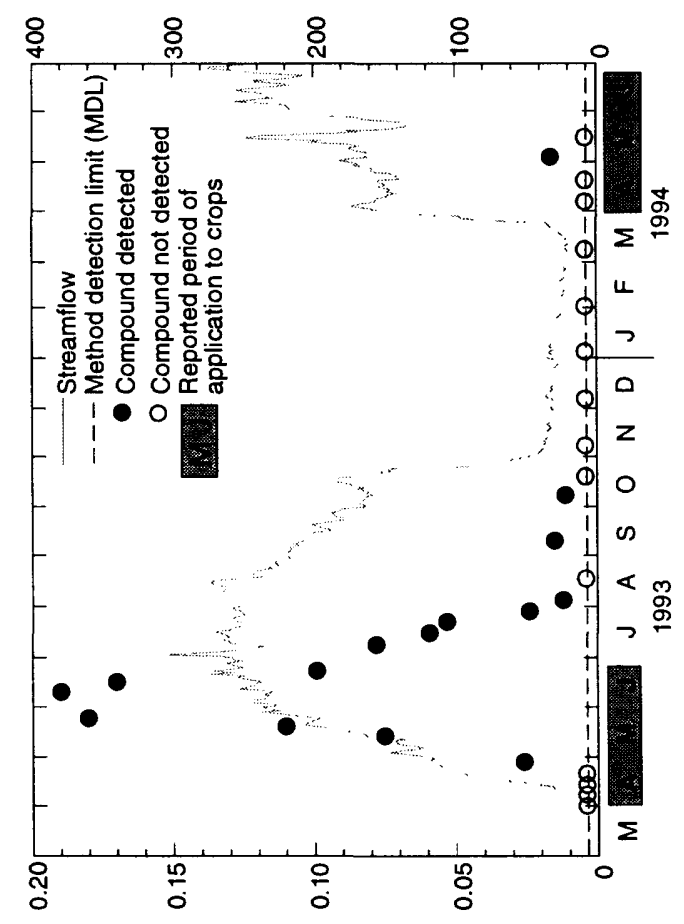

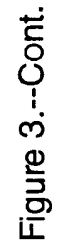



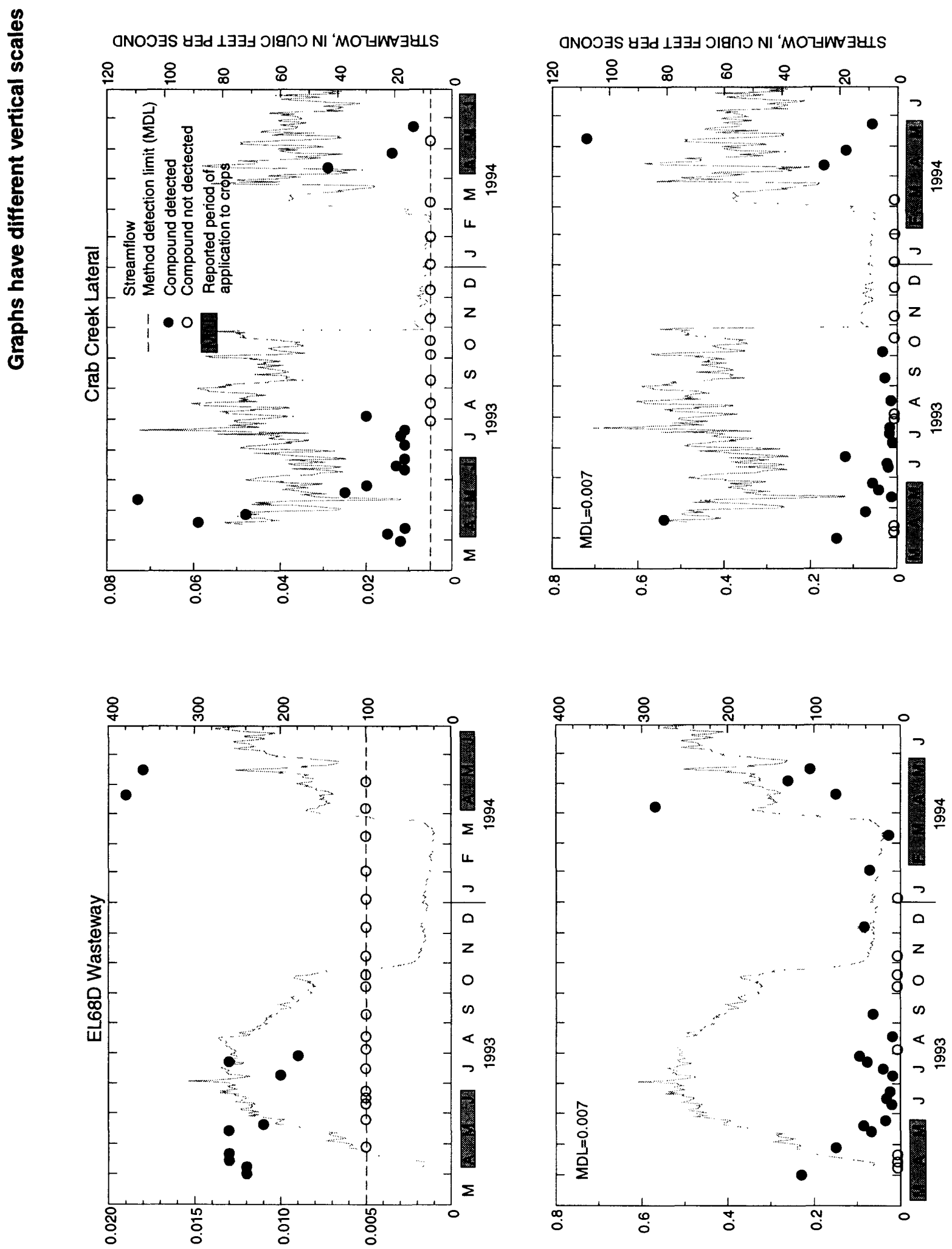

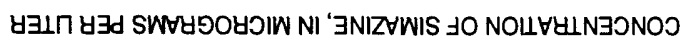

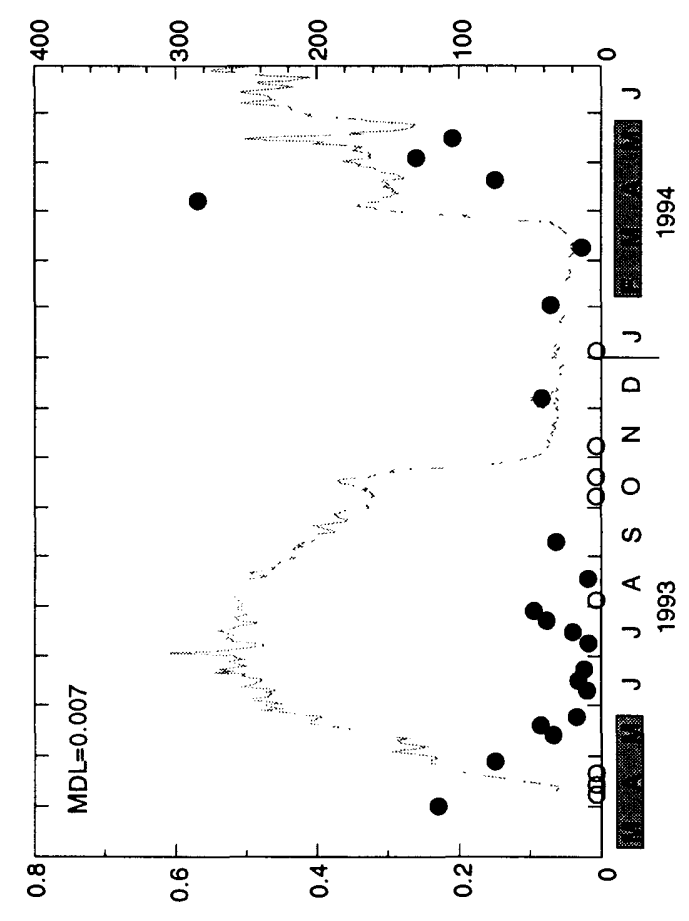

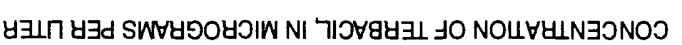

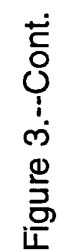




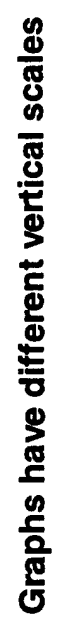

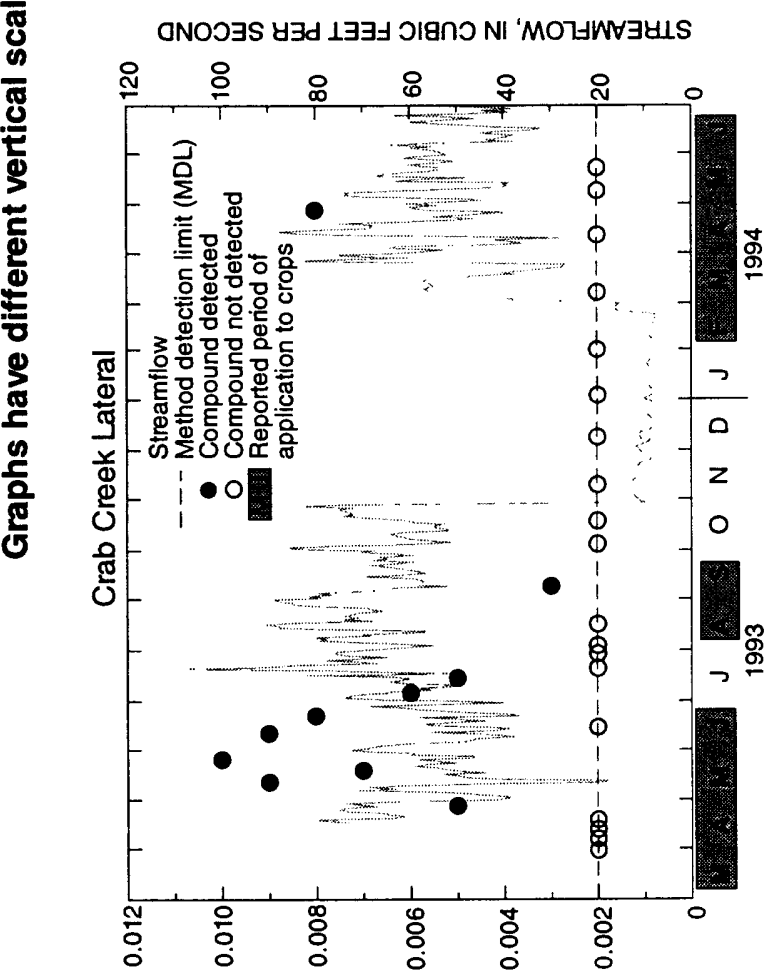

GNOJ
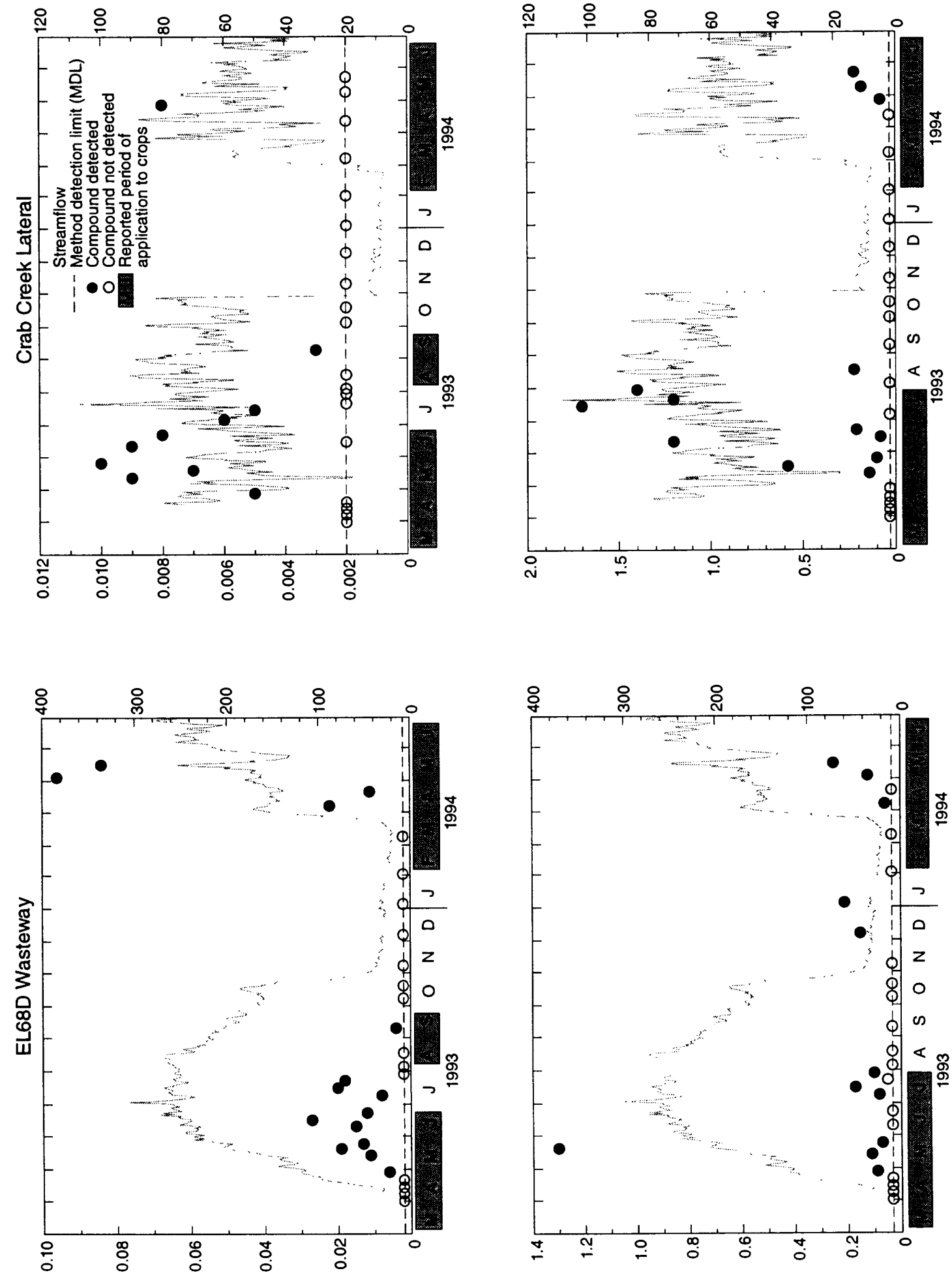

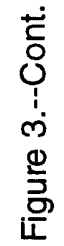




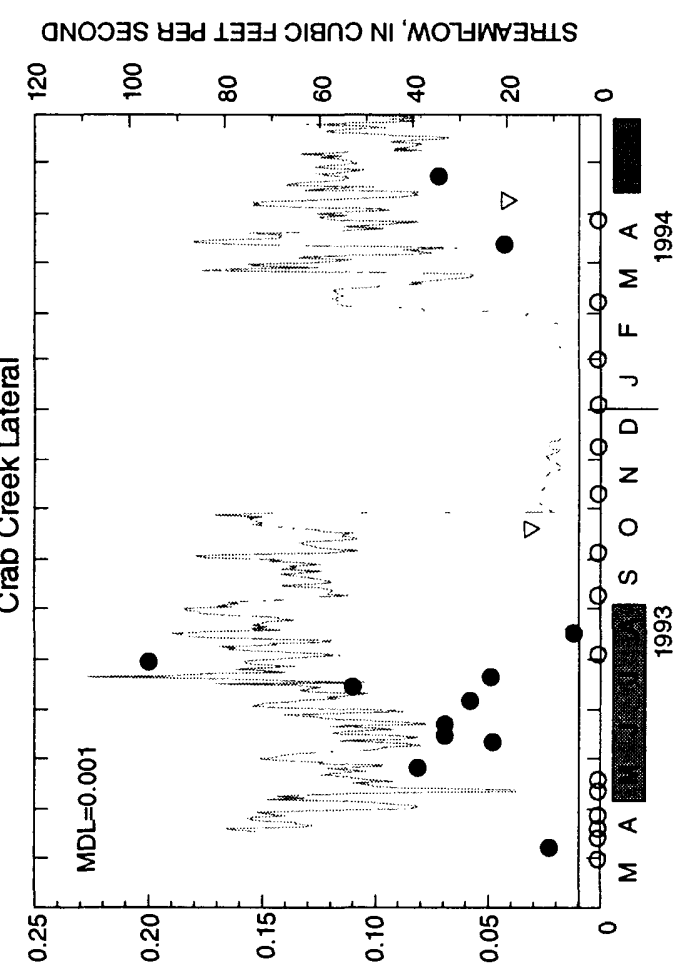

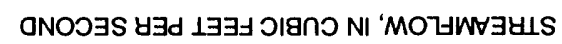
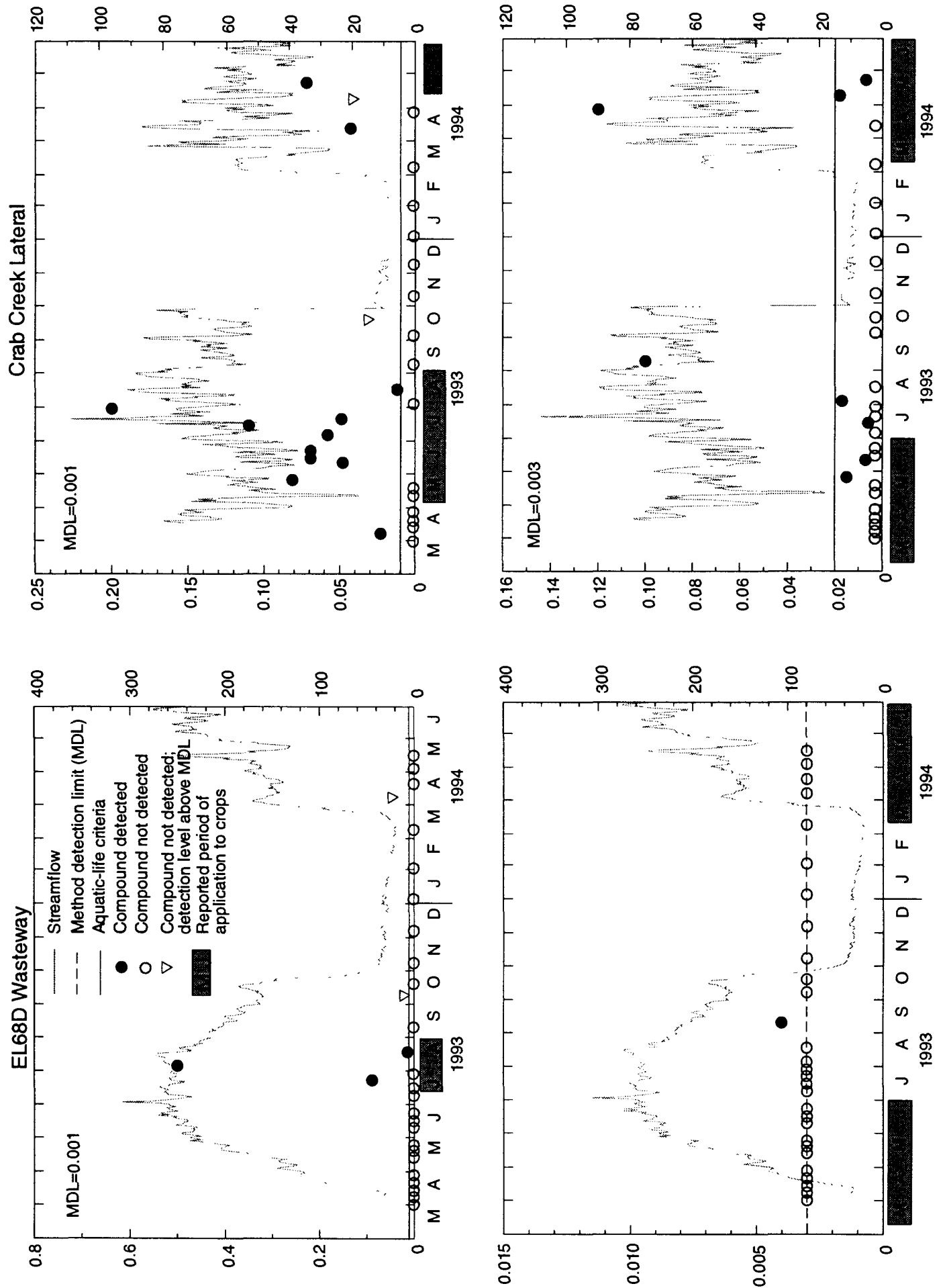

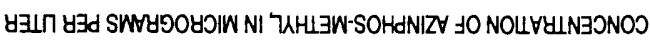

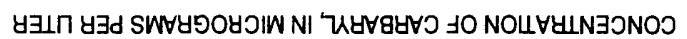

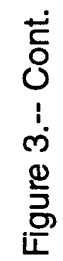



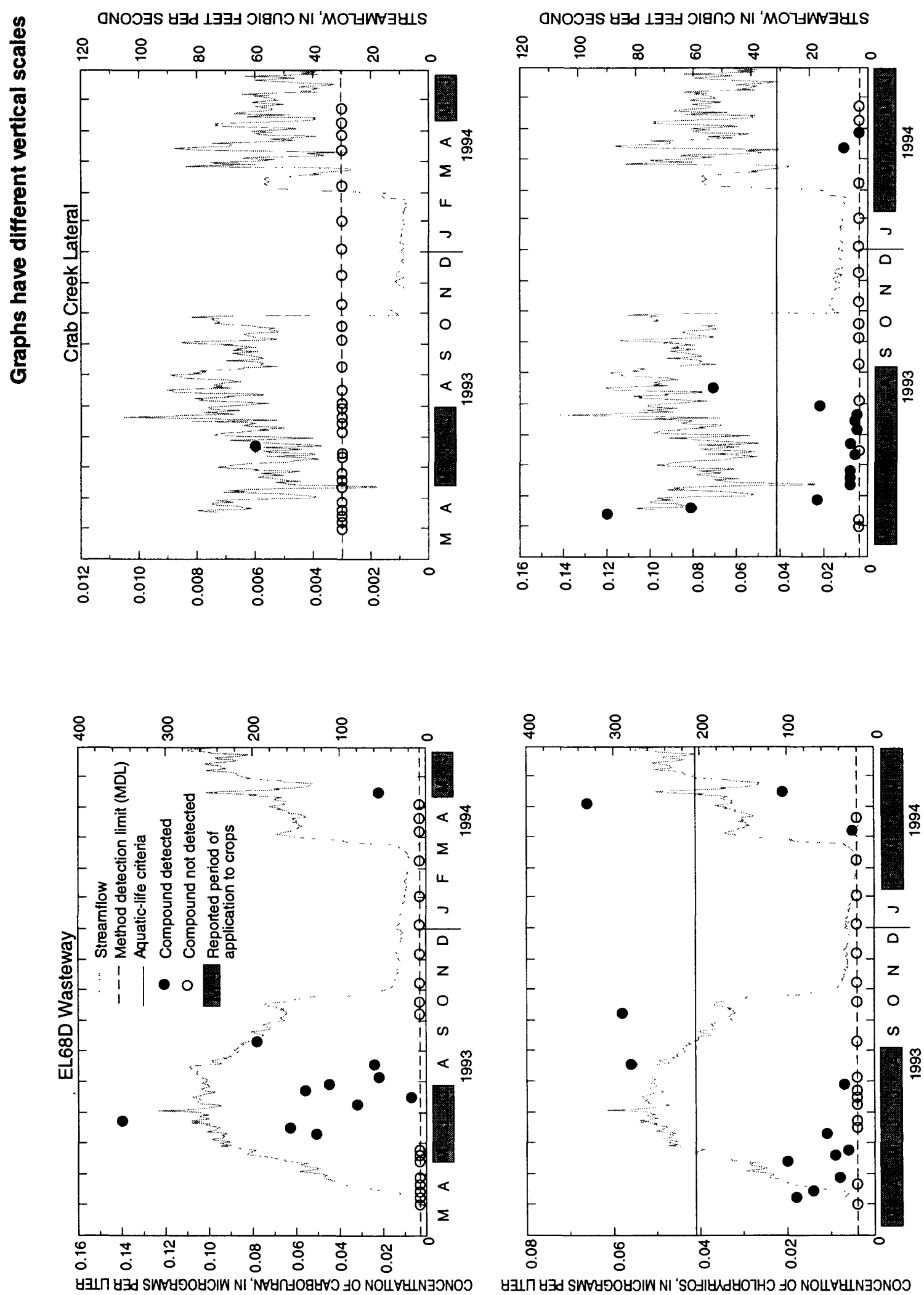

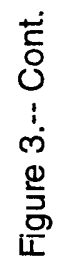




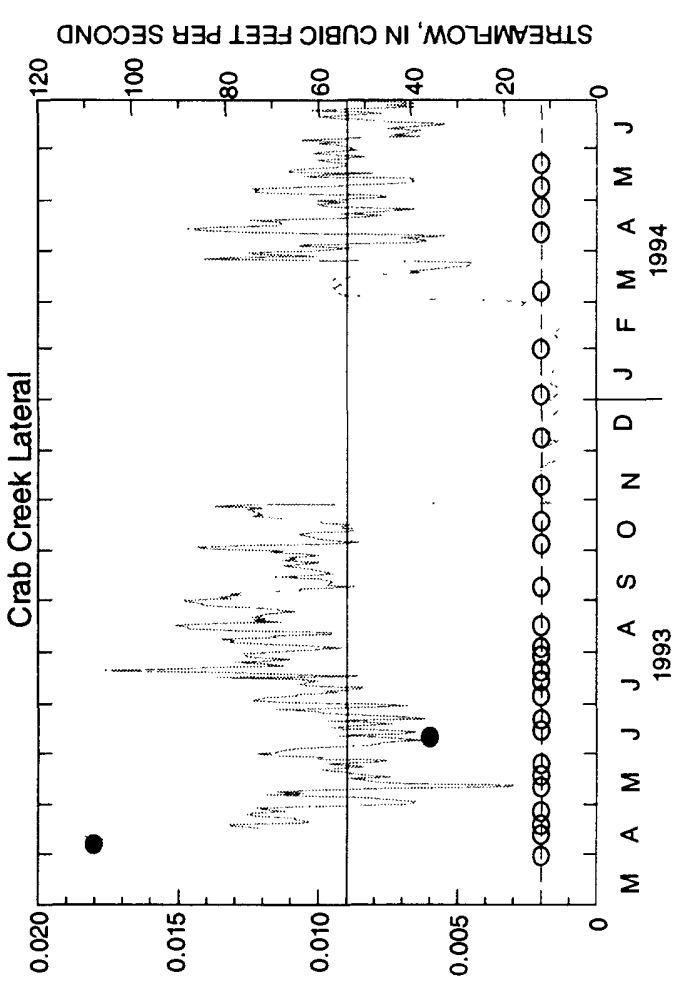

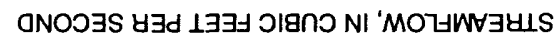
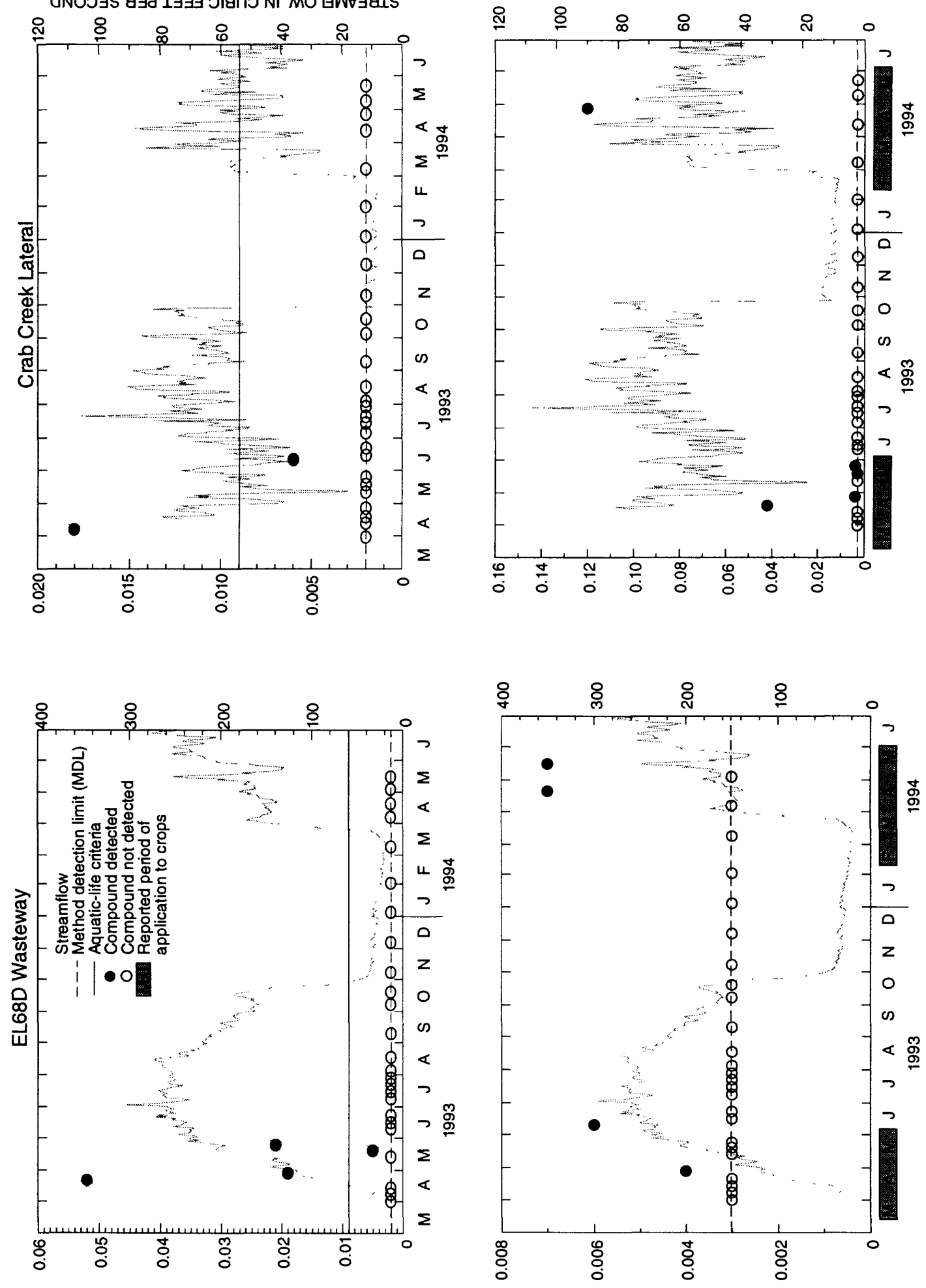

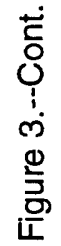



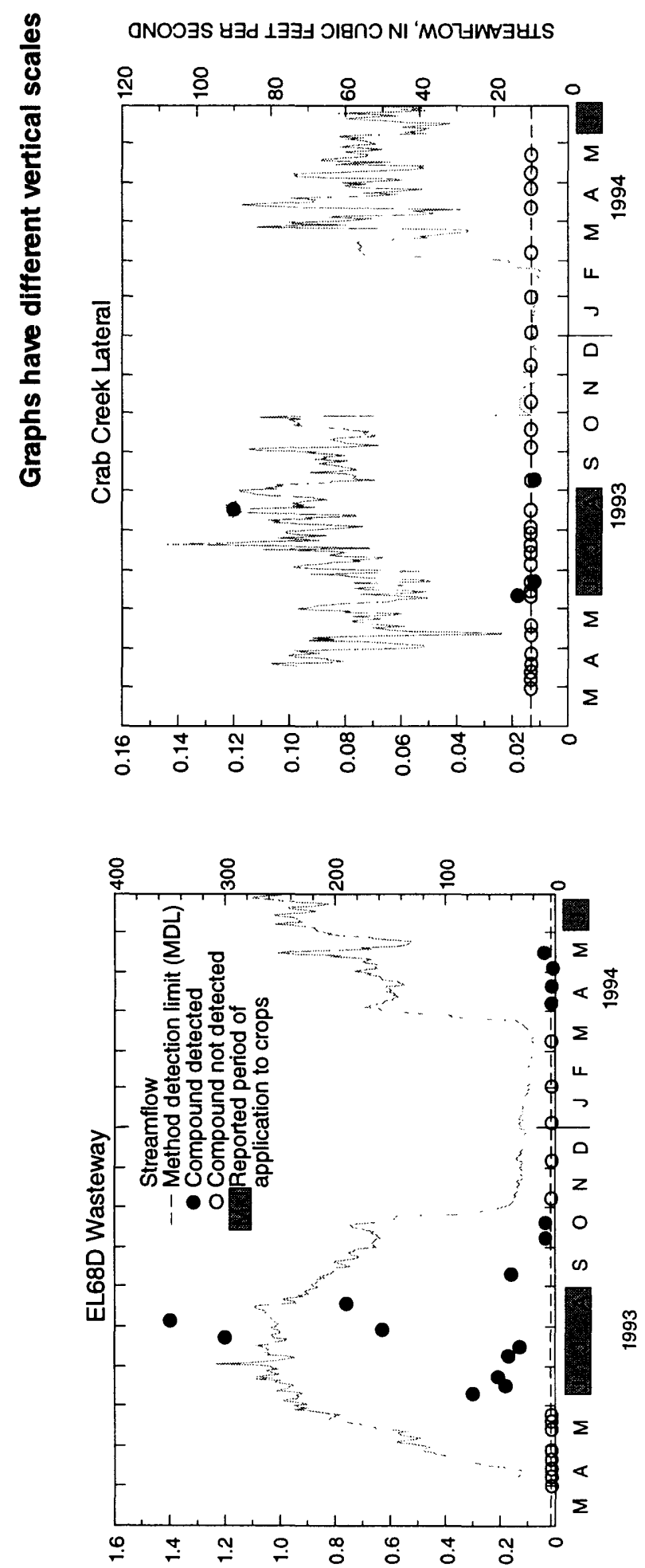

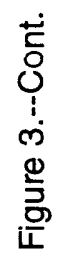




\section{Dryland Agricultural Drainage Basins}

Herbicides are the predominant types of pesticides applied to cropland in the two dryland agricultural drainage basins; and the herbicides glyphosate and triallate account for more than one-third of the herbicide use in the Upper Crab Creek and Palouse River drainage basins, respectively (table 5). The herbicides diuron and 2,4-D also account for nearly one-third of the herbicide use in each of the respective drainage basins. There were 23 pesticides or pesticide metabolites detected in samples from the two sites in the dryland agricultural drainage basins (table 7). Atrazine, triallate, and simazine were the most frequently detected herbicides in samples collected from the two dryland drainage basin sites. Triallate is reported as the herbicide most frequently applied in the Palouse River drainage basin, whereas atrazine and simazine are not reported as applied to croplands in either of the dryland drainage basins. The herbicide prometon was detected frequently in samples from "ie Palouse River, although it is not reported as commonly applied to cropland in either of the dryland agricultural drainage basins. Several insecticides (Lindane, ethoprop, carbaryl and azinphos-methyl), although not reported as commonly applied to croplands in the dryland drainage basins, were detected in samples from the two sites. Lindane was the insecticide detected most frequently in the dryland agricultural drainage basins. The large drainage area and multiple land use of the Palouse River drainage basin may explain the larger variety of pesticides detected in samples at the Palouse River site in comparison to the Upper Crab Creek site. Concentrations of pesticides found in the dryland agricultural drainage basins did not exceed the USEPA drinking water standards, but concentrations of two insecticides and one herbicide did exceed the aquaticlife criteria. The only detection of the insecticide diazinon in one sample from the Palouse River, the only detection of the insecticide azinphos-methyl in one sample from Upper Crab Creek, and the detections of the herbicide triallate in three samples from the Palouse River exceeded the aquatic-life criteria. The relation of concentrations of pesticides, corresponding streamflows, and reported periods of application are shown graphically (fig. 4) for the nine compounds that were detected five or more times or exceeded aquatic-life criteria at either of the two surface-water sites located in the dryland agricultural drainage basins.

\section{Comparison of Irrigated and Dryland Agricultural Areas}

A wider variety of pesticides is used on croplands in the irrigated agricultural areas than in the dryland agricultural areas (table 5), and more types of pesticides were detected in surface water from the irrigated drainage basins (table 4). Herbicides like EPTC, terbacil, and alachlor are used in large amounts and are commonly detected in the irrigated drainage basins, but are not commonly used or detected in the dryland drainage basins. Conversely, triallate and MCPA are herbicides used in large amounts and commonly detected in the dryland areas, but not in the irrigated areas. Propargite and chlorpyrifos, insecticides that are used in large amounts and frequently detected in the irrigated drainage basins, are not commonly used or detected in the dryland drainage basins. Lindane and prometon were not reported as applied to croplands but were detected commonly in the Palouse River drainage basin.

Atrazine is a pesticide commonly detected in both the irrigated and dryland drainage basins (table 4). Applications of atrazine to irrigated cropland make up about 3 percent of the total herbicide applications, but less than 1 percent of the total herbicide applications to dryland crops (table 5). Simazine, another herbicide commonly detected at all sites, constituted no more than 2 percent of the total amount of herbicides applied to cropland in any of the drainage basins. Detections of these and other compounds may relate to nonagricultural uses not included in table 5, such as road and railway right-of-way applications, industrial, or domestic use. 
Table 7.--Summary of pesticide concentrations from two surface-water sites located in dryland agricultural drainage basins in the Central Columbia Plateau, Washington and Idaho

[H, herbicide; I, insecticide; $\mathrm{M}$, metabolite; $\mu \mathrm{g} / \mathrm{L}$, micrograms per liter; $<$, less than. Pesticide concentrations in bold represent values that exceed the freshwater-chronic criteria for protection of aquatic life (see table 3)]

\begin{tabular}{|c|c|c|c|c|c|c|}
\hline \multirow[b]{2}{*}{$\begin{array}{l}\text { Compound } \\
\text { name }\end{array}$} & \multirow[b]{2}{*}{$\begin{array}{l}\text { Type of } \\
\text { pesticide }\end{array}$} & \multirow{2}{*}{$\begin{array}{l}\text { Method } \\
\text { detec- } \\
\text { tion } \\
\text { limit } \\
(\mu \mathrm{g} / \mathrm{L})\end{array}$} & \multicolumn{2}{|c|}{ Concentrations } & \multirow{2}{*}{$\begin{array}{l}\text { Number } \\
\text { of } \\
\text { detec- } \\
\text { tions }\end{array}$} & \multirow{2}{*}{$\begin{array}{l}\text { Number } \\
\text { of detect- } \\
\text { tions that } \\
\text { exceed } \\
\text { aquatic-life } \\
\text { criteria }\end{array}$} \\
\hline & & & $\begin{array}{l}\text { Median } \\
(\mu \mathrm{g} / \mathrm{L})\end{array}$ & $\begin{array}{l}\text { Maximum } \\
(\mu \mathrm{g} / \mathrm{L})\end{array}$ & & \\
\hline
\end{tabular}

Palouse River (27 samples)

\begin{tabular}{|c|c|c|c|c|c|}
\hline Atrazine & $\mathrm{H}$ & ${ }^{1} 0.009$ & 0.02 & 0.2 & 23 \\
\hline Triallate & $\mathrm{H}$ & 0.001 & 0.018 & 0.49 & 24 \\
\hline Simazine & $\mathrm{H}$ & 0.005 & 0.015 & 0.069 & 21 \\
\hline Prometon & $\mathrm{H}$ & 0.018 & 0.007 & 0.058 & 17 \\
\hline DCPA (Dacthal) & $\mathrm{H}$ & 0.002 & $<0.002$ & 0.006 & 12 \\
\hline gamma-HCH & I & 0.004 & $<0.004$ & 0.036 & 9 \\
\hline Metribuzin & $\mathrm{H}$ & 0.004 & $<0.004$ & 0.052 & 9 \\
\hline EPTC & $\mathrm{H}$ & 0.002 & $<0.002$ & 0.012 & 7 \\
\hline MCPA & $\mathrm{H}$ & 0.05 & $<0.05$ & 0.24 & 5 \\
\hline Tebuthiuron & $\mathrm{H}$ & 0.01 & $<0.01$ & 0.01 & 4 \\
\hline 2,4-D & $\mathrm{H}$ & 0.035 & $<0.035$ & 0.15 & 3 \\
\hline Metolachlor & $\mathrm{H}$ & 0.002 & $<0.002$ & 0.004 & 3 \\
\hline Alachlor & $\mathrm{H}$ & 0.002 & $<0.002$ & 0.006 & 2 \\
\hline Bromoxynil & $\mathrm{H}$ & 0.035 & $<0.035$ & 0.6 & 2 \\
\hline Diuron & $\mathrm{H}$ & 0.02 & $<0.02$ & 0.47 & 2 \\
\hline Ethoprop & I & 0.003 & $<0.003$ & 0.005 & 2 \\
\hline Desethyl atrazine ${ }^{2}$ & $\mathbf{M}$ & 0.002 & $<0.002$ & $\mathrm{E}_{0.001}$ & 1 \\
\hline Diazinon & I & 0.002 & $<0.002$ & 0.012 & 1 \\
\hline Ethalfluralin & $\mathrm{H}$ & 0.004 & $<0.004$ & 0.013 & 1 \\
\hline alpha-HCH & $\mathbf{M}$ & 0.002 & $<0.002$ & 0.007 & 1 \\
\hline Trifluralin & $\mathrm{H}$ & 0.002 & $<0.002$ & 0.007 & 1 \\
\hline
\end{tabular}

Upper Crab Creek (19 samples)

\begin{tabular}{|c|c|c|c|c|c|}
\hline Atrazine & $\mathrm{H}$ & ${ }^{1} 0.009$ & $<0.009$ & 0.03 & 2 \\
\hline Simazine & $\mathrm{H}$ & 0.005 & $<0.005$ & 0.042 & 6 \\
\hline Triallate & $\mathrm{H}$ & 0.001 & $<0.001$ & 0.65 & 6 \\
\hline 2,4-D & $\mathrm{H}$ & 0.035 & $<0.035$ & 0.24 & 2 \\
\hline Carbaryl $^{2}$ & I & 0.003 & $<0.003$ & $\mathrm{E}_{0.02}$ & 2 \\
\hline Alachlor & $\mathrm{H}$ & 0.002 & $<0.002$ & 0.01 & 1 \\
\hline Azinphos-methyl $^{2}$ & I & 0.001 & $<0.001$ & $\mathbf{E}_{0.04}$ & 1 \\
\hline DCPA & $\mathrm{H}$ & 0.002 & $<0.002$ & 0.002 & 1 \\
\hline
\end{tabular}


Table 7.--Summary of pesticide concentrations from two surface-water sites located in dryland agricultural drainage basins in the Central Columbia Plateau, Washington and Idaho--Continued

\begin{tabular}{|c|c|c|c|c|c|c|}
\hline \multirow[b]{2}{*}{$\begin{array}{l}\text { Compound } \\
\text { name }\end{array}$} & \multirow[b]{2}{*}{$\begin{array}{l}\text { Type of } \\
\text { pesticide }\end{array}$} & \multirow{2}{*}{$\begin{array}{l}\text { Method } \\
\text { detec- } \\
\text { tion } \\
\text { limit } \\
(\mu \mathrm{g} / \mathrm{L})\end{array}$} & \multicolumn{2}{|c|}{ Concentrations } & \multirow{2}{*}{$\begin{array}{l}\text { Number } \\
\text { of } \\
\text { detec- } \\
\text { tions }\end{array}$} & \multirow{2}{*}{$\begin{array}{l}\text { Number } \\
\text { of detect- } \\
\text { tions that } \\
\text { exceed } \\
\text { aquatic-life } \\
\text { criteria }\end{array}$} \\
\hline & & & $\begin{array}{l}\text { Median } \\
(\mu \mathrm{g} / \mathrm{L})\end{array}$ & $\begin{array}{l}\text { Maximum } \\
(\mu \mathrm{g} / \mathrm{L})\end{array}$ & & \\
\hline
\end{tabular}

\section{Upper Crab Creek (19 samples)--Continued}

$\begin{array}{lllllll}\text { Diuron } & \mathrm{H} & 0.02 & <0.02 & 0.07 & 1 & 0 \\ \text { EPTC } & \mathrm{H} & 0.002 & <0.002 & 0.008 & 1 & 0 \\ \text { Prometon } & \mathrm{H} & 0.018 & <0.018 & 0.01 & 1 & 0\end{array}$

\footnotetext{
${ }^{1}$ Estimated reporting level due to bias in concentrations of atrazine in field and equipment blanks (see section titled Results of Quality-Control Samples).

${ }^{2}$ Concentrations for these pesticides are qualitatively identified and reported with an E code (estimated value) because of problems with gas chromatography or extraction (Zaugg and others, 1995).

E Concentration is an estimated value because of problems with gas chromatography or extraction (Zaugg and others, 1995).
} 

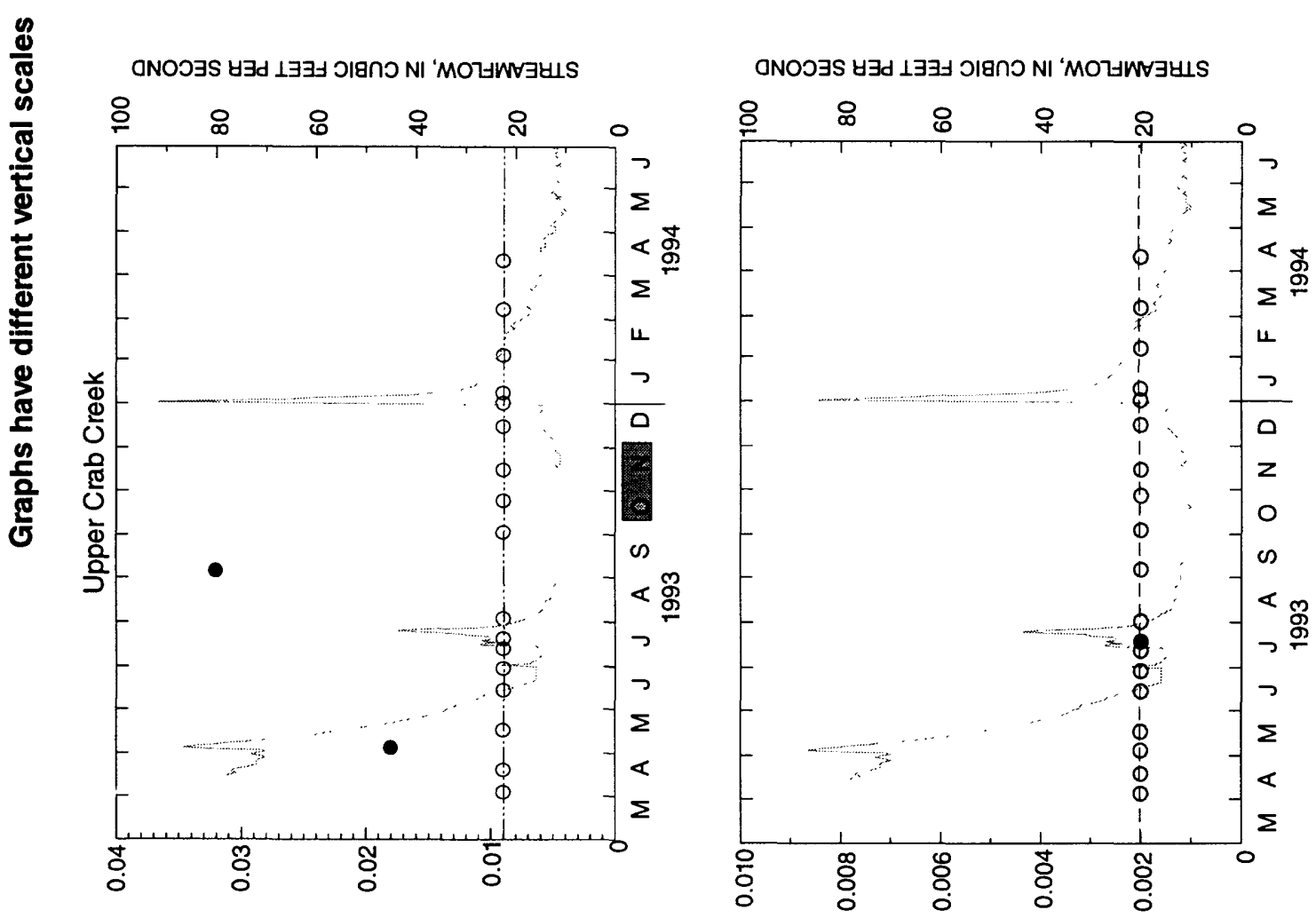

ํํㅇํㅇํㅇ

余

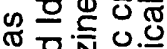

ฮั

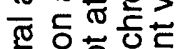

곡웅워웡

.

宁祭步

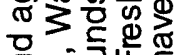

帘

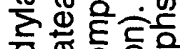

음 $\frac{\pi}{2}$ 응은

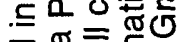

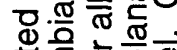

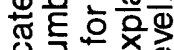

응드의

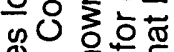

क留

屯 ญ ญ

To

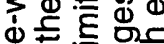

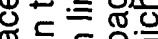

is $0 .-\frac{1}{3}$

क.

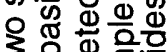

过宁

ซ웜

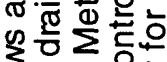

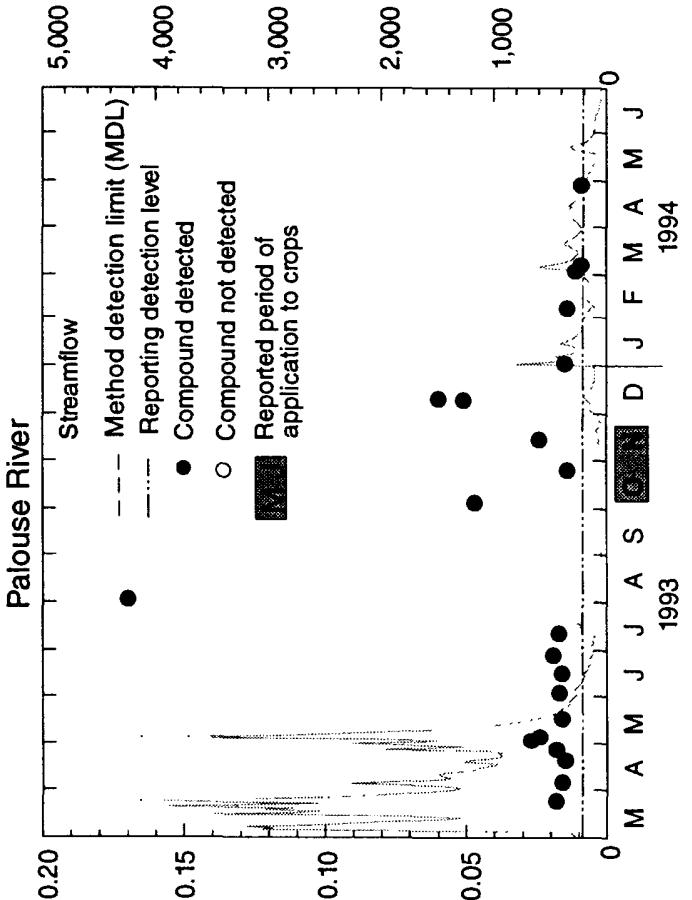

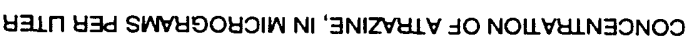

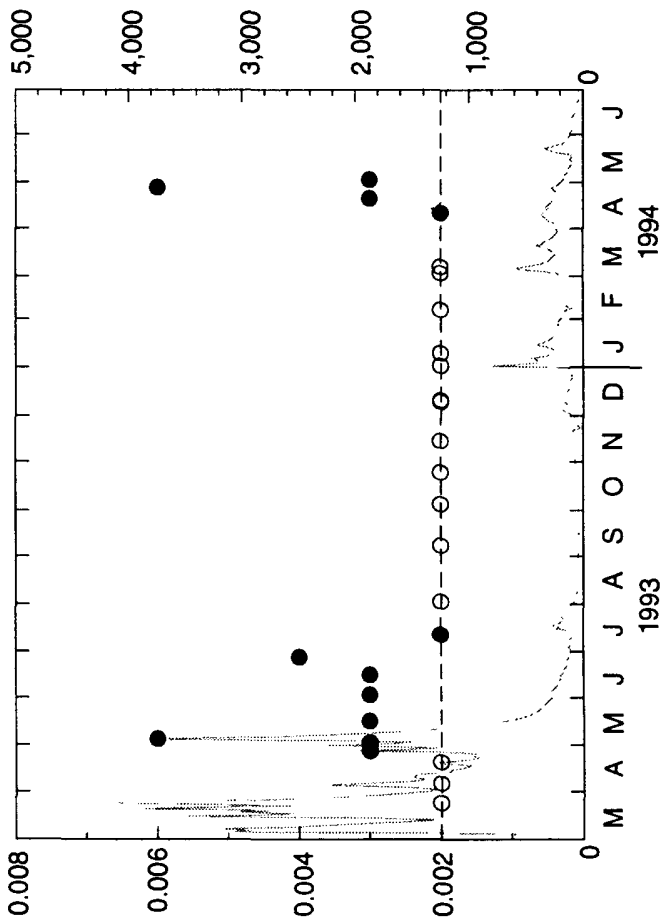

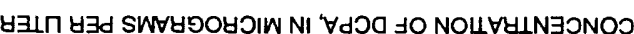

응ㅇㅇㅇㅡ

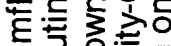

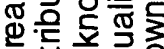

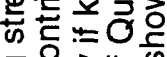

ర్ర

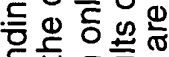

응.동

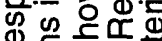

통은

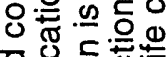

으응ㄷㅇ은

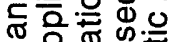

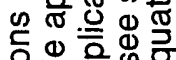

음응요

은

도원은

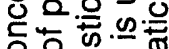

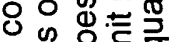

응 능 흐

는 응 응

흥으을

\$잉워

농 응응 ナ 웡

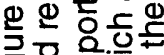

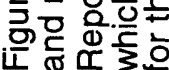



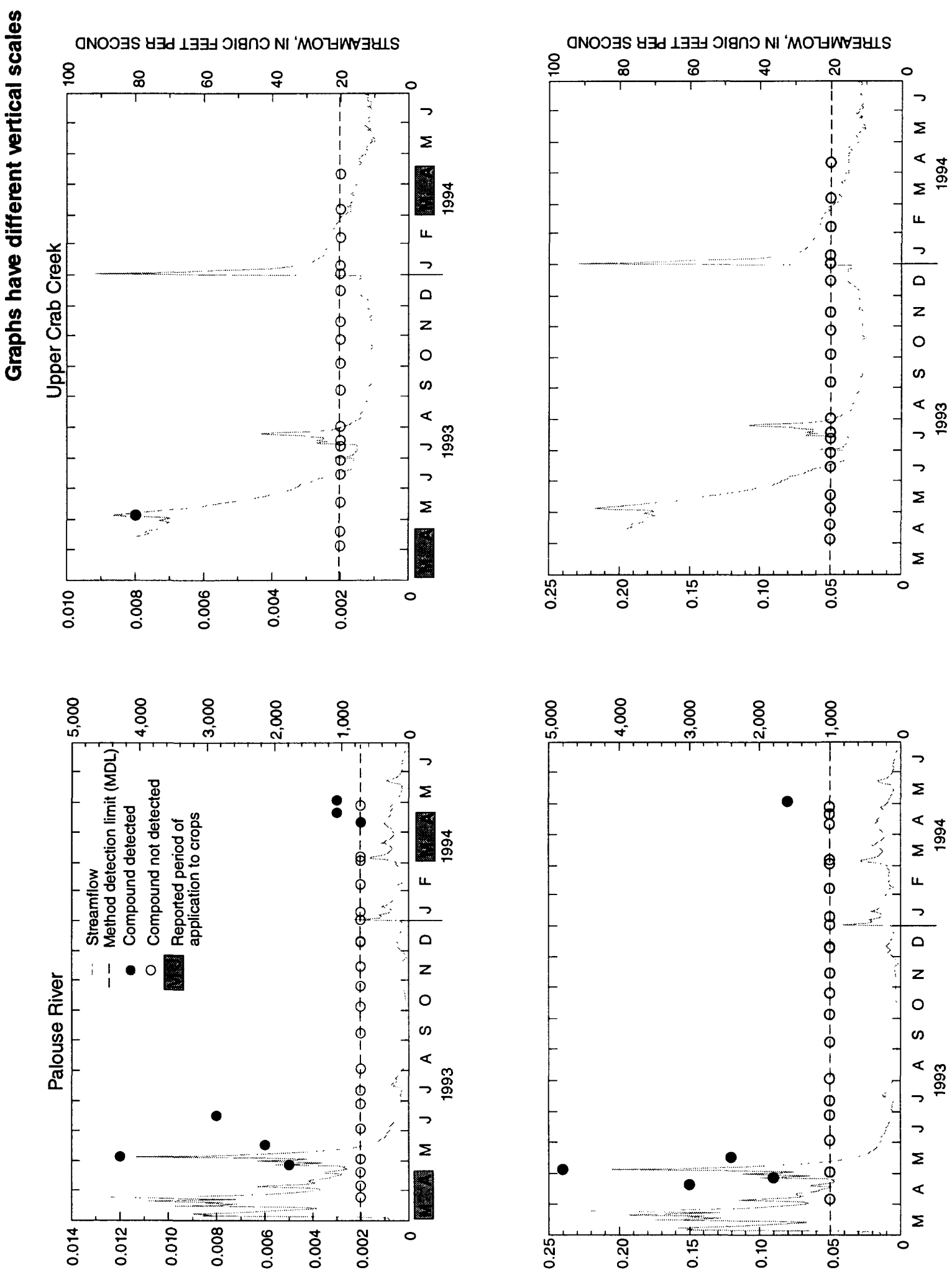

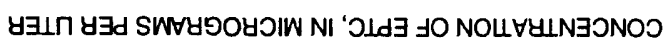

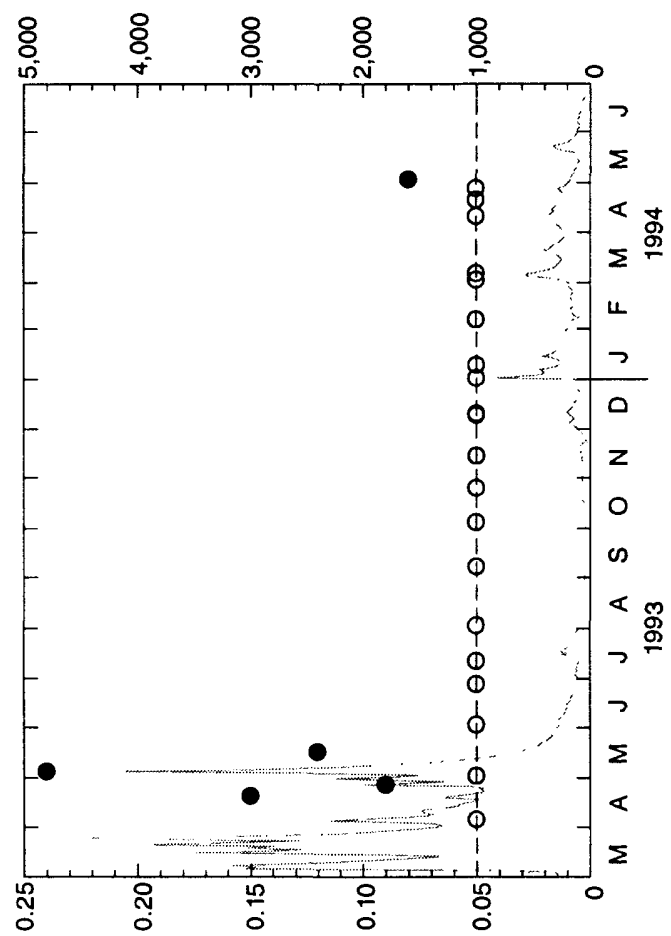

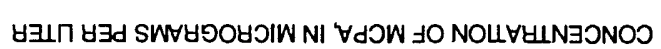



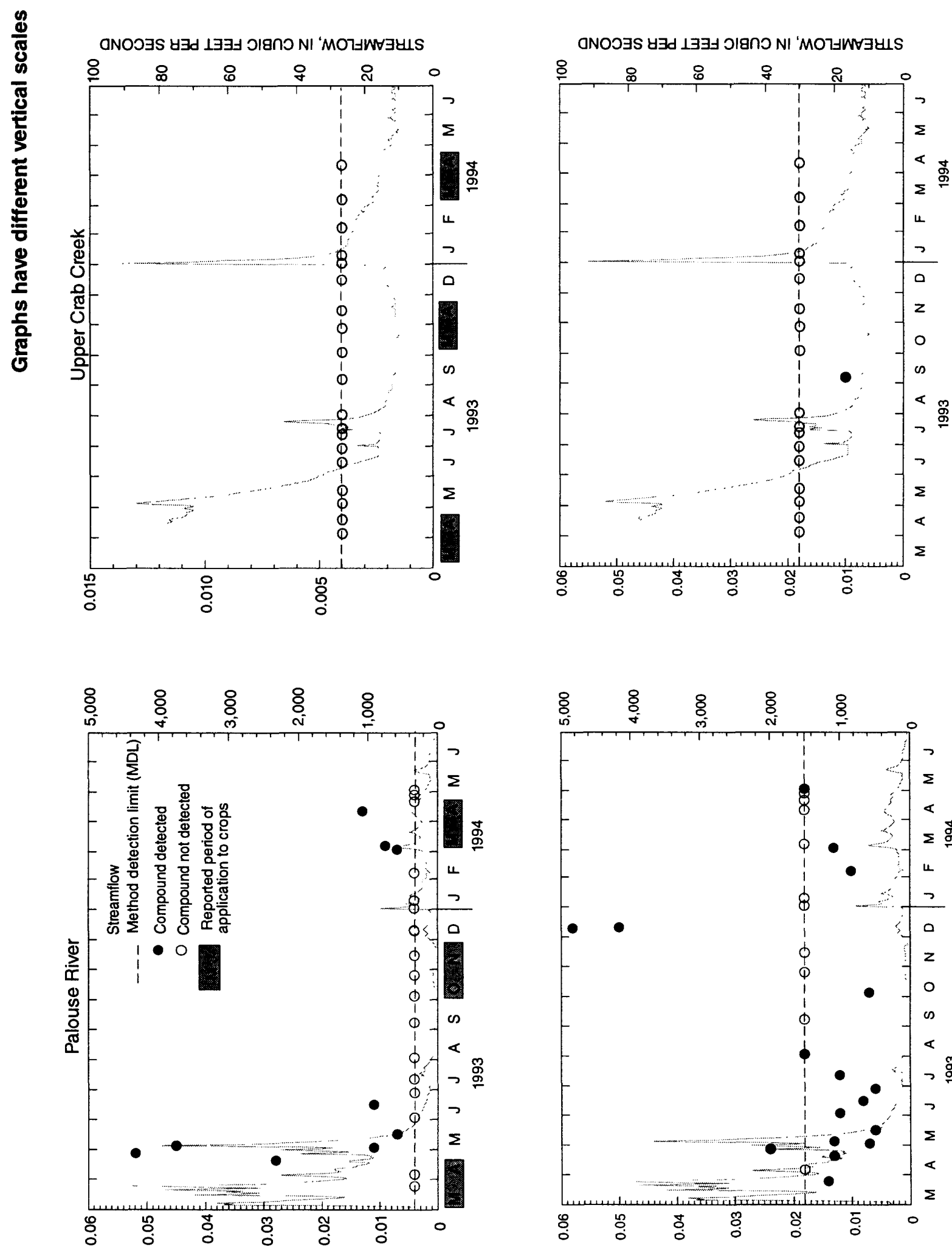

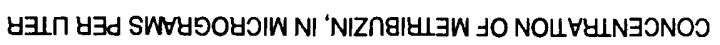

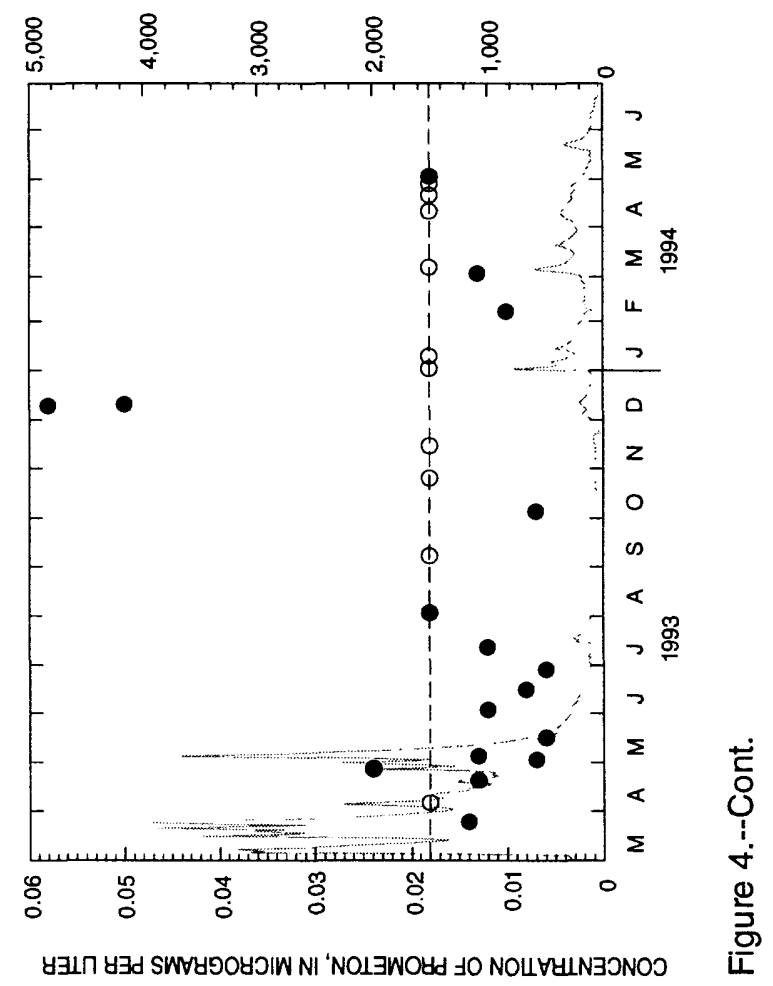



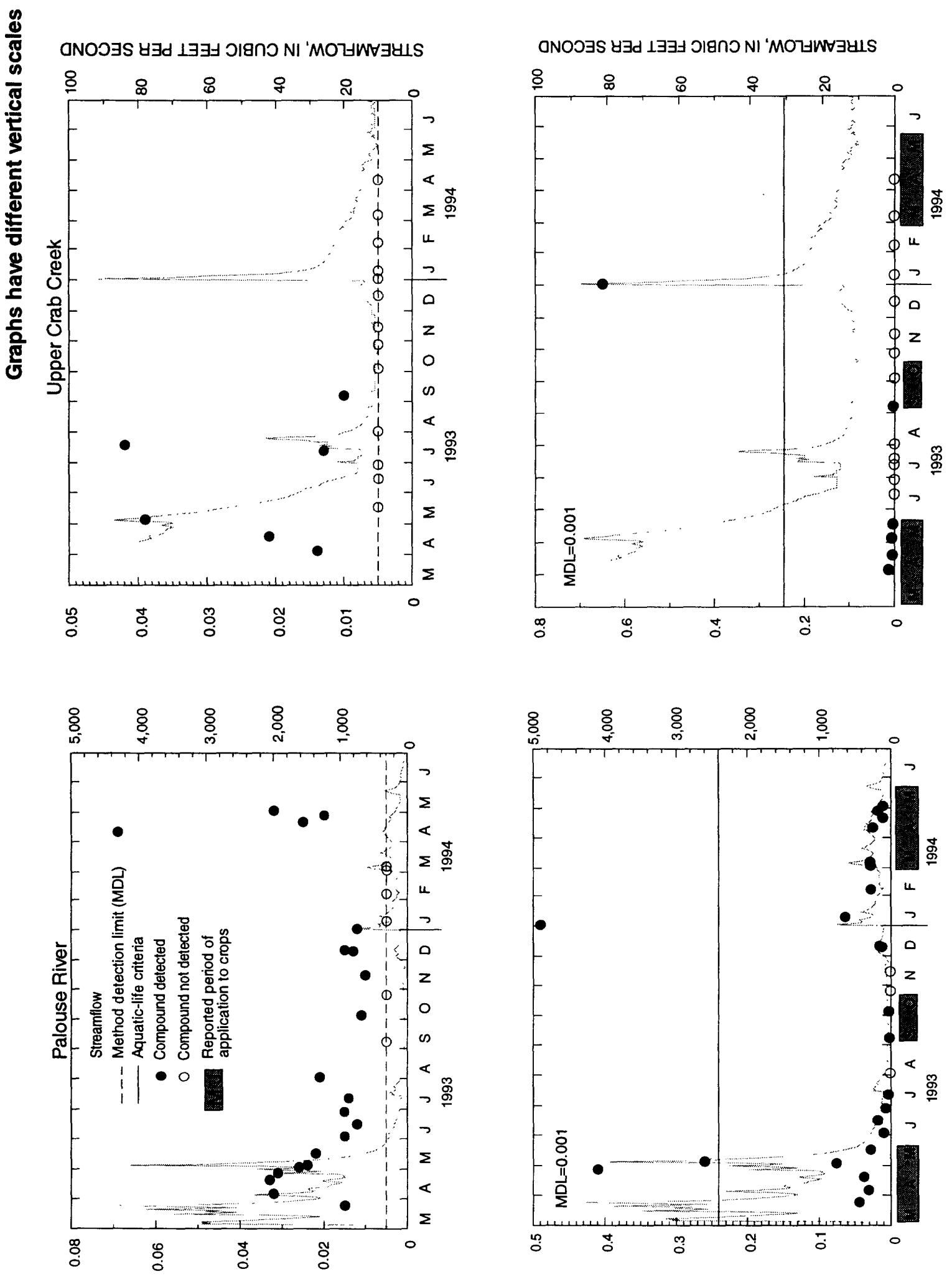

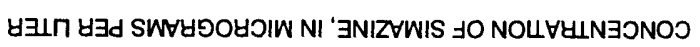

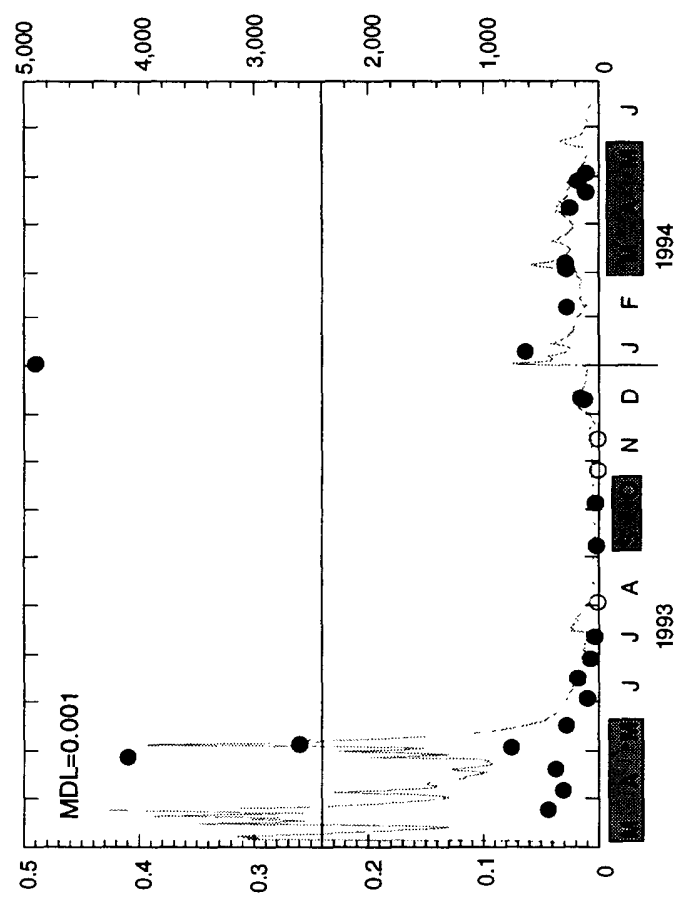

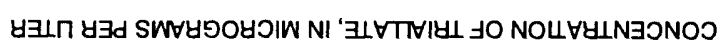

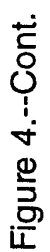



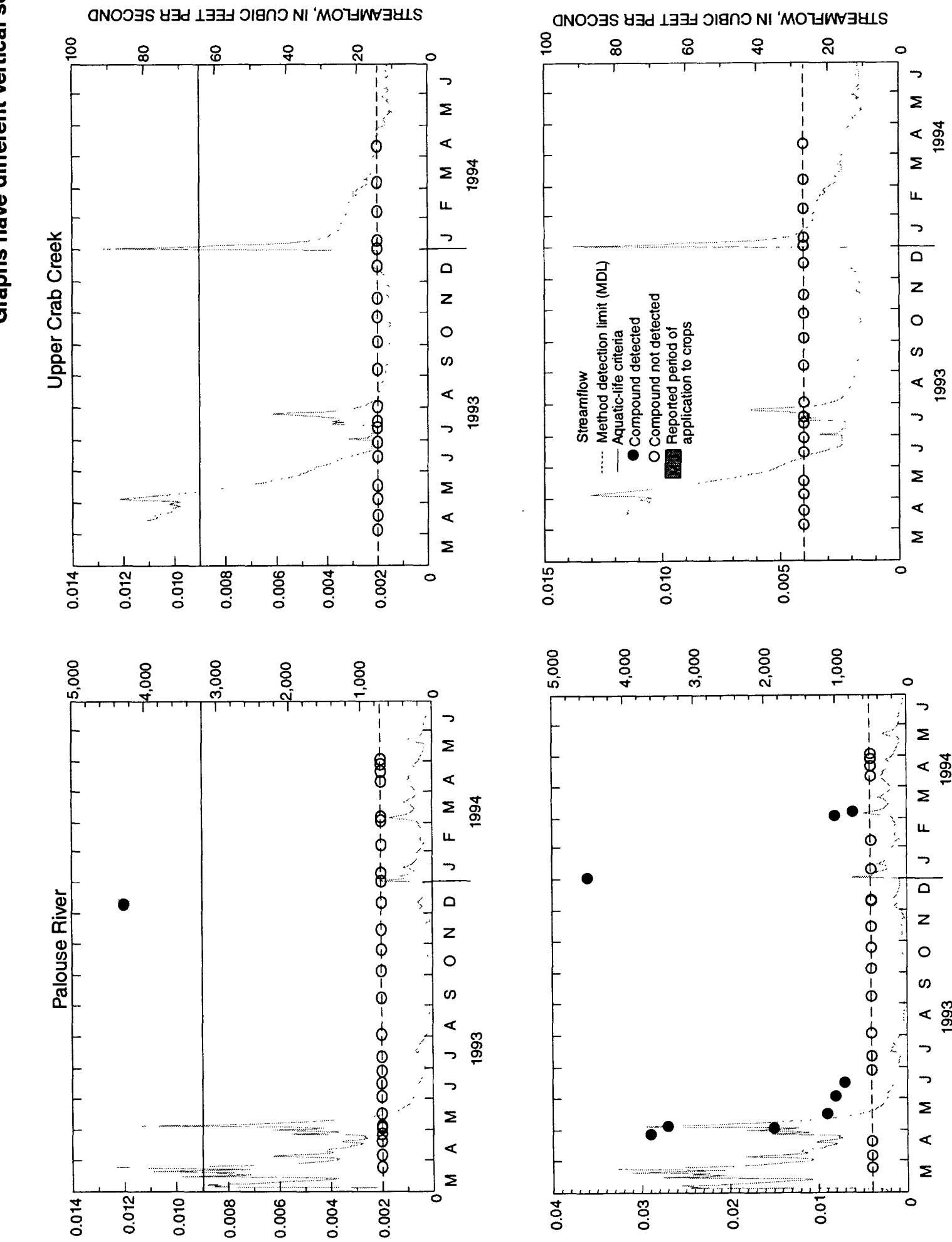

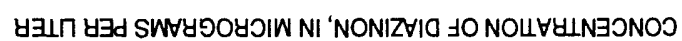

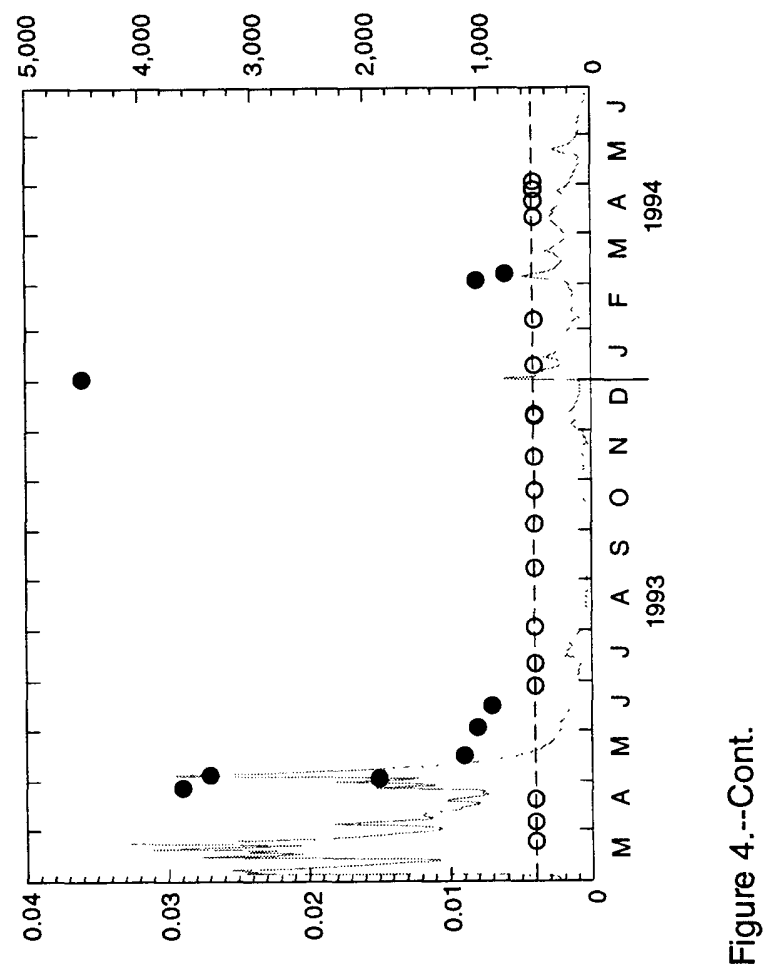

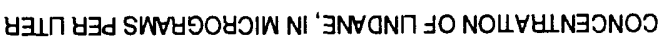




\section{SELECTED REFERENCES}

Anderson, J.E., and Gianessi, L.P., 1995, Pesticide use in the central Columbia Plateau: Washington, D.C., National Center for Food and Agricultural Policy, misc. pagination.

Boucher, P.R., 1970, Sediment transport by streams in the Palouse River basin, Washington and Idaho: U.S. Geological Survey Water-Supply Paper 1899-C, $37 \mathrm{p}$.

Canadian Council of Ministers of the Environment, 1993, Canadian water quality guidelines: Ottawa, Ontario, Environmental Quality Guidelines Division, Inland Waters Directorate, misc. pagination.

Davis, D.A., 1993, Washington State pesticide monitoring program--reconnaissance sampling of surface waters (1992): Olympia, Washington, Washington State Department of Ecology, $38 \mathrm{p}$.

Edwards, T.K., and Glysson, G.D., 1988, Field methods for measurement of fluvial sediment: U.S. Geological Survey Open-File Report 86-531, 118 p.

Gianessi, L.P., and Puffer, C.A., 1991, Herbicide use in the United States: Washington, D.C., Resources for the Future, Inc., Quality of the Environment Division, $128 \mathrm{p}$.

1992a, Insecticide use in U.S. crop production:

Washington, D.C., Resources for the Future, Inc., Quality of the Environment Division, misc. pagination.

1992b, Fungicide use in U.S. crop production: Washington, D.C., Resources for the Future, Inc., Quality of the Environment Division, misc. pagination.

Gilliom, R.J., Alley, W.M., and Gurtz, M.E., 1995, Design of the National Water-Quality Assessment Program--occurrence and distribution of waterquality conditions: U.S. Geological Survey Circular 1112, $33 \mathrm{p}$.
Greene, K.E., Ebbert, J.C., and Munn, M.D., 1994, Nutrients, suspended sediment, and pesticides in streams and irrigation systems in the Central Columbia Plateau in Washington and Idaho, 1959-1991: U.S. Geological Survey Open-File Report 94-4215, approx. $100 \mathrm{p}$.

Hirsch, R.M., Alley, W.A., and Wilber, W.G., 1988, Concepts for a National Water-Quality Assessment Program: U.S. Geological Survey Circular 1021, $42 \mathrm{p}$.

Leahy, P.P., Rosenshein, J.S., and Knopman, D.S., 1990, Implementation plan for the National Water-Quality Assessment Program: U.S. Geological Survey Open-File Report 90-174, 10 p.

Majewski, M.S., and Capel, P.D., 1995, Pesticides in the atmosphere--distribution, trends, and governing factors: Ann Arbor, Mich., Ann Arbor Press, Inc., $189 \mathrm{p}$.

Nowell, L.H., and Resek, E.A., 1994, Summary of national standards and guidelines for pesticides in water, bed sediment, and aquatic organisms and their application to water-quality assessments: U.S. Geological Survey Open-File Report 94-44, 115 p.

Pritt, J.W., and Raese, J.W., 1992, Quality assurance/ quality control manual, National Water Quality Laboratory: U.S. Geological Survey Open-File Report 92-0495, 33 p.

Sandstrom, M.W., Wydoski, D.S., Schroeder, M.P., Zamboni, J.L., and Foreman, W.T., 1992, Methods of analysis by the National Water Quality Laboratory--determination of organonitrogen herbicides in water by solid-phase extraction and capillary-column gas chromatography/mass spectrometry with selected-ion monitoring: U.S. Geological Survey Open-File Report 91-519, 26 p.

Shelton, L.R., 1994, Field guide for collecting and processing stream-water samples for the National Water-Quality Assessment Program: U.S. Geolngical Survey Open-File Report 94-455, 42 p. 
Squillace, P.J., and Thurman, E.M., 1992, Herbicide transport in rivers--importance of hydrology and geochemistry in nonpoint-source contamination: Environmental Science \& Technology, v. 26, no. 3, p. $538-545$.

U.S. Department of Commerce, 1994, 1992 census of agriculture, Washington State and county data: U.S. Department of Commerce AC92-A-47, v. 1, part 47, $332 \mathrm{p}$.

U.S. Geological Survey, 1986, Land use and land cover digital data from 1:250,000- and 1:100,000-scale maps: Data Users Guide 4, 33 p.

Van Metre, P., and Seevers, P., 1991, Use of Landsat imagery to estimate ground-water pumpage for irrigation on the Columbia Plateau in eastern Washington, 1985: U.S. Geological Survey Open-File Report 89-4157, 38 p.

Washington State Department of Social and Health Services, 1975 [1974], Pesticide residues in the Columbia Basin Irrigation Project, January 1 through December 31, 1974: Olympia, Washington, State of Washington Health Services Division, contract no. 14-06-100-8050, January 28, 1975 [1974], unpaginated.
1976, Pesticide monitoring program, 1975 annual report, U.S. Bureau of Reclamation, Columbia Basin Project: Olympia, Washington, State of Washington Health Services Division, January 1976, 27 p.

1977, Pesticide monitoring program, 1976 annual report, U.S. Bureau of Reclamation Columbia Basin Project: Olympia, Washington, State of Washington Health Services Division, February 1977, 28 p.

1978, Pesticide monitoring program, 1977 annual report, U.S. Bureau of Reclamation Columbia Basin Project: Olympia, Washington, State of Washington Health Services Division, March 1978, 16 p.

1979, Pesticide monitoring program, 1978 annual report, U.S. Bureau of Reclamation Columbia Basin Project: Olympia, Washington, State of Washington Health Services Division, 13 p.

Zaugg, S.D., Sandstrom, M.W., Smith, S.G., and Fehlberg, K.M., 1995, Methods of analysis by the U.S. Geological Survey National Water Quality Laboratory--determination of pesticides in water by C-18 solid-phase extraction and capillary-column gas chromatography/mass spectrometry with selected-ion monitoring: U.S. Geological Survey Open-File Report 95-181, 49 p. 
Appendix A1.--Concentrations and precision data for replicate samples with pesticide detections $[\mu \mathrm{g} / \mathrm{L}$, micrograms per liter; $<$, less than; --, no data]

\begin{tabular}{|c|c|c|c|c|c|}
\hline $\begin{array}{l}\text { Pesticide } \\
\text { target analyte }\end{array}$ & $\begin{array}{l}\text { Concen- } \\
\text { tration in } \\
\text { replicates } \\
(\mu \mathrm{g} / \mathrm{L})\end{array}$ & $\begin{array}{l}\text { Relative } \\
\text { standard } \\
\text { deviation }{ }^{1} \\
\text { (percent) }\end{array}$ & $\begin{array}{l}\text { Pesticide } \\
\text { target analyte }\end{array}$ & $\begin{array}{l}\text { Concen- } \\
\text { tration in } \\
\text { replicates } \\
(\mu \mathrm{g} / \mathrm{L})\end{array}$ & $\begin{array}{l}\text { Relative } \\
\text { standard } \\
\text { deviation } \\
\text { (percent) }\end{array}$ \\
\hline $2,4-\mathrm{D}$ & $\begin{array}{c}0.24 \\
<0.035\end{array}$ & -- & EPTC (Eptam) & $\begin{array}{l}0.02 \\
0.02\end{array}$ & 0.0 \\
\hline Alachlor & $\begin{array}{l}0.012 \\
0.011\end{array}$ & 8.7 & & $\begin{array}{l}0.005 \\
0.006 \\
0.005\end{array}$ & 10.8 \\
\hline \multirow[t]{5}{*}{ Atrazine } & $\begin{array}{l}0.006 \\
0.005\end{array}$ & 18.2 & & $\begin{array}{l}0.004 \\
0.004\end{array}$ & 0.0 \\
\hline & $\begin{array}{l}0.053 \\
0.055\end{array}$ & 1.9 & Ethoprop & $\begin{array}{l}0.042 \\
0.043\end{array}$ & 2.4 \\
\hline & $\begin{array}{l}0.012 \\
0.012 \\
0.01\end{array}$ & 10.2 & Metolachlor & $\begin{array}{l}0.009 \\
0.01\end{array}$ & 10.5 \\
\hline & $\begin{array}{l}0.013 \\
0.013\end{array}$ & 0.0 & & $\begin{array}{l}0.007 \\
0.007\end{array}$ & 0.0 \\
\hline & $\begin{array}{l}0.047 \\
0.047\end{array}$ & 0.0 & Prometon & $\begin{array}{l}0.007 \\
0.01\end{array}$ & 35.3 \\
\hline Azinphos-methyl $^{2}$ & $\begin{array}{l}\mathrm{E}_{0.014} \\
\mathrm{E}_{0.019} \\
\mathrm{E}_{0.012}\end{array}$ & 24.0 & Propargite & $\begin{array}{l}0.95 \\
1.0 \\
0.96\end{array}$ & 2.7 \\
\hline Carbofuran $^{2}$ & $\begin{array}{l}\mathrm{E}_{0.024} \\
\mathrm{E}_{0.032} \\
\mathrm{E}_{0.021}\end{array}$ & 22.2 & Simazine & $\begin{array}{l}0.059 \\
0.057\end{array}$ & 3.4 \\
\hline \multirow[t]{2}{*}{ Chlorpyrifos } & $\begin{array}{l}0.081 \\
0.081\end{array}$ & 0.0 & & $\begin{array}{l}0.011 \\
0.011\end{array}$ & 0.0 \\
\hline & $\begin{array}{l}0.056 \\
0.063 \\
0.051\end{array}$ & 10.6 & Terbacil $^{2}$ & $\begin{array}{l}\mathrm{E}_{0.54} \\
\mathrm{E}_{0.54} \\
\mathrm{E}_{0.019} \\
\mathrm{E}_{0.024}\end{array}$ & 15.8 \\
\hline \multirow[t]{2}{*}{ DCPA } & $\begin{array}{l}0.3 \\
0.34\end{array}$ & 12.5 & & $\mathrm{E}_{0.018}$ & \\
\hline & $\begin{array}{l}0.018 \\
0.018 \\
0.017\end{array}$ & 3.3 & Triallate & $\begin{array}{l}0.003 \\
0.003 \\
0.004 \\
0.004\end{array}$ & 0.0 \\
\hline
\end{tabular}

\footnotetext{
${ }^{1}$ Precision is expressed as relative percent difference if only two samples are available.

${ }^{2}$ Concentrations for these pesticides are qualitatively identified and reported with an $\mathrm{E}$ code (estimated value) because of problems with gas chromatography or extraction (Zaugg and others, 1995).

${ }^{\mathrm{E}}$ Concentration is an estimated value because of problems with gas chromatography or extraction (Zaugg and others, 1995).
} 
Appendix A2.--Summary of recoveries from field-matrix- and laboratory-reagent-spike pesticide analyses

[SD, standard deviation of the mean recovery; --, no data; Laboratory-reagent spikes were analyzed at the National Water Quality Laboratory from December 1993 through March 1994]

\begin{tabular}{|c|c|c|c|c|c|c|}
\hline \multirow[b]{2}{*}{$\begin{array}{l}\text { Pesticide } \\
\text { target analyte }\end{array}$} & \multicolumn{3}{|c|}{ Field-matrix spikes } & \multicolumn{3}{|c|}{ Laboratory-reagent spikes } \\
\hline & $\begin{array}{l}\text { Mean } \\
\text { recovery } \\
\text { (percent) }\end{array}$ & $\begin{array}{l}\mathrm{SD} \\
\text { recovery } \\
\text { (percent) }\end{array}$ & $\begin{array}{l}\text { Number of } \\
\text { samples }\end{array}$ & $\begin{array}{l}\text { Mean } \\
\text { recovery } \\
\text { (percent) }\end{array}$ & $\begin{array}{l}\mathrm{SD} \\
\text { recovery } \\
\text { (percent) }\end{array}$ & $\begin{array}{l}\text { Number of } \\
\text { samples }\end{array}$ \\
\hline
\end{tabular}

$\underline{\text { Gas Chromatography/Mass Spectrometry analytical data }}$

\begin{tabular}{|c|c|c|c|c|c|}
\hline Alachlor & 104 & 19 & 7 & 122 & 16 \\
\hline Atrazine & 93 & 20 & 7 & 104 & 17 \\
\hline Azinphos-methyl ${ }^{1}$ & 134 & 90 & 7 & 86 & 30 \\
\hline Benfluralin & 62 & 6 & 7 & 94 & 12 \\
\hline Butylate & 83 & 7 & 7 & 107 & 12 \\
\hline Carbaryl $^{1,2}$ & 135 & 93 & 7 & 69 & 41 \\
\hline Carbofuran ${ }^{1,2}$ & 154 & 89 & 7 & 105 & 44 \\
\hline Chlorpyrifos & 97 & 17 & 7 & 107 & 17 \\
\hline Cyanazine & 113 & 25 & 7 & 116 & 22 \\
\hline DCPA & 108 & 14 & 7 & 110 & 17 \\
\hline$p, p^{\prime}-\mathrm{DDE}$ & 67 & 17 & 7 & 82 & 7 \\
\hline Desethyl atrazine ${ }^{1}$ & 29 & 9 & 7 & 30 & 6 \\
\hline Diazinon & 86 & 11 & 7 & 115 & 18 \\
\hline Dieldrin & 90 & 12 & 7 & 115 & 14 \\
\hline 2,6-Diethylanaline & 77 & 8 & 7 & 100 & 13 \\
\hline Dimethoate $e^{1,3,4}$ & -- & -- & 0 & 34 & 15 \\
\hline Disulfoton & 76 & 18 & 7 & 119 & 46 \\
\hline EPTC & 82 & 9 & 7 & 107 & 14 \\
\hline Ethalfluralin & 80 & 12 & 7 & 104 & 18 \\
\hline Ethoprop & 91 & 10 & 7 & 109 & 14 \\
\hline Fonofos & 87 & 18 & 7 & 99 & 16 \\
\hline alpha-HCH & 87 & 15 & 7 & 112 & 14 \\
\hline gamma-HCH & 84 & 23 & 7 & 110 & 13 \\
\hline Linuron $^{2}$ & 84 & 25 & 7 & 118 & 20 \\
\hline Malathion & 92 & 10 & 7 & 116 & 14 \\
\hline Methyl parathion & 90 & 32 & 7 & 112 & 22 \\
\hline Metolachlor & 108 & 19 & 7 & 133 & 19 \\
\hline Metribuzin & 73 & 10 & 7 & 86 & 17 \\
\hline Molinate & 83 & 10 & 7 & 112 & 13 \\
\hline Napropamide & 98 & 15 & 7 & 129 & 15 \\
\hline Parathion & 102 & 27 & 7 & 114 & 13 \\
\hline Pebulate & 81 & 8 & 7 & 106 & 13 \\
\hline Pendimethalin & 68 & 8 & 7 & 88 & 24 \\
\hline cis-Permethrin & 13 & 4 & 7 & 32 & 15 \\
\hline Phorate & 71 & 13 & 7 & 94 & 18 \\
\hline Prometon & 95 & 16 & 7 & 109 & 19 \\
\hline Pronamide & 85 & 15 & 7 & 100 & 22 \\
\hline Propachlor & 86 & 12 & 7 & 108 & 12 \\
\hline Propanil & 95 & 12 & 7 & 106 & 17 \\
\hline
\end{tabular}


Appendix A2.--Summary of mean recoveries from field-matrix-and laboratory-reagent-spike pesticide analyses-Continued

\begin{tabular}{|c|c|c|c|c|c|c|}
\hline \multirow[b]{2}{*}{$\begin{array}{l}\text { Pesticide } \\
\text { target analyte }\end{array}$} & \multicolumn{3}{|c|}{ Field-matrix spikes } & \multicolumn{3}{|c|}{ Laboratory-reagent spikes } \\
\hline & $\begin{array}{l}\text { Mean } \\
\text { recovery } \\
\text { (percent) }\end{array}$ & $\begin{array}{l}\mathrm{SD} \\
\text { recovery } \\
\text { (percent) }\end{array}$ & $\begin{array}{l}\text { Number of } \\
\text { samples }\end{array}$ & $\begin{array}{l}\text { Mean } \\
\text { recovery } \\
\text { (percent) }\end{array}$ & $\begin{array}{l}\mathrm{SD} \\
\text { recovery } \\
\text { (percent) }\end{array}$ & $\begin{array}{l}\text { Number of } \\
\text { samples }\end{array}$ \\
\hline
\end{tabular}

Gas Chromatography/Mass Spectrometry analytical data--Continued

$\begin{array}{lrrrrrr}\text { Propargite } & 135 & 79 & 7 & 155 & 17 & 31 \\ \text { Simazine } & 90 & 15 & 7 & 93 & 15 & 31 \\ \text { Tebuthiuron }^{\text {Terbacil }}{ }^{1} & 81 & 24 & 7 & 106 & 48 & 31 \\ \text { Terbufos }_{\text {Thiobencarb }} & 100 & 52 & 7 & 96 & 46 & 31 \\ \text { Triallate } & 92 & 12 & 7 & 114 & 27 & 31 \\ \text { Trifluralin } & 89 & 10 & 7 & 121 & 17 & 31 \\ & 93 & 15 & 7 & 110 & 12 & 31 \\ & 64 & 7 & 7 & 97 & 12 & 31\end{array}$

High-Performance Liquid Chromatography analytical data

\begin{tabular}{|c|c|c|c|c|c|}
\hline 1-Naphthol ${ }^{5,6,7}$ & 23 & 13 & 3 & 25 & 20 \\
\hline $2,4-\mathrm{D}$ & 51 & 15 & 7 & 64 & 20 \\
\hline 2,4-DB & 29 & 9 & 7 & 40 & 22 \\
\hline $2,4,5-\mathrm{T}$ & 68 & 25 & 4 & 82 & 26 \\
\hline $2,4,5-\mathrm{TP}^{6}$ & 60 & 12 & 7 & 73 & 23 \\
\hline 3-Hydroxy-carbofuran ${ }^{3,6}$ & -- & -- & 0 & 97 & 30 \\
\hline Acifluorfen ${ }^{3}$ & -- & -- & 0 & 71 & 24 \\
\hline Aldicarb $b^{6,7}$ & -- & -- & 0 & 93 & 32 \\
\hline Aldicarb sulfone $\mathrm{e}^{6,7}$ & -- & -- & 0 & 64 & 32 \\
\hline Aldicarb sulfoxide & 70 & 72 & 6 & 143 & 30 \\
\hline Bentazon & 51 & 16 & 7 & 72 & 26 \\
\hline Bromacil & 53 & 32 & 7 & 119 & 28 \\
\hline Bromoxynil & 52 & 11 & 7 & 77 & 24 \\
\hline Carbaryl $^{2,6,7}$ & -- & -- & 0 & 83 & 35 \\
\hline Carbofuran ${ }^{2,6}$ & 51 & 38 & 7 & 107 & 26 \\
\hline Chloramben $^{3}$ & - & -- & 0 & 74 & 24 \\
\hline Chlorothalonil ${ }^{3,5}$ & -- & -- & 0 & 19 & 14 \\
\hline Clopyralid $^{3}$ & -- & -- & 0 & 54 & 28 \\
\hline Dacthal, mono-acid ${ }^{3}$ & -- & -- & 0 & 70 & 28 \\
\hline Dicamba & 36 & 19 & 7 & 61 & 27 \\
\hline Dichlobenil 3,5 & -- & -- & 0 & 59 & 32 \\
\hline Dichlorprop & 56 & 12 & 7 & 76 & 26 \\
\hline Dinoseb & 51 & 17 & 7 & 71 & 20 \\
\hline Diuron & 50 & 23 & 7 & 84 & 27 \\
\hline DNOC $^{5}$ & 54 & 14 & 7 & 32 & 20 \\
\hline Esfenvalerate ${ }^{3,5}$ & -- & -. & 0 & 11 & 6 \\
\hline Fenuron & 50 & 31 & 7 & 105 & 22 \\
\hline Fluometuron & 53 & 28 & 5 & 104 & 24 \\
\hline Linuron $^{2}$ & 43 & 12 & 7 & 113 & 29 \\
\hline MCPA & 46 & 13 & 7 & 57 & 23 \\
\hline
\end{tabular}


Appendix A2--Summary of mean recoveries from field-matrix- and laboratory-reagent-spike pesticide analyses-Continued

\begin{tabular}{|c|c|c|c|c|c|c|}
\hline \multirow[b]{2}{*}{$\begin{array}{l}\text { Pesticide } \\
\text { target analyte }\end{array}$} & \multicolumn{3}{|c|}{ Field-matrix spikes } & \multicolumn{3}{|c|}{ Laboratory-reagent spikes } \\
\hline & $\begin{array}{l}\text { Mean } \\
\text { recovery } \\
\text { (percent) }\end{array}$ & $\begin{array}{l}\mathrm{SD} \\
\text { recovery } \\
\text { (percent) }\end{array}$ & $\begin{array}{l}\text { Number of } \\
\text { samples }\end{array}$ & $\begin{array}{l}\text { Mean } \\
\text { recovery } \\
\text { (percent) }\end{array}$ & $\begin{array}{l}\mathrm{SD} \\
\text { recovery } \\
\text { (percent) }\end{array}$ & $\begin{array}{l}\text { Number of } \\
\text { samples }\end{array}$ \\
\hline
\end{tabular}

High-Performance Liquid Chromatography analytical data--Continued

$\begin{array}{lrrrrrr}\text { MCPB }^{3} & -- & -- & 0 & 34 & 21 & 29 \\ \text { Methiocarb }^{6,7} & -- & -- & 0 & 100 & 31 & 17 \\ \text { Methomyl } & 45 & 25 & 7 & 109 & 25 & 29 \\ \text { Neburon } & 42 & 8 & 7 & 91 & 32 & 29 \\ \text { Norflurazon }^{3} & -- & -- & 0 & 101 & 31 & 27 \\ \text { Oryzalin }^{3} & -- & -- & 0 & 88 & 27 & 27 \\ \text { Oxamyl }^{6,7} & -- & -- & 0 & 82 & 31 & 24 \\ \text { Picloram }^{6} & 44 & 16 & 6 & 47 & 22 & 27 \\ \text { Propham }_{\text {Propoxur }}^{-} & 82 & 42 & 7 & 96 & 26 & 28 \\ \text { Triclopyr }^{3,6} & 34 & 17 & 7 & 123 & 28 & 15 \\ & -- & -- & 0 & 70 & 24 & 31\end{array}$

${ }^{1}$ Concentrations for these pesticides are qualitatively identified and reported with an E code (estimated value) because of problems with gas chromatography or extraction (Zaugg and others, 1995).

${ }^{2}$ Analyzed by both gas chromatography/mass spectrometry and high-performance liquid chromatography methods.

${ }^{3}$ Analyte not included in field-matrix spike mixture.

${ }^{4}$ Pesticide target analyte demonstrated small and variable recovery and was removed from the method schedule in November 1994.

${ }^{5}$ Pesticide target analyte selected for qualitative reporting or removal from method schedule based on poor overall recovery and precision (NAWQA/NWQL Quality Assurance Committee for the Schedule 2050/2051 Pesticide Analysis Method, written commun., 1995).

${ }^{6}$ Pesticide target analyte may degrade if spike mixture and/or sample is not kept chilled at less than 4 degrees Celsius.

${ }^{7}$ Field-matrix spike analyte selected for qualitative reporting based on poor overall recovery and precision. 